\title{
Observational studies of human endometrium and endometrial cancer : the role of steroids and steroid hormone receptors in tissue proliferation, differentiation and malignant transformation
}

Citation for published version (APA):

Mertens, H. J. (2002). Observational studies of human endometrium and endometrial cancer : the role of steroids and steroid hormone receptors in tissue proliferation, differentiation and malignant transformation. [Doctoral Thesis, Maastricht University]. Universiteit Maastricht. https://doi.org/10.26481/dis.20021128hm

Document status and date:

Published: 01/01/2002

DOI:

10.26481/dis.20021128hm

Document Version:

Publisher's PDF, also known as Version of record

Please check the document version of this publication:

- A submitted manuscript is the version of the article upon submission and before peer-review. There can be important differences between the submitted version and the official published version of record. People interested in the research are advised to contact the author for the final version of the publication, or visit the DOI to the publisher's website.

- The final author version and the galley proof are versions of the publication after peer review.

- The final published version features the final layout of the paper including the volume, issue and page numbers.

Link to publication

\footnotetext{
General rights rights.

- You may freely distribute the URL identifying the publication in the public portal. please follow below link for the End User Agreement:

www.umlib.nl/taverne-license

Take down policy

If you believe that this document breaches copyright please contact us at:

repository@maastrichtuniversity.nl

providing details and we will investigate your claim.
}

Copyright and moral rights for the publications made accessible in the public portal are retained by the authors and/or other copyright owners and it is a condition of accessing publications that users recognise and abide by the legal requirements associated with these

- Users may download and print one copy of any publication from the public portal for the purpose of private study or research.

- You may not further distribute the material or use it for any profit-making activity or commercial gain

If the publication is distributed under the terms of Article $25 \mathrm{fa}$ of the Dutch Copyright Act, indicated by the "Taverne" license above,

Download date: 26 Apr. 2023 


\section{Observational studies of human endometrium and endometrial cancer}

The role of steroids and steroid hormone receptors

in tissue proliferation, differentiation and malignant transformation

H.J.M.M. Mertens 
ISBN 90-9016377-8

Cㄱ H.J.M.M. Mertens, Maastricht, 2002

Illustraties: Tom Eyzenbach

De illustratie symboliseert voor mij mijn promotieonderzoek.

Onder invloed van het brein vinden cyclische veranderingen plaats in het kleine bekken van de vrouw. Bij vrouwen met een endometriumcarcinoom is dit milieu relatief rijk aan mannelijke hormonen. Steeds werd een verschillend aspect van het endometrium onder de loep genomen. 


\section{Observational studies of human endometrium and endometrial cancer}

The role of steroids and steroid hormone receptors in tissue proliferation, differentiation and malignant transformation

\section{PROEFSCHRIFT}

ter verkrijging van de graad van doctor aan de Universiteit Maastricht,

op gezag van de Rector Magnificus,

Prof. dr. A.C. Nieuwenhuijzen Kruseman

volgens het besluit van het College van Decanen,

in het openbaar te verdedigen

op donderdag 28 november 2002 om 12.00 uur

door

Helena Josephina Maria Mathea Mertens

geboren op 16 april 1969

te Heerlen 


\section{promotores}

Prof. dr. J.L.H. Evers

Prof. dr. M.J. Heineman (Rijksuniversiteit Groningen)

co-promotor

Dr. M. Nap (Atrium medisch centrum Heerlen)

beoordelingscommissie

Prof. dr. M.F. von Meyenfeldt (voorzitter)

Prof. dr. J.G. Aalders (Rijksuniversiteit Groningen)

Prof. dr. M.J.A.P. Daemen

Prof. dr. D.G. Kieback

Prof. dr. J.J.H. Thijssen (Universiteit Utrecht) 
aan mijn ouders

uit dankbaarheid 


$$
\longrightarrow
$$




\section{Contents}

Abbreviations $\quad 3$

Chapter 1

General introduction

Chapter 2

Androgen, estrogen and progesterone receptor expression in the human uterus during the menstrual cycle

Chapter 3

The expression of apoptosis related proteins $\mathrm{BCl}-2$ and $\mathrm{Ki} 67$

in endometrium of ovulatory menstrual cycles

\section{Chapter 4}

Steroid hormone receptor analysis in human endometrium: comparison of immunohistochemistry and flow cytometry

\section{Chapter 5}

Multiparameter flowcytometry in the diagnosis of a gynaecologic double tumor: a case report

\section{Chapter 6}

Steroids in postmenopausal women with and without endometrial cancer

\section{Chapter 7}

Steroid receptor content and its heterogeneity in relation to

DNA ploidy in benign and malignant endometrium

\section{Chapter 8}

Serum and tissue levels of apoptosis and proliferation markers

in relation to DNA ploidy in benign and malignant endometrium

\section{Chapter 9}

General discussion

Chapter 10

Summary

Samenvatting

Dankwoord

Curriculum vitae 



\section{Abbreviations}

\begin{tabular}{|c|c|}
\hline A & androstenedione \\
\hline $\mathrm{Ag}$ & antigen \\
\hline AR & androgen receptor \\
\hline BrdU & 5-bromo-2'-deoxyuridine \\
\hline BSA & bovine serum albumin \\
\hline CK & cytokeratin \\
\hline DHEA & dehydroepiandrosterone \\
\hline DHEAS & dehydroepiandrosterone sulphate \\
\hline DHT & dihydrotestosterone \\
\hline DNA & deoxyribunucleic acid \\
\hline$E_{1}$ & estron \\
\hline E2 & $17 \beta$-estradiol \\
\hline E3 & estriol \\
\hline EP & early proliferative phase \\
\hline ER & estrogen receptor \\
\hline ES & early secretory phase \\
\hline MP.FCM & flow cytometry \\
\hline FIGO & International Federation of Gynecology and Obstetrics \\
\hline FITC & fluorescein isothiocyanate \\
\hline ICC & intraclass correlation coefficient \\
\hline $\lg$ & immunoglobulin \\
\hline IH & immunohistochemistry \\
\hline kD & kilodalton \\
\hline LP & late proliferative phase \\
\hline LS & late secretory phase \\
\hline M & menstruation phase \\
\hline MMP & matrix metalloproteinase \\
\hline MoAb & monoclonal antibody \\
\hline MPF & multiparameter flowcytometry \\
\hline MS & mid secretory phase \\
\hline $\mathrm{n}$ & nano \\
\hline $\mathrm{m}$ & milli \\
\hline $\mathrm{p}$ & pico \\
\hline$P$ & postmenopause \\
\hline PBS & phosphate-buffered saline \\
\hline PR & progesterone receptor \\
\hline $\begin{array}{l}r \\
\text { RFI }\end{array}$ & Pearsons' (product moment) correlation coefficient \\
\hline $\begin{array}{l}\text { RFI } \\
\text { RPE }\end{array}$ & relative fluorescence intensity \\
\hline RPE & r-Phycoerytrein \\
\hline SD & standard deviation of a set of observations \\
\hline SHBG & sex hormone binding globuline \\
\hline T & testosterone \\
\hline $\mathbf{U}$ & units \\
\hline$\mu$ & mu \\
\hline$\Sigma$ & sum of \\
\hline
\end{tabular}



CHAPTER 1

General introduction

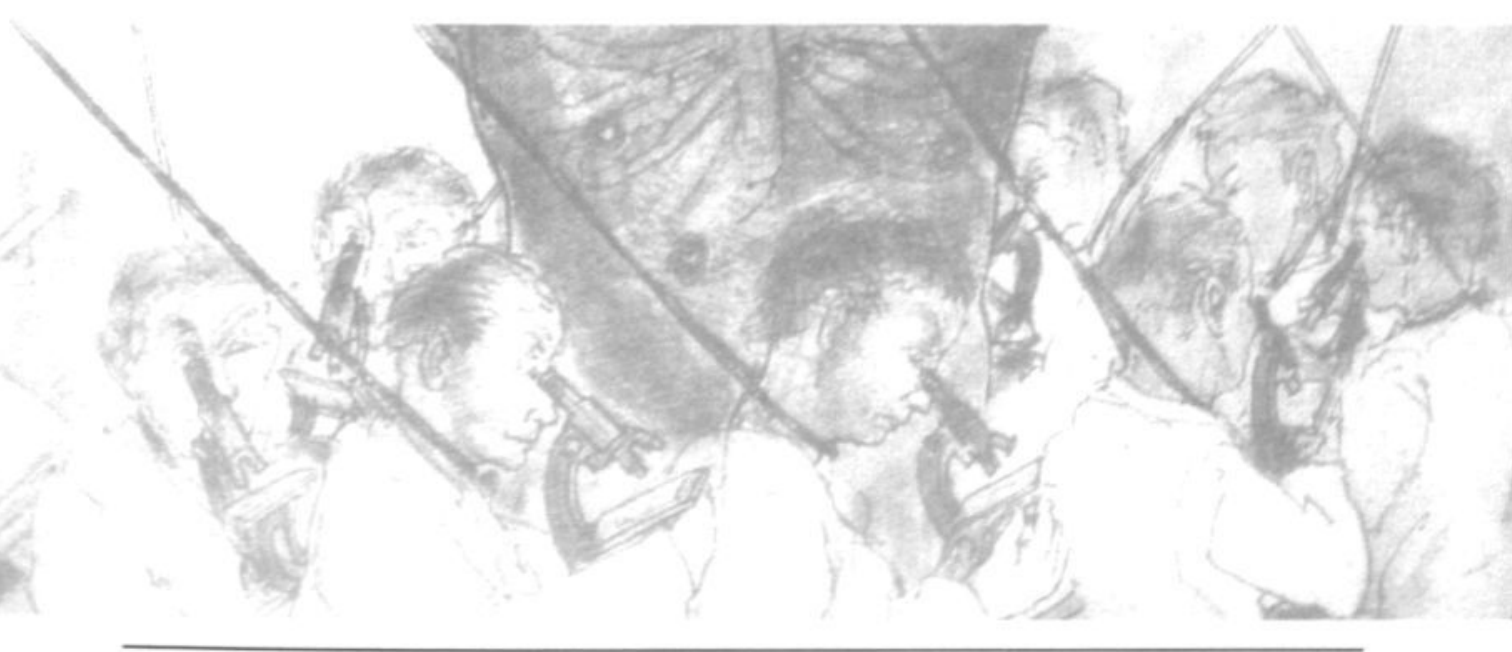




\section{Introduction}

During the reproductive years of life, steroid hormones govern the cyclic changes of endometrium. Endometrial histomorphology is characterized by function-related changes of both glandular and stromal cells and by a remarkable sensitivity to steroid hormones and an amazing regenerative capacity for restoration after menstrual sloughing. The functional and morphologic changes of premenopausal endometrium are summarized as regeneration, proliferation, secretory differentiation, predecidualization and menstruation $(1,2)$; postmenopausal endometrium is mostly atrophic but may occasionally be hyperplastic. Many endometrial disorders in the preas well as in the postmenopause have been suggested to result from dysregulation of steroid modulated expression of growth factors and angiogenic factors (3).

\subsection{Steroid hormones}

The molecular structure of all steroid hormones is basically the same, the number of carbon atoms differs: progesterone (and corticosteroids) consists of 21 carbon atoms, androgens consist of 19 carbon atoms and estrogens consist of 18 carbon atoms (2). The primary sources of natural sex steroid hormones are the ovaries. Gonadal theca and granulosa cells form androgens (in premenopause mainly in response to Luteinizing hormone (LH)) and estrogens (in response to Follicle-stimulating hormone (FSH)) $(2,4-5)$. The luteinized granulosa cells of the corpus luteum produce progesterone and estradiol (in response to LH) $(2,4)$.

Androgens are the common precursors for estrogens: they will be aromatized to estrogens in granulosa cells $(2,6)$, in peripheral fat, nervous and muscle tissue and endometrium (2). Testosterone ( $T$ ) can be aromatized to $17 \beta$-estradiol ( $E_{2}$ ). Androstenedione (A) can be aromatized (via estrone ( $\left.E_{1}\right)$ to $E_{2} ; E_{1}$ can also be converted to estriol $\left(E_{3}\right)$. In the liver, $E_{1}$ and $E_{3}$ are formed from $E_{2}$. Peripheral conversion of steroids to progesterone $(P)$ is not seen in non-pregnant women (2). Aromatization is mediated by $\mathrm{P}_{450}$ aromatase that is present in the endoplasmic reticulum (2). The non- $\mathrm{P} 450$ aromatase reactions are mediated by $17 \beta$-hydroxysteroid dehydrogenase and the $5 \alpha$-reductase reactions. The $17 \beta$-hydroxysteroid dehydrogenase enzyme converts $E_{1}$ to $E_{2}, A$ to $T$, dehydroepian-drosterone (DHEA) to androstenediol (2). The $5 \alpha$-reductase enzyme converts T to dihydrotestosterone (DHT) $(2,4)$.

$E_{2}$ is formed after aromatization of $T$ and $A$ via $E_{1} . T$ derives from three sources: from the adrenal glands and the ovaries and from the peripheral conversion of the prehormones A and DHEA (7). Actions of androgens arise from intracellular conversion of $\mathrm{T}$ to $\mathrm{DHT}$; from T itself; or from intracellular conversion of $\mathrm{T}$ to $E_{2}$ (2).

After menopause, the production of estrogens and P decreases since the process of follicular growth has come to an end. Studies on the endocrine activity of postmenopausal ovaries have shown little residual estrogen and progesterone production; most estrogens are formed by extragonadal conversion of androgens $(2,4,8)$. In contrast, postmenopausal ovaries continue to be a source of other sex 
steroid hormones: they produce small amounts of $E_{1}, T$ and $A$. $T$ and $A$ are the major steroid hormones produced by the postmenopausal ovary (9), but the circulating level of $A$ is only about half the level which is determined in premeno-pausal years (2). $E_{1}$, $A$ and $T$ are converted peripherally to $E_{2}(2,10)$

The most potent estrogen is E2. Compared to this steroid, estron ( $\left.E_{1}\right)$ is about $20 \%$ and estriol ( $\left.E_{3}\right)$ about $5 \%$ as active (11). $E_{1}$ is the predominant estrogen after menopause. Testosterone ( $\mathrm{T}$ ) and dihydrotestosterone (DHT) are the most potent androgens. When the relative activities of the specific androgens are compared, large differences are found, mainly caused by differences in the metabolism of androgens in the different tissues (12). Most of the circulating testosterone is bound to transport proteins whereas only a small percentage biologically is active as the unbound fraction. SHBG is the major transport protein. True androgen status can be assessed with the help of the ratio of the total testosterone concentration to the concentration of sex hormone binding globulin (SHBG), i.e. the free-androgen-index (7).

Figure 1 The two-cell, two-gonadotrophin concept of sex steroid synthesis

Androgen synthesis in thecacells, estrogen synthesis in granulosacells and aromatization (**).

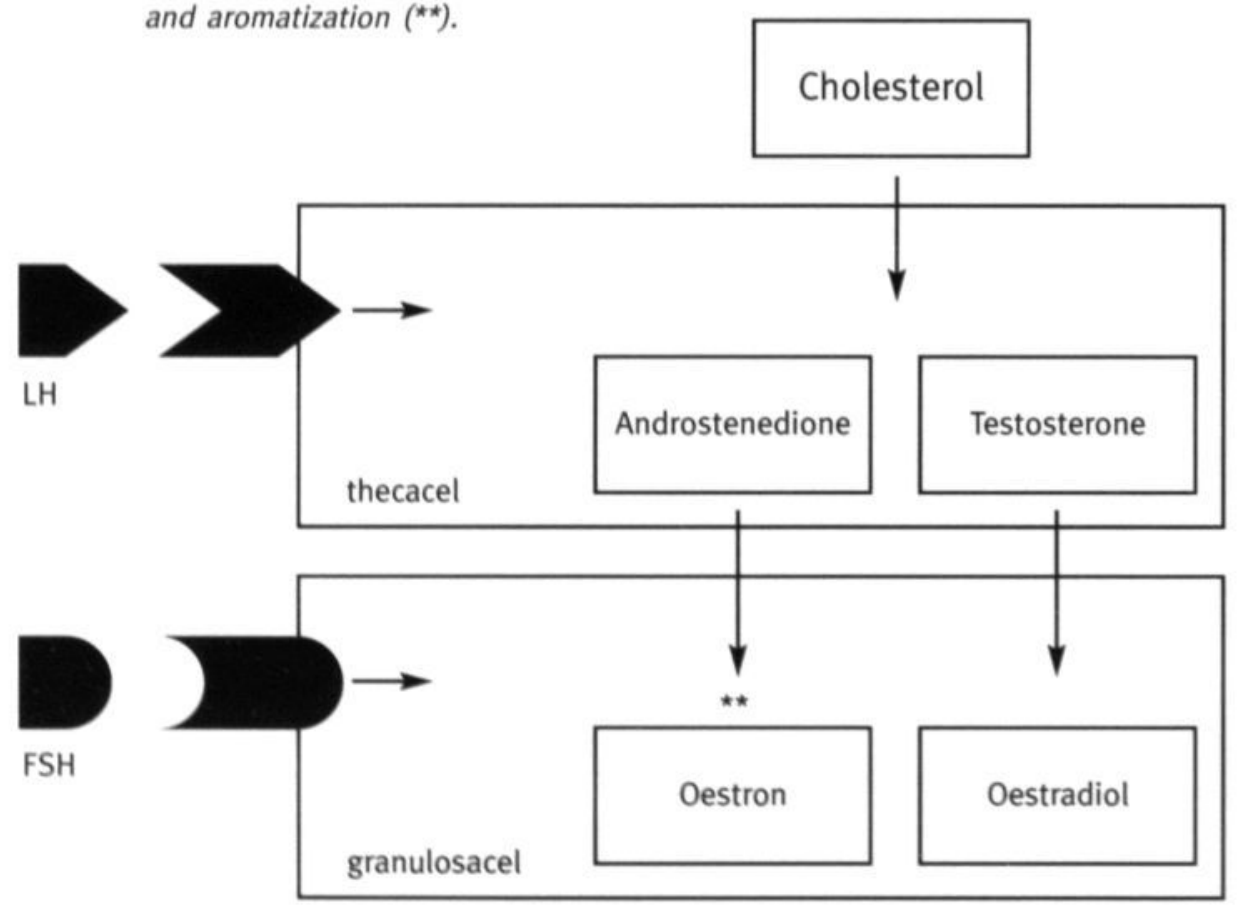

\subsection{Steroid receptors}

The action of the steroid hormones is determined by the structure of the hormone, the (subtype of the) steroid hormone receptor and the balance of promoting and inhibiting effects. General mechanisms of steroid hormone reactions rely on the presence of specific intranuclear receptor proteins (2). Binding of a steroid to its 
specific receptor alters the receptor structure in a transcription modulating state, which results in the production of messenger RNA (mRNA). This in turn leads to either the synthesis or the inhibition of cellular proteins with their specific cellular activity (2).

The estrogen receptor (ER) and progesterone receptor (PR) have two subtypes ( $\alpha$ and $\beta$ ) characterized by a different length of the chain of amino acids. Both have different functional characteristics. The ER $\alpha$ is a single polypeptide chain of 595 amino acids, and $E R \beta$ of 485 amino acids, with molecular weights of 66-70 kiloDaltons (kDa) and 58-62 $k D a$ respectively $(13,14)$. ER binds $E_{2}$ with high affinity, whereas $E_{1}$ and $E_{3}$ display approximately $1 / 10$ of this binding affinity $(2,11)$. Saegusa and coworkers reported that the amount of ER $\alpha$ at both mRNA and protein levels was significantly higher than the amount of ER $\beta$ in normal and malignant endometrium (15). ER $\alpha$ mRNA showed a stepwise decrease from normal endometrium via grade 1 to grade 3 tumor lesions, in contrast to ER $\beta$ mRNA or protein expression, which did not alter.

The $P R \alpha$ is a protein of 769 , and PR $\beta$ a protein of 933 amino acids with molecular weights of 94 and $114 \mathrm{kDa}$ respectively (16). Progesterone binds to the complete receptor with high affinity, but the resultant complex dissociates rapidly. Both $P R \alpha$ and PR $\beta$ are differentially expressed in human endometrium.

The androgen receptor (AR) is a protein of 910-919 amino acids with a molecular weight of 99-110 kD (17-19). Sequence comparison of AR with the structure of other steroid receptors demonstrates a highly conserved DNA-binding domain (amino acid 557-621). Regions in the $\mathrm{COOH}$-terminus of the protein reveal significant homology with other steroid receptors (amino acid 704-746 and 790-812); the N-terminal region of the AR is a region with low homology with other steroid receptors $(18,20)$. Although the presence of AR is present in many human tissues, little is known about the AR content of human (cyclic) endometrium.

Steroid hormones regulate the expression of steroid receptors: estrogens increase the concentration of intracellular ER, PR and AR (2-3). Progesterone on the other hand, blocks replenishment of ER and PR. The AR content is correlated with the content of $E R$ and $P R$. The progestin medroxyprogesterone acetate for example, inhibits the proliferation of ER and PR via the AR.

\subsection{Steroid Receptor analysis}

Many methods of ER and PR determination have been described. Radiochemical steroid receptor assays and many immunohistochemical assays (using anti-steroid antibodies, autofluorescent antibodies, autofluorescent ligands, directly fluorochromated ligands, monoclonal antibodies or computer-assisted image analysis) permit analysis in the different histomorphological layers of tissue. Radioligand binding assays do not provide information about intra- and intercellular distribution of receptors.

The main advantage of the immunohistochemical assays is their ability to visualize receptors in individual cells and to quantify them in tissue sections with preservation of histomorphology. Furthermore, it allows receptor determination in very small tissue samples. The introduction of molecular biological techniques has allowed new 
concepts to be used in the establishment of the diagnosis and prediction of tumor behavior. Quantification of cell biological parameters by computer-assisted image analysis, such as flow cytometric steroid receptor assays, can be important as a method for steroid receptor analysis. In chapter 4 the development of this assay to quantify steroid receptor content more accurately in an endometrial epithelial cell population will be addressed.

\subsubsection{Immunohistochemical receptor analysis}

Monoclonal antibodies have been successfully applied to the immunocytochemical detection of ER, PR and AR in fresh frozen uterine sections and in sections of paraffin embedded tissue. In chapter 2 steroid receptor content will be described in different phases of the menstrual cycle in stromal and glandular epithelial cells of the endometrium and of the myometrium, as detected by immunohistochemistry.

\subsubsection{Flow cytometric receptor analysis}

Steroid receptor content in human endometrium can be quantified by multiparam-eter flow cytometry. After preparation of a cell suspension, the cells retain enough cytoskeletal remnants to allow immunocytochemical detection of the cytokeratins. Labeling of the cytokeratins can be used to restrict the flow cytometric analysis to the epithelial compartment of the tissue.

The flow cytometric analysis of immunofluorescence staining for steroid receptors in premenopausal and normal postmenopausal endometrium will be shown in chapter 4 . In the same endometrium samples, steroid receptor content is detected by immunohistochemistry. Multiparameter flow cytometric analyses will be described in chapter 7 and 8 .

\subsection{Steroid hormones and physiological endometrial effects}

The human endometrium can be divided morphologically into an upper two-thirds 'functionalis' and a lower one-third 'basalis' layer. The purpose of the functionalis layer is to prepare for the implantation of the blastocyst and, therefore, it is the site of proliferation, secretion and degeneration. The purpose of the lamina basalis is to provide the regenerative endometrium following menstrual loss of the lamina functionalis.

The sequence of endometrial changes associated with an ovulatory menstrual cycle has been described by Noyes and coworkers (1). Markee studied endometrial changes in intraocular transplants (20-21). He described cyclic endo-metrial growth changes, especially associated vascular changes, including buckling of the coiled arteries, vascular stasis, necrosis, vasoconstriction and ischaemia. Desquamation, in his view, was associated with focal necrosis and decrease of endometrial thickness due to the disappearance of stromal edema, induced by local changes (22).

\subsubsection{Premenopausal endometrium}

In the course of the menstrual cycle, ovarian production of $17 \beta$-estradiol increases, which will lead to proliferation of stromal and epithelial cells of the endometrium. The denuded basal endometrial surface is re-epithelialised within three to seven days following the beginning of menstruation. In the proliferative phase, the endometrium 
increases in thickness, owing to increasing numbers of stromal cells and the progressive growth of the endometrial glands and blood vessels in the endometrium. After ovulation, progesterone and estrogens are secreted in large amounts by the corpus luteum. The estrogens cause slight additional cellular proliferation in the endometrium, whereas progesterone causes marked swelling and secretory development of the endometrium. The glands increase in tortuosity and secretory substances accumulate in the glandular epithelial cells. Also the cytoplasm of the stromal cells increases. The blood supply to the endometrium increases in proportion to the developing secretory activity.

The whole purpose of endometrial changes is to produce a highly secretory endometrium containing large amounts of stored nutrients, providing appropriate conditions for implantation of a fertilized ovum.

Approximately two days proceeding the menstrual period the corpus luteum involutes and the secretion of ovarian hormones decreases. With the decrease of estrogens and progesterone, the endometrial cell stimulation ceases.

Progesterone withdrawal causes an increase of the metalloproteinases (MMP) production. The MMP's separate the functional from the basal endometrial layer and the outer (still vital) superficial layers of the endometrium are desquamated.

Physiological and pathological effects induced by steroid hormones vary between the various cells of the human endometrium and myometrium. The mechanisms of steroid interactions and their effect on the individual endometrial tissue compo-nents are still unclear. Interaction between stromal and epithelial cells is essential in normal growth and function during the various phases of the menstrual cycle. Steroids also may be involved in the process of endometrial carcinogenesis. To understand the endocrine mechanisms in endometrial (patho-) physiology, steroid receptor determination should preferentially be studied at the cellular level.

\subsubsection{Postmenopausal endometrium}

Postmenopausal endometrium is still sensitive to steroids. In the absence of steroids however, it may undergo atrophic changes, like the other genital tract tissues. The endometrium becomes thin, the surface and glandular epithelial cells appear low cuboidal in type, and the glands become very sparse and shallow. Sometimes, for as yet unknown reasons, the glands may become cystic.

The character of the hormonal transition from the menstruation phase to the postmenopause exhibits wide variation among women. For example, the terminal menstrual cycles are sometimes ovulatory but very often anovulatory; in the latter group the endometrium often shows a hyperplastic pattern due to unopposed estrogen activity.

With the onset of menopause, the growth stimulus ceases. The stromal cells regress and may ultimately become fibrotic. The epithelial cells no longer exhibit mitotic evidence of active growth. Many of the glands remain large and cystic. Postmenopausal endometrium varies in degree of its sensitivity or its refractoriness to the steroid stimulus and variations in histology are often seen in different parts of the same endometrium.

Certain forms of atypical hyperplasia are characterized by tall pale-staining epithelial cells with varying degree of intraluminal budding and tufting. It may be difficult to distinguish this hyperplastic endometrium from a genuine secretory endometrium, 
although hyperplastic epithelium is generally thicker than secretory endometrium and there are no predecidual changes in its stromal cells.

Summarizing observations in postmenopausal endometrium, the following variations may be found: (1) a thin, atrophic mucosa; (2) a mucosa of varying thickness, showing focal patterns of hyperplasia of the inactive, retrogressive type, with many of the glands distended, and others small and atrophic; and (3) an active hyperplastic mucosa, either diffuse or in scattered patches, large or small and not infrequently polypoid. At the same time, various combinations of these patterns may be seen in different parts of the endometrium.

\subsection{Steroid hormones and pathologic endometrial effects}

Steroid hormones are also related to malignant proliferation of the endometrium. Both exogenous and endogenous steroids may affect the process of endometrial function and morphology and of endometrial carcinogenesis. Increased prolifer-ation is an estrogen-induced effect. Progesterone effects are characterized by modulation of the growth-stimulatory effects of estrogens, cellular differentiation and atrophy. Also androgens have been suggested to have an impact on the physiological and pathological changes within the endometrium. Brody and coworkers concluded that the adrenal androgens might affect the endometrium via peripheral conversion to estrogens and via direct interaction with endometrial androgen receptors (23).

Abnormal endometrial proliferations form a morphologic continuum ranging from focal glandular crowding through various degrees of hyperplasia to carcinoma. Classifications have been developed in which degrees of proliferation are separately labeled. Proliferation composed of closely packed complex glands displaying cytologic atypia provides difficulty in interpretation since some carcinomas lack atypia and some hyperplasias show atypia.

Cystic hyperplasia is the most common form of hyperplasia and is characterized by dilated glands of varying sizes lined by tall columnar or cuboidal epithelium. Adenomatous hyperplasia has been studied by many different authors. They described widely differing patterns $(24-26)$. Especially glandular changes have been found. Atypical hyperplasia is proliferative endometrium characterized by a greatly increased number of glands with very little intervening stroma.

\subsection{Endometrial cancer}

\subsubsection{Histologic characteristics}

The gross appearance of the various types of endometrial cancer shows a rough endometrial surface with focal hemorrhagia. Necrosis is unusual in well-differentiated carcinomas, but may be seen in poorly differentiated tumors. Myometrial invasion appears as a well-demarcated exophytic mass within the uterine wall.

Endometrial cancers are divided in endometroid, serous, squamous, clear cell and mucinous carcinoma. Besides the microscopic appearance, clinical aspects, tumor behavior, steroidal influences and patient prognosis are different. 


\subsubsection{Clinical characteristics}

In 10-20\% of patients with postmenopausal bleeding this is caused by malignancies of the female genital tract; the majority of these concerns endometrial cancer. It is the most common gynaecologic malignancy in developed countries in women between 50-70 years of age (27).

Although endometrial cancer is characteristically a disease of postmenopausal women, it may be seen before menopause: metrorrhagia may generally be indicative of endometrial cancer. With increasing age it will be more likely that postmenopausal bleeding is due to endometrial cancer.

Endometrial cancer can be subclassified according to the Grade (low, intermediate or high grade) or the FIGO-stage of the disease (Table 1). A high Grade of tumor and a high stage of disease are associated with poor prognosis and with metastatic spread.

\subsection{Proliferation Markers}

In the recent decade, investigators have tried to obtain insight into the proliferative compartment of a tumor. The use of immunohistochemical techniques enables the visualization of specific, cell cycle-related antigens. There are several developments in this area: a number of antibodies have become available which recognize proliferation-associated antigens, like Ki67.

$\mathrm{Ki67}$ is widely used as a marker substance for the immunohistochemical determination of cycling cells (28). It is a monoclonal antibody reacting with a large nuclear, non-histone protein doublet of 395 and $345 \mathrm{kD}$, present in the cell cycle at late $\mathrm{G}_{1}$, $\mathrm{S}, \mathrm{G}_{2}$ and mitosis, but it is absent in the $\mathrm{Go}_{0}$ and early $\mathrm{G}_{1}$ (29-30). Several studies have shown a good correlation between $\mathrm{Ki} 67$ immunoreactivity and other indices of cell proliferation (31-33).

S-phase fraction (SPF) is widely used as a proliferation marker in flow cytometric studies. In the S-phase, the cells replicate their DNA. The proportion of cells in the S-phase of the cell cycle reflects tumor proliferation. The SPF of tumor tissue predicts the clinical behavior of human tumors (34). The SPF of normal, hyperplastic and malignant endometrium will be analyzed using multiparameter flow-cytometry.

\subsection{Apoptosis}

For homeostatic tissue growth, a delicate balance must be maintained between proliferation and cell death. In contrast to necrosis, which is a non-physiological way of cell death caused by e.g. toxic insults, apoptosis is a normal physiological process of cell death. It is involved in normal tissue renewal, metamorphosis, embryogenesis and hormone induced atrophy. It is also involved in endometrial changes within the normal menstrual cycle.

During apoptosis, cells shrink and dissociate from surrounding cells, organelles remain functional, the plasma membrane shows lipid asymmetry and eventually loss of integrity, and the nucleus displays a distinctive pattern of heterochromatization and eventual fragmentation.

Physiologic cell death relies on processes that can be modulated by extra-cellular stimuli, like steroid hormones. Abnormalities in apoptosis regulation may contribute to the pathogenesis of neoplasms (35). The occurrence of apoptosis is associated 
with tumors of a higher grade in hormone-dependent epithelial tumors, like endometrial cancer. A possible explanation for apoptosis in tumors is the increased sensitivity to apoptosis of cells that have lost their matrix attachment or cell-cell contacts. This could be due to a loss of expression of cell adhesion molecules from the surface of neoplastic cells.

Bcl-2 promotes cell survival by preventing apoptosis. Bcl-2 expression can be determined using immunohistochemistry (36) and flowcytometry (37); it is widely used as a marker of apoptosis, because overexpression of Bcl-2 pointed out to block apoptosis (38-40).

The monoclonal antibody $M_{30}$ recognizes apoptotic epithelial cells at cytoskeleton level, i.e. by identification of a caspase cleavage site in cytokeratin (CK) 18 (41). This neo-epitope is exposed only during (early) apoptosis. In late apoptosis, when cells become necrotic, the $M_{30}$ neo-epitope is lost (42). The M30 marker allows quantification of early apoptosis and can be used to study the dynamic process of induction and inhibition of natural cell deaths. It can be detected in blood serum and in tissue.

We will investigate $\mathrm{Bcl}-2$ and $\mathrm{M}_{3}$ expression in postmenopausal normal endometrium, in endometrial hyperplasia and in endometrial cancer. Besides, we will investigate $\mathrm{M}_{30}$ serum concentrations in patients with and patients without endometrial cancer.

\subsection{Ratio and aim of the present study}

The steroid receptor content in the various cells of the endometrium and myometrium suggests potential responsiveness to the particular steroid hormones. The relative proportion of steroid receptors and their interactions with their specific steroids determine the expression of specific genes upon steroidal stimulation.

The analysis of ER, PR and AR content may yield more specific information on the local hormonal relationship involved in normal endometrial physiology. The aim of the first part of the present study is to investigate mechanisms involved in normal hormone dependent physiological tissue remodeling: we will investigate steroid receptor content, $\mathrm{Ki} 67$ expression as a proliferation marker, and $\mathrm{Bcl}-\mathbf{2}$ expression as an apoptosis marker in human cyclic endometrium and myometrium.

Previous studies have concluded that postmenopausal ovaries produce significant amounts of A en T, in contrast to only small amount of estrogens (9). The question arises whether these androgens play a (direct) role in the etiology of endometrial cancer. We will investigate steroid hormone concentrations in peripheral and uteroovarian veins in patients with and patients without endometrial cancer.

\section{Aims of this thesis summarized:}

Aim 1: to document the expression of ER, PR, AR, Bcl-2 and $\mathrm{Ki} 67$ in cyclic human endometrium and myometrium

Aim 2: to study the peripheral and pelvic endocrine milieu in patients with and without endometrial cancer

Aim 3: to document the expression of ER, PR, AR, M30, SPF and DNA-ploidy in postmenopausal inactive endometrium, in hyperplastic endometrium and in 
endometrial cancer

Aim 4: to investigate the role of multiparameter flow cytometry for studying ER, PR and $A R$ in pre- and postmenopausal endometrium

\section{References}

1 Noyes RW, Herig AT, Rock J. Dating endometrial biopsy. Fertil Steril 1950; 1: 3-10

2 Speroff L, Glass RH, Kase NG. Clinical Gynecologic Endocrinology and infertility, $5^{\text {th }}$ ed. Williams \& Wilkins 1994

3 Oehler MK, Rees MC, Bicknell R. Steroids and the endometrium. Curr Med Chem 2000; 7: 543.560

4 Gruber CJ, Tschugguel W, Schneeberger C, Huber JC. Production and actions of estrogens. N Eng I Med 2002; 346: 340-352

5 Lieberman S. Are estradiol-producing cells incompletely endowed? A chronicle of the emergence of certitude from conjecture. Gynecol Obstet Invest 1996; 41: 147-172

6 Hillier SG, Whitelaw PF, Smyth CD. Follicular oestrogen synthesis: the two-cell, two-gonadotropin model revisited. Mol Cell Endocrinol 1994; 100: 51-54

7 Vankrieken L. Testosterone and the Free Androgen Index, 1997; 5

8 Meldrum DR, Davidson BJ, Tataryn IV, Judd HL. Changes in circulating steroids with aging in postmenopausal women. Obstet Gynecol 1981; 57: 624-628

9 Sluijmer AV, Heineman MJ, de Jong FH, Evers JLH. Endocrine activity of the postmenopausal ovary: the effects of pituitary down-regulation and oophorectomy. J Clin Endocrinol Metab 1995; 80: 2163-2164

10 Siiteri PK. Postmenopausal estrogen production. In: van Keep PA, Lauritzen C, eds. Front Hormone Res (Karger, Basel) 1975; 3: 40-5

11 Collins WP. Ovarian steroid hormones. In: Scientific Foundations of Obstetrics and Gynaecology, $3^{\text {rd }}$ ed. Elliot P, Barnes J \& Newton M, eds. London, Heinemann Medical Books 1987: 465-472

12 Jong de FH. Secretion and production of androgens. In: Androgenen en antiandrogenen 1982

13 Green S, Walter P, Kumar V, Krust A, Bornert JM, Argos P, Chambon P. Human oestrogen receptor CDNA: sequence, expression and homology to v-erbA. Nature 1986, 320: 134-139

14 Pavao M, Traish AM. Estrogen receptor antibodies: specificity and utility in detection, localization and analyses of estrogen receptor $\alpha$ and $\beta$. Steroids 2001; 66: 1-16

15 Saegusa M, Okayasu I. Changes in expression of estrogen receptors in alpha and beta in relation to progestrone receptor and pS2 status in normal and malignant endometrium. Ipn J Cancer Res 2000; 5: 510-518

16 Misrahi M, Atger M, d'Auriol L, Loosfelt H, Meriel C, Fridlansky F, GuiochonMantel A, Galibert F, Milgrom E. Complete amino acid sequence of the human progesterone receptor deduced from cloned cDNA. Biochem Biophys Res Comm 1987, 143: 740-748

17 Lubahn DB, Joseph DR, Sar M, Tan J, Higgs HN, Larson RE, French FS, Wilson EM. The human androgen receptor: complementary deoxyribonucleic acid cloning, sequence analysis and gene expression in prostate. Mol Endocrinol 
1988, 2: $1265-1275$

18 Faber PW, Kuiper GGJM, van Rooij HC), van der Korput HA, Baarends WM, Brinkmann AO, Grootegoed JA, Trapman J. Characterization of the human androgen receptor. Birkhauser Congress Reports. Life Sciences, 1989, 40: 169-181

19 Trapman J, Klaassen P, Kuiper GGJM, van der Korput JA, Faber PW, van Rooij HC, Geurts van Kessel A, Voorhorst MM, Mulder E, Brinkmann AO. Cloning, structure and expression of a cDNA encoding the human androgen receptor. Biochem Biophys Res Commun 1988, 153: 241-248

20 Wilson CM, McPhaul MJ. A and B forms of the androgen receptor are expressed in a variety of human tissues. Mol Cell Endocrinol 1996; 120: 51-57

21 Markee JE. Menstruation in intraocular endometrial transplants in the rhesus monkey. Obstet Gynecol 1978; 131: 558-559

22 Markee JE. Am J Physiol 1932; 100: 32

23 Brody S, Carlstrom K, Uexkull von AK, Lagrelius A, Lunell NO, Rosenborg L. Peripheral hormone levels and the endometrial condition in postmeno-pausal women. Acta Obstet Gynecol Scand 1983; 62: 525.529

24 Bergeron C, Nogales FF, Masseroli M, Abeler V, Duvillard P, Muller-Holzner E, Pickartz $\mathrm{H}$, Wells $\mathrm{M}$. A multicentric European study testing reproducibility of the WHO classification of endometrial hyperplasia with a proposal of a simplified working classification for biopsy and curettage specimens. Am J Surg Pathol 1999; 23: 1102-1108

25 Mutter GL, Baak JPA, Crum CP, Richart RM, Ferency A, Faquin WC.

Endometrial precancer diagnosis by histopathology, clonal analysis, and computerized morphometry. J Pathol 2000; 190: $462-469$

26 Mutter GL. Diagnosis of premalignant endometrial disease. J Clin Pathol 2002; 55: $326 \cdot 331$

27 Visser O, Coebergh JWW, Schouten LJ, van Dijck JAAM. Incidence of cancer in the Netherlands 1997. Netherlands Cancer Registry, VIKC 2001

28 Gerdes J, Schwab U, Lemke H, Stein H. Production of mouse monoclonal antibody reactive with a human nuclear antigen associated with cell proliferation. Int J Cancer 1983; 31: 13-20

29 Gerdes J, Lemke H, Baisch H, Wacker HH, Schwab U, Stein H. Cell cycle analysis of a cell proliferation-associated human nuclear antigen defined by the monoclonal antibody Ki67. J Immunol 1984; 133: 1710-1715

30 Gerdes I, Li L, Schlueter C, Duchrow M, Wohlenberg C, Gerlach C, Stahmer I, Kloth S, Brandt E, Flad HD. Immunobiochemical and molecular biological characterization of the cell proliferation-associated nuclear antigen that is defined by monoclonal antibody Ki67. Am J Pathol 1991; 138: 867-873

31 Baisch J, Gerdes J. Simultaneous staining of exponentially growing versus plateau phase cells with the proliferation-associated antibody $\mathrm{Ki}_{7} 7$ and propidium iodide: analysis by flow cytometry. Cell Tissue Kinet 1987; 20: 387-391

32 Schwarting R, Gerdes J, Niehus J, Jaeschke L, Stein H. Determination of the growth fraction in cell suspensions by flow cytometry using the monoclonal antibody Ki67. J Immunol Methods 1986; 90: 365-371

33 Walker RA, Camplejohn RS. Comparison of monoclonal antibody Ki67 reactivity with grade and DNA flow cytometry of breast carcinomas. Br J Cancer 1988; 57 : $281-283$ 
34 Bauer KD, Duque RE, Shankey TV (eds). Clinical flow cytometry, principles and application. Baltimore, Williams and Wilkins, 1993

35 Soini Y, Paakko P, Lehto VP. Histopathologic evaluation of apoptosis and $\mathrm{BCl}-2$ in human solid neoplasms. Cytometry 1995; 20:154-163

36 Joensuu H, Pylkkanen L, Toikkanen S. Bcl-2 protein expression and long term survival in breast cancer. Am J Pathol 1994: 145: 1191-1198

37 Steck KD, McDonnel TJ, El-Naggar AK. Flow cytometric analysis of apoptosis and Bcl-2 in human solid tumor neoplasms. Cytometry 1995; 20: 154-163

38 Steck KD, McDonnel T), Sneige N, El-Naggar AK. Flow cytometric analysis of apoptosis and $\mathrm{Bcl}-2$ in primary breast carcinomas: clinical and biological implications. Cytometry 1996; 24: 116-122

39 McDonnel T), Deane N, Platt FM, Nunez G, Jaeger U, McKearn JP, Kors-meyer SJ. $\mathrm{Bcl}-2$ immunoglobulin transgenic mice demonstrate extended $\mathrm{B}$ cell survival and follicular lymphoproliferation. Cell 1989; $57: 79-88$

40 Hockenberry D, Nunez G, Milliman C, Schreiber RD, Korsmeyer SJ. Bcl-2 is an inner mitochondrial membrane protein that blocks programmed cell deaths. Nature 1990; 348: 334-336

41 Rydlander L, Ziegler E, Bergman T, Schoberl E, Steiner G, Bergman AC, Zetterberg A, Marberger M, Bjorklund P, Skern T, Einarsson R, Jornvall H. Molecular characterization of a tissue-polypeptide-specific-antigen epitope and its relation to human cytokeratin 18. Eur J Biochem 1996; 241: 309-314

42 Leers MPG, Kolgen W, Bjorklund V, Bergman T, Tribbick G, Persson B, Bjorklund P, Ramaekers FCS, Bjorklund B, Nap M, Jornvall H, Schutte B. Immunocytochemical detection and mapping of a cytokeratin 18 neo-epitope exposed during apoptosis. J Pathol 1999; 187: 567-572 


\section{CHAPTER 2}

\section{Androgen, estrogen and progesterone receptor expression in the human uterus during the menstrual cycle}

H.J.M.M. Mertens, M.J. Heineman, P.H.M.H. Theunissen, F.H. de Jong, J.L.H. Evers European Journal of Obstetrics and Gynecology and Reproductive Biology 2001; 98: 58-65 


\section{Abstract}

Cyclic changes in steroid receptor expression in endometrial cells are considered a reflection of its differential functions. Besides estrogens and progestogens, androgens have also been suggested to affect the biological function of the female reproductive tract. We investigated the distribution and intensity of immunocytochemical estrogen receptor (ER), progesterone receptor (PR) and androgen receptor (AR) staining in the various cell types of human endometrium and myometrium during the different menstrual cycle phases in 30 paraffin-embedded sections.

AR expression in endometrial stromal cells decreased gradually from early proliferative till mid secretory phase. In the late secretory phase, AR expression in all cell types distinguished. Staining of epithelial cells was moderate.

The disappearance of AR expression before cyclic separation of endometrial tissue may be causally related or just an epiphenomenon. Due to local competition for $5 \alpha$ reduction of testosterone and the excess of progesterone in the secretory phase, the level of dihydrotestosterone (DHT) will be diminished. Hypothetically, if AR synthesis in endometrium would be DHT dependent, it would explain the lack of AR expression in the late secretory phase. 


\section{Introduction}

The uterus is actively involved in providing the site of implantation. Expression of steroid receptors in endometrial glandular and stromal cells is considered a reflection of the differential functions with different requirements of hormone effects (1). The effects of estrogen and progestogens on proliferation and differentiation of endometrial cells and their cyclic changes within the menstrual cycle have been studied extensively, but the significance of androgens has only recently been suggested (1-6).

Immuno-cytochemistry with the use of specific monoclonal antibodies allows the visualisation of estrogen (ER), progesterone (PR) and recently also androgen receptors (AR) in individual cell types of the human uterus. The purpose of this study was to re-examine the expression of estrogen and progesterone receptors and to examine the expression of androgen receptors in the different cell types of the human endometrium and in myometrium.

\section{Material and methods}

Thirty patients between 29 and 46 years of age who were scheduled for hysterectomy for benign gynaecological abnormalities were included in the study. They complained of menorrhagia $(n=18)$, dysmenorrhoea $(n=8)$ or uterine prolaps $(n=4)$. All women had a regular menstrual cycle; none of them had a history of exogeneous hormonal therapy or recent disruption of the endometrial continuity (curettage, intra-uterine device) for at least two months preceding surgery.

Immediately after surgery, the removed uteri were opened and full-thickness samples, including endometrium and underlying myometrium, were obtained of the midfundus. These specimens were fixed in buffered formaldehyde $(3,7 \%)$ and routinely processed for paraffin embedding.

None of the uteri revealed histopathologic abnormalities. The endometrial dating criteria, described by Noyes and coworkers (7) were used to assess the phase of the menstrual cycle in haematoxylin-eosin stained sections of the midfundus region.

The histologic appearance of the endometrium was classified as $M$ : menstruation (days 1-5), EP: early proliferative (days 6-9), LP: late proliferative (days 10-14), ES: early secretory (days 15-18), MS: mid secretory (days 19-22) and LS: late secretory (days 23-28) phase. For each of these phases specimens from five representative uteri were collected. Only specimens with a histologic appearance that agreed with the date of the last menstrual period were included.

The Medical Ethical Committee of the hospital approved the study. At the time of the sample collection no patient consent was required for studies of archival tissue in the Netherlands.

\section{Immunostaining}

Steroid receptor immunocytochemistry was performed on paraffin-embedded sections. These sections were de-waxed, rehydrated and immersed for 10 minutes in methanol with $0,3 \% \mathrm{H}_{2} \mathrm{O}_{2}$ to block endogenous peroxidase activity. The sections were immersed in $0.01 \mathrm{M}$ sodium citrate buffer $(\mathrm{pH} 6.0)$ in a microwave-resistant container, 
and were then microwaved twice for 5 minutes at 700 Watts. After cooling to room temperature the sections were rinsed in phosphate-buffered saline (PBS)(pH 7.6). All sections were then pre-incubated with $1 \%$ bovine serum albumin in PBS for 15 minutes. The hormone receptors were detected using anti-ER (1D5, Dako ASS, Glostrup, Denmark), anti-PR (mPRI, Transbio, Paris, France) and anti-AR (F39.4, Biogenex, San Ramon, USA) at a dilution of 1:150, 1:1000 and 1:100 respectively. The sections were incubated with the antibodies overnight at room temperature.

After rinsing in PBS, sections were incubated with goat-anti-mouse-biotin (Oncogene Science, Uniondale NY, USA) for 1 hour at room temperature at a dilution of 1:400. After rinsing with PBS, the sections were incubated with strepABC (vector-elite-kit, Dako AS, Glostrup, Denmark) for 1 hour at room temperature at a dilution of 1:1:100 (ER:PR:AR).

As a negative control for background staining, the cells were stained using a mouse monoclonal antibody against BrdU (clone IIB5)(8). As positive controls for ER and PR Immunostaining, we used ER and PR positive breast tumour specimens; for AR immunostaining we used human benign prostate tissue ( $($ ).

$E R, P R$ and $A R$ immunocytochemistry on paraffin sections has been validated in previous studies $(9,10)$.

\section{Methodology}

Distribution and intensity of estrogen, progesterone and androgen receptor staining were scored semiquantitatively in cavitary epithelial cells (A), functional laminal glandular epithelial cells (B) and basal laminal glandular epithelial cells (C), functional laminal stromal cells (D) and basal laminal stromal cells (E) and in myometrial cells(F). Classification of staining intensity was assessed on separate cohorts of 100 cells in three different high power fields ( $x 400$ ), thus allowing assessment of heterogeneity in cell receptor content for a total number of 300 cells. Assessment of staining intensity profiles was random and blind: the menstrual cycle phase was unknown. After staining and steroid receptor scoring the menstrual cycle phase was identified. The intensity of specific staining was evaluated visually using a semiquantitative analysis as described by McCarty and coworkers (11), as follows:

receptor score $=\quad \sum_{\substack{i=0 \\ P}}^{\substack{i=4\\} \mathrm{i}}$

where $i$ is intensity of staining from o (no staining) to 4 (very intense staining) and $P(i)$ is percentage of cells stained with intensity $i$. The final receptor score was obtained by calculating the sum of the specific staining of the three cohorts. Intraobserver agreement was high $(r=0.96, P(0.00001)$ and interobserver agreement for the ER and PR scoring methods were also high ( $r=0.84$, Pro.0001 and $r=0.93, P r 0.00001$ respectively) (12). In this study, we evaluated the intra-observer differences of classification of staining intensity of the sections immunostained for AR by rescoring 21 of the sections. 


\section{Statistical analysis}

Histological appearance combined with recorded last menstrual period, were stratified at all menstrual cycle phases and cell types A-F. These data were analysed to examine the relationships between menstrual cycle phase or uterine region and receptor scores, by using one way analysis of variance. For analysis of intra-observer differences, the Spearmans' correlation coefficient was calculated. A P-value of less than 0.05 was considered significant.

\section{Results}

Staining for ER, PR as well as for AR was found to be limited to nuclei in myometrial and endometrial cells. Receptor staining was not observed in connective tissue or vascular wall elements. Immunostaining was not observed in negative controls (receptor score (RS) o) and could be confirmed in positive controls (RS $30 \pm 0$ ).

\section{ER Immunostaining (Table 1, Figure 1)}

Basal laminal stromal cells (average of all phases \pm std.dev. $=120 \pm 42$ ), functional laminal stromal cells $(107 \pm 41)$ and myometrial cells $(69 \pm 41)$ showed less intensive staining of ER than epithelial cells. Receptor scores of glandular epithelial cells decreased from basal laminal endometrium (169 \pm 70$)$ via functional laminal endometrium ( $155 \pm 58$ ) to scores of cavitary epithelial cells (121 \pm 61 ).

Expression of ER reached a maximum in the early proliferative phase in all cell types of the uterus, with a minor (non-significant) decrease in the late proliferative and in the secretory phases.

In the early secretory phase ER staining declined sharply in stromal and myometrial cells, whereas in epithelial cells ER staining persisted into the mid secretory phase. During the mid and late secretory phases, the ER content of smooth muscle cells and of predecidualizing stromal cells around spiral arterioles increased slightly.

Statistical significant differences between steroid receptor expression in the different menstrual cycle phases as well as in the different layers of the endometrium or myometrium, are shown by superscripts in table 1 .

\section{PR Immunostaining (Table 1, Figure 1)}

PR expression of basal laminal glandular epithelial cells (average of all phases \pm std.dev. $=184 \pm 32$ ) and functional laminal glandular epithelial cells (131 \pm 103$)$ was strong and reached a maximum in the late proliferative and early secretory phases, with a significant drop in the mid and late secretory phases. Nuclear PR staining in cavitary epithelial cells increased significantly from menstruation to the late proliferative and early secretory phase of the cycle; in the mid and late secretory phases PR decreased significantly. PR staining of basal laminal and functional laminal stromal cells increased gradually until the early and late proliferative phase, and diminished in the luteal phase of the menstrual cycle.

Myometrial cells showed consistently strong nuclear PR immunostaining throughout the menstrual cycle (average of all phases \pm std.dev. $=194 \pm 12$ ). 
Table 1 Steroid hormone receptor content

Estrogen, progesterone and androgen receptor scores $( \pm$ the standard deviations) for endometrial epithelial, glandular and stromal cells and for myometrial cells in the various phases of the menstrual cycle.

Corresponding superscripts mean non-significant differences; different superscripts mean significant differences.

\begin{tabular}{|c|c|c|c|c|c|c|}
\hline ER & M & EP & LP & ES & MS & LS \\
\hline Cell type A & $0^{*}$ & $216 \pm 30^{\circ}$ & $141 \pm 43^{\text {th }}$ & $143 \pm 30^{\text {th }}$ & $54 \pm 13^{d}$ & $53 \pm 35^{4}$ \\
\hline Cell type B & $189 \pm 41^{\epsilon}$ & $244 \pm 19^{\mathrm{s}}$ & $19 \pm 21^{\mathrm{H}}$ & $237 \pm 9^{b t}$ & $93 \pm 31^{\text {th }}$ & $78 \pm 61^{\text {chth }}$ \\
\hline Cell type C & $234 \pm 25^{M}$ & $222 \pm 10^{b t}$ & $190 \pm 36^{\epsilon}$ & $223 \pm 4^{\mathrm{m}}$ & $88 \pm 29^{4}$ & $59 \pm 37^{\circ}$ \\
\hline Cell type D & $153 \pm 27^{\text {th }}$ & $160 \pm 5^{c}$ & $123 \pm 9^{b}$ & $76 \pm 20^{4}$ & $66 \pm 6^{4}$ & $63 \pm 19^{4}$ \\
\hline Cell type E & $140 \pm 28^{5}$ & $174 \pm 11^{c}$ & $164 \pm 92^{b k}$ & $57 \pm 22^{4}$ & $96 \pm 31^{\text {d d }}$ & $92 \pm 30^{\text {cd }}$ \\
\hline Cell type F & $91 \pm 46^{\text {cth }}$ & $132 \pm 38^{\text {कh }}$ & $92 \pm 27^{\text {th }}$ & $22 \pm 5^{n}$ & $60 \pm 4^{x}$ & $18 \pm 21^{8}$ \\
\hline
\end{tabular}

\begin{tabular}{|c|c|c|c|c|c|c|}
\hline PR & M & EP & LP & ES & MS & LS \\
\hline Cell type A & $41 \pm 38^{*}$ & $109 \pm 24^{b}$ & $198 \pm 4^{c}$ & $225 \pm 46^{\text {catm }}$ & $21 \pm 15^{* 8}$ & $23 \pm 16^{\text {wh }}$ \\
\hline Cell type B & $88 \pm 51^{\text {ab }}$ & $178 \pm 31^{e}$ & $253 \pm 4^{*}$ & $250 \pm 4^{d m}$ & $15 \pm 5^{2}$ & $\sigma^{b}$ \\
\hline Cell type C & $191 \pm 40^{\circ}$ & $240 \pm 8^{d}$ & $279 \pm 5^{t}$ & $243 \pm 37^{\text {tam }}$ & $125 \pm 42^{50}$ & $30 \pm 13^{\text {as }}$ \\
\hline Cell type D & $97 \pm 6^{b}$ & $107 \pm 44^{b}$ & $146 \pm 11^{\circ}$ & $136 \pm 1^{\circ}$ & $78 \pm 15^{b}$ & $47 \pm 5^{48}$ \\
\hline Cell type E & $108 \pm 24^{b}$ & $171 \pm 38^{\circ}$ & $102 \pm 2^{b}$ & $91 \pm 3^{b}$ & $108 \pm 20^{b}$ & $67 \pm 25^{\text {th }}$ \\
\hline Cell type F & $199 \pm 22^{c}$ & $193 \pm 37^{c}$ & $193 \pm 35^{\circ}$ & $188 \pm 40^{\circ}$ & $175 \pm 27^{e}$ & $214 \pm 9^{\mathrm{m}}$ \\
\hline
\end{tabular}

\begin{tabular}{|c|c|c|c|c|c|c|}
\hline AR & M & EP & LP & ES & MS & LS \\
\hline Cell type A & $0^{\circ}$ & $5 \pm 8^{\circ}$ & $14 \pm 10^{\circ}$ & $2 \pm 3^{a}$ & $19 \pm 15^{\text {क }}$ & $0^{\circ}$ \\
\hline Cell type B & $\sigma^{\circ}$ & $2 \pm 3^{*}$ & $\sigma^{\circ}$ & $\sigma^{*}$ & $5 \pm 11^{*}$ & $0^{\circ}$ \\
\hline Cell type C & $0^{\circ}$ & $0^{\circ}$ & $0^{\circ}$ & $0^{\circ}$ & $0^{\circ}$ & $0^{\circ}$ \\
\hline Cell type D & $17 \pm 2^{b}$ & $71 \pm 24^{d}$ & $62 \pm 22^{\text {ed }}$ & $37 \pm 32^{4}$ & $41 \pm 22^{4}$ & $0^{\circ}$ \\
\hline Cell type E & $30 \pm 23^{4}$ & $102 \pm 28^{\circ}$ & $79 \pm 9^{d}$ & $38 \pm 27^{4}$ & $26 \pm 12^{4}$ & $\sigma^{\circ}$ \\
\hline Cell type F & $70 \pm 5^{t}$ & $66 \pm 9^{d}$ & $56 \pm 16^{d}$ & $49 \pm 20^{16 t}$ & $33 \pm 7^{4}$ & $\sigma^{\circ}$ \\
\hline
\end{tabular}

\section{AR Immunostaining (Table 1, Figure 1,2)}

Evaluation of intra-observer correlation by repeated analysis of AR immunostaining intensity showed significant agreement in receptor scores in glandular $(r=0.89$. Pro.00001), stromal ( $r=0.96$, Pro.00001) and smooth muscle $(r=0.93$, Pro.0001) cells. 
In comparison with ER and PR receptor scores, immunostaining of AR was less intens. Epithelial cells showed hardly any AR expression throughout the menstrual cycle.

In stromal cells, AR receptor scores reached a maximum in the early proliferative phase with a gradual decrease during the remaining cycle phases. This decrease was more obvious in basal laminal stromal cells than in functional laminal stromal cells. In myometrial cells, there was no significant difference in immunostaining in the menstruation, proliferative, early and mid secretory phases $(p=0.938)$. Myometrial cells in the late secretory phase did not stain for AR.

AR immunostaining of stromal and smooth muscle cells was more profound than AR staining of glandular cells, except for the late secretory phase, when no immunostaining was found in any of the cell types.

Figure 1 Steroid Receptor expression in different menstrual cycle phases
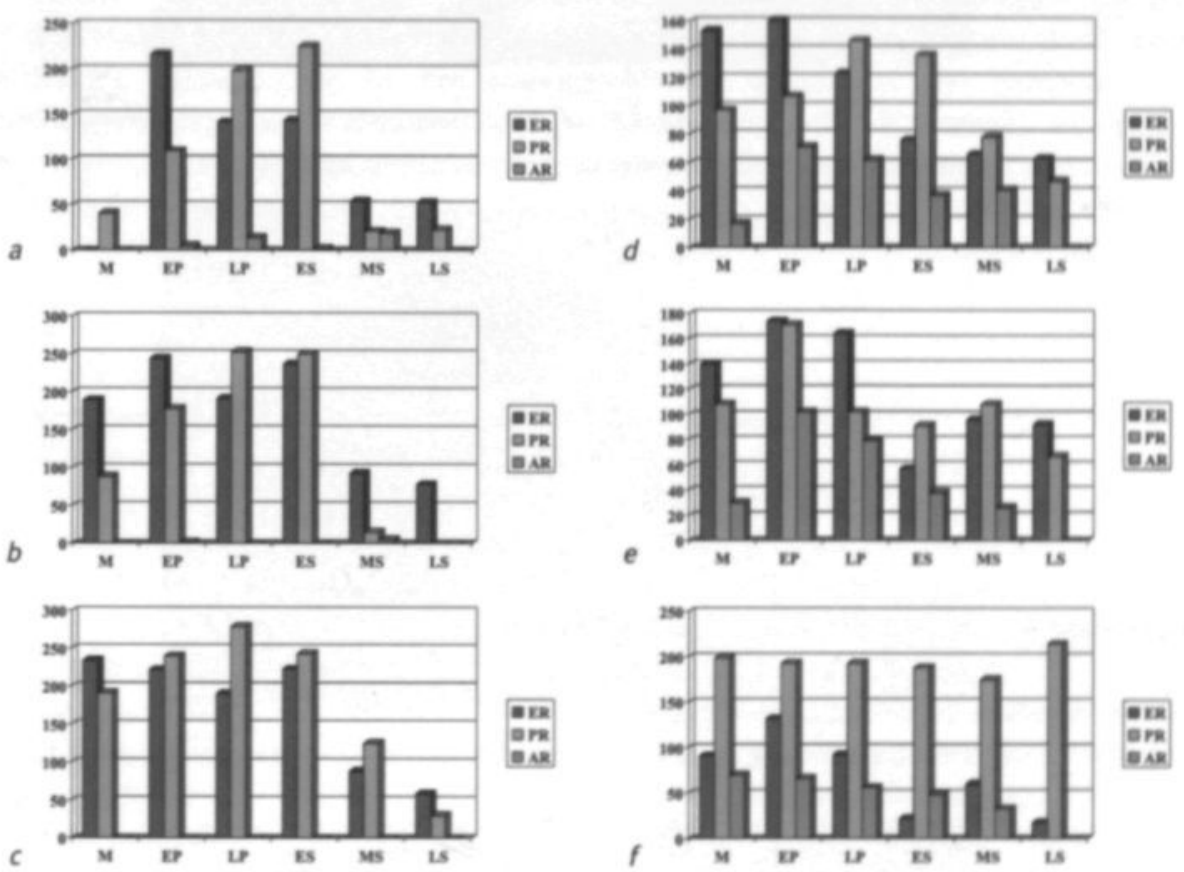

\section{Legend Figure 1 and Table 1}

$$
\begin{aligned}
& E R=\text { estrogen receptor } \\
& P R=\text { progesterone receptor } \\
& A R=\text { androgen receptor }
\end{aligned}
$$
A = cavitary epithelial cells
B = functional laminal glandular epithelial cells
$C=$ basal laminal glandular epithelial cells
D = functional laminal stromal cells
$\mathbf{E}=$ basal laminal stromal cells
$\mathbf{F}=$ myometrial cells
$M=$ menstruation phase
$E P=$ early proliferative phase
LP = late proliferative phase
ES = early secretory phase
MS = mid secretory phase
LS = late secretory phase


Figure 2A Staining for Androgen Receptor (AR) expression, shown by brown cells in the early secretory phase. Stromal cells show positive staining; all glandular cells show no staining for $A R$.

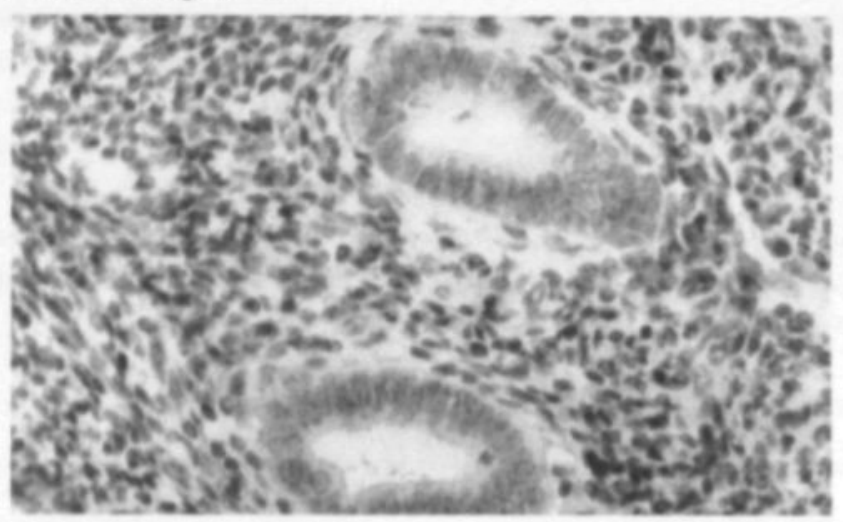

Figure $2 B$ Staining for $A R$ expression, shown by brown cells in the late secretory phase. Stromal cells as well as epithelial cells show no staining for AR.

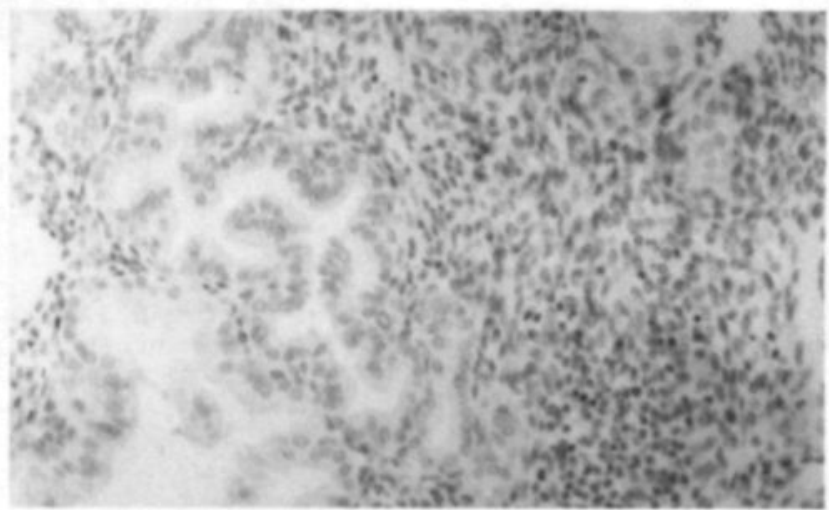

Figure $2 C$ Anti-BrdU $m A b$ as a negative control for $A R$ immunostaining. No staining is shown.

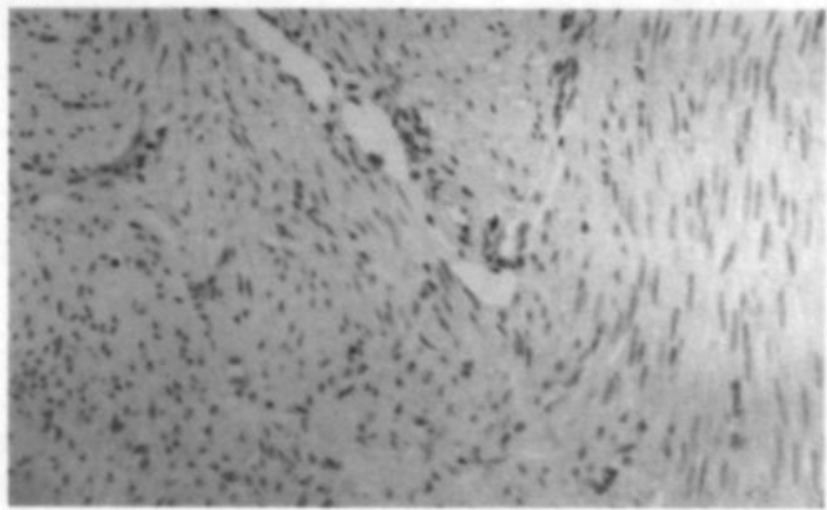




\section{Discussion}

The present study describes the steroid receptor content of the various cell types of human endometrium and myometrium by immunostaining of ER, PR and AR after micro-wave antigen retrieval pre-treatment of routinely fixed, paraffin-embedded tissue. Human endometrium and myometrium showed strong ER and PR expression in all uterine cell types during the proliferative phases of the menstrual cycle. In the secretory phases, ER and PR content decreased significantly. These results confirm the results of previous studies (2,12-15).

The knowledge of the AR content in the respective layers of the human endometrium and in the myometrium is incomplete. Investigating the presence of AR in human endometrium, Muechler and coworkers (3), Punnonen and coworkers (14) as well as Tamaya and coworkers (15) studied androgen binding to soluble proteins from the cytosol. Hirai and coworkers (4) studied the distribution of androgen receptor messenger RNA in rats by Northern blot analysis and in situ hybridisation using probes corresponding to the androgen-binding domain of the receptor. Also autoradiographic methods have been used for localising the AR (5,16-17).

Recently localisation AR in female reproductive tissues by immunohistochemistry has been introduced $(6,9,18)$. By this method, androgen receptor expression in different normal human cell types during the phases of the menstrual cycle can be described in detail.

In this study endometrial epithelial cells showed no AR expression during the menstrual cycle. Basal laminal stromal cells (figure $1 A, 1 B$ ) showed highest $A R$ expression in the early proliferative phase with a gradually decrease during the late proliferative and early and mid secretory phases. In the mid secretory phase AR staining was very low, in the late secretory phase AR staining was not detected. AR immunostaining of functional laminal stromal cells showed the same cyclic pattern, but was less intense than the staining in basal laminal stromal cells. Myometrial cells showed a gradual decrease of AR expression in the secretory phases. AR expression also disappeared in the late secretory phase.

Androgens have been shown to increase AR expression, possibly by a mechanism of autoregulation. In rat prostatic tissue, Prins and coworkers (19) showed immunodetectable AR to decline within 2-7 days after castration-induced androgen withdrawal. AR immunostaining returned within 1-3 days after testosterone replacement. A similar mechanism may be responsible for the pattern of AR expression during the cycle, if the uterine levels of dihydrotestosterone (DHT), the active metabolite of testosterone, may fluctuate. Such a conversion of testosterone to DHT is a prerequisite for androgen action in other genital tissues as well, e.g. during the development of the male external genitalia, urethra and prostate (21).

Presently, there is no evidence of large fluctuations of peripheral levels of testosterone or DHT during the menstrual cycle. However, postovulatory excess of progestogens may force these steroids as easily available substrates for $s \boldsymbol{\alpha}$-reduction, resulting in high levels of $5 \alpha$-reduced progesterone in the secretory phase (21). Due to local competition for $s \alpha$-reduction between testosterone (pmol serum concentrations) and progesterone (nmol serum concentrations) during the second half of the menstrual cycle, the reduction of progesterone may increase and reduction of testosterone may decrease in the late secretory phase of the cycle. 
If AR synthesis in human endometrial cells, in analogy with that in prostate cells, would be DHT dependent, the diminished level of DHT, in favour of the increased level of $5 \alpha$-reduced progesterone, would explain the lack of AR immunostaining in the late secretory phase of the menstrual cycle. The precipitous disappearance of progesterone from the circulation in the days preceding menses, and the resulting loss of competitive inhibition of testosterone conversion to DHT, would then explain the subsequent rapid return of AR in the early proliferative phase.

In the present study ER, PR and AR expression have been visualised during the menstrual cycle. All three steroid receptors play definitively a role in function and morphology changes of human endometrial and myometrial cells throughout the menstrual cycle. The mode of androgen action and their modulative, or causal, role in the separation of endometrial tissue from its basal layer during the menstrual period has to be further investigated.

\section{Acknowledgements}

Brinkmann AO, Debets-Te Baerts MJ, Koudstaal Joh, Leers MPG, Snijders MPML

\section{References}

1 Noe M, Kunz G, Herbertz M, Mall G, Leyendecker G. The cyclic pattern of immunocytochemical expression of oestrogen and progesterone receptors in human endometrium myometrial and endometrial layers: Characterisation of the endometrial-subendometrial unit. Hum Reprod 1999; 14: 190-197

2 Narukawa S, Kanzaki H, Inoue T, Imai K, Higuchi T, Hatayama H, Kariya M, Mori T. Androgens induce prolactin production by human endometrial stromal cells in vitro. J Clin Endocrinol Metab 1994; 78: 165-168

3 Muechler EK. The androgen receptor of the human endometrium. Endocrine research 1987; 13(1): 69-84

4 Hirai M, Hirata S, Osada T, Hagihara K, Kato J. Androgen receptor mRNA in the rat ovary and uterus I Steroid Biochem Molec Biol 1994; 49: 1-7

5 Bonney RC, Scanlon MJ, Jones DL. Adrenal androgen concentrations in endometrium and plasma during the menstrual cycle. J Endocr 1994; 101: 181188

6 Horie K, Takakura K, Imai K, Liao S, Mori T. Immunohistochemical localization of androgen receptor in the human endometrium, decidua, placenta and pathologic conditions of the endometrium. Human Reproduction 1992; 7: 1461. 1466

7 Noyes RW, Herig AT, Rock J. Dating the endometrial biopsy. Fertil Steril 1950; (1): 3-10

8 Schutte B, Reynders MMJ, Bosman FT, Blijham GH. Studies with antibromodeoxyuridine antibodies II: Simultaneous detection of antigen detection and DNA synthesis by in vivo labeling of mouse intestinal mucosa. ). Histochem. Cytochem 1987; 35: 371-374

9 Janssen PJ, Brinkmann AO, Boersma WJ, van de Kwast TH. Immunohistochemical detection of androgen receptor with monoclonal antibody $\mathrm{F}_{39.4}$ in routinely processed, paraffin-embedded human tissues after microwave pre-treatment. J. 
Histochem. Cytochem 1994: 42: 1169-1175

10 Snijders MPML, Theunissen PHMH, Debets-Te Baerts MJ, Koudstaal Joh. Immunohistochemischer Nachweiss von Oestrogen- und Progesteronreceptoren in Paraffinschnitten. Pathologe 1990; 11: 236-239

11 McCarty KS Jr, Milller LS, Cox EB, Konradt J, McCarty KS Sr. Estrogen receptor analyses: correlation of biochemical and immunochemical methods using monoclonal antireceptor antibodies. Arch Pathol Lab Med 1985; 109: 716-721

12 Snijders MPML, de Goeij AF, Debets-Te Baerts MJ, Rousch MJ, Koudstaal Joh, Bosman FT. Immunocytochemical analysis of oestrogen and progesterone receptors in the normal human uterus throughout the menstrual cycle and after menopause. J Reprod Fert 1992; 94: 361.369

13 Ben-Hur H, Mor G, Insler V, Blickstein I, Amir-Zaltsman Y, Kohen F. Assessment of estrogen receptor distribution in human endometrium by direct immunofluorence. Acta Obstet Gynecol Scand 1995: 74: 97-102

14 Punnonen R, Pettersson K, Vanharanta R. Androgen, estrogen and progestin cytosol receptor concentrations in the normal human endometrium. Effects of intrauterine device Gynecol Obstet Invest 1994; 17: 73-77

15 Tamaya T, Murakami T, Okada H. Concentrations of steroid receptors in normal human endometrium in relation to the day of the menstrual cycle. Acta Obstet Gynecol Scand 1986; 65: 195-198

16 Takeda H, Mizuno T, Lasnitzki I. Autoradiographic studies of androgen-binding sites in the rat urogenital sinus and postnatal prostate. J Endocr 1985; 104: 8792

17 Stumf WE, Sar M. Autoradiographic techniques for localizing steroid hormones. Meth Enzym 1975; 36: 135-156

18 Takeda H, Chodak G, Mutchnik S, Nakamoto T, Chang C. Immunohistochemical localisation of androgen receptors with mono- and polyclonal antibodies to androgen receptor. J Endocr 1990; 126: 17-25

19 Prins GS, Birch L. Immunocytochemical analysis of androgen receptor along the ducts of the separate rat prostate lobes after androgen withdrawal and replacement. Endocr 1993; 32: 169-178

20 Ruizeveld de Winter JA, Trapman J, Vermey M, Mulder E, Zegers ND, van de Kwast $\mathrm{TH}$. Androgen receptor expression in human tissues: an immunohistochemical study. J Histochem Cytochem 1991; 39: 927-936

21 Wilson JD, Griffin JE, Russell DW. Steroid $5 \alpha$-reductase 2 deficiency. Endocr Rev 1993; 14: 577-593 
CHAPTER 3

\section{The expression of apoptosis-related proteins Bcl-2 and Ki67 in endometrium of ovulatory menstrual cycles}

H.J.M.M. Mertens, M.J. Heineman, J.L.H. Evers

Gynecologic and Obstetric Investigation 2002; 53: 224-230 


\section{Abstract}

During the menstrual cycle, a rapid sequence of proliferation, differentiation and cell death occurs in the human endometrium. Mechanisms involved in cell proliferation have been studied extensively. Apoptosis has recently been recognised to be a physiologic phenomenon. The aim of this study was to investigate the mechanisms involved in hormone-dependent tissue remodelling by measuring $\mathrm{Bcl}-2$, an apoptosis inhibitor, and Ki67, a proliferation marker, as expressed in normal human endometrium.

Paraffin-embedded endometrial sections of thirty uteri were immunostained for $\mathrm{Bcl}-\mathbf{2}$ and Ki67; expression was scored in cavitary epithelium, functional and basal glandular epithelial and stromal cells of the endometrium.

$\mathrm{Bcl}-2$ expression increased in the proliferative phases and decreased significantly in the secretory phases, especially in glandular epithelial cells (131 \pm 45 for functional laminal cells and $227 \pm 68$ for basal laminal cells to o). Ki67 expression showed the same cyclic pattern with a later onset $(145 \pm 63$ for functional laminal cells and $13 \pm$ 8 for basal laminal cells to o).

$\mathrm{Bcl}-2$ promotes cell survival by preventing apoptosis. Proliferation is the result of increasing estradiol concentration, high estrogen receptor expression and growth hormones and high $\mathrm{BCl}-2$ and $\mathrm{Ki}_{7} 7$ expression. After the onset of progesterone production, $\mathrm{Bcl}-2$ levels decrease and $\mathrm{Ki} 67$ levels and androgen receptor expression in stromal cells disappear resulting in cell disintegration and menstruation. Persistent $\mathrm{Bcl}-2$ expression, like we saw in basal laminal stromal and epithelial cell accounts for the privilege of escaping from apoptosis-inducing signals. This allows reconstruction of the functional endometrium from its preserved basal layer after menstruation. 


\section{Introduction}

Human endometrium undergoes a rapid cycling process of proliferation, differentiation and cell death under the influence of estradiol and progesterone (1-4). For homeostatic tissue growth, a tight balance must be maintained between cell proliferation and cell loss. The mechanism involved in cell proliferation has been studied extensively, cell death has only later been recognized as an important phenomenon (5-11).

Cell death has long been considered as a pathologic process. It is now, however, recognized as a normal physiologic phenomenon in normal tissue renewal, metamorphosis, embryonic development and hormone-induced atrophy (2-3.5.9-12). This physiologic type of cell death, apoptosis, or programmed cell death, targets single cells and can as such be differentiated morphologically from necrosis, which is induced by pathologic stimuli $(5,7,8)$ and usually affects tissues.

Physiologic cell death relies on processes, built-in cellular mechanisms that can be modulated by extracellular stimuli, such as hormones. The protein $\mathrm{Bcl}-2$ has been shown to prolong cell survival by preventing apoptosis $(5,10,11,13)$. Ki67 is a protein which is expressed in cycling cells from the $G_{1}$ to the $M$ phases $(10,11)$. Because human endometrium undergoes rapid proliferation and differentiation it is an excellent model to study the cyclic modulation of $\mathrm{Bcl}-2$ and Ki67.

We compared the expression of $\mathrm{Bcl}-2$ with the proliferative fraction, using Ki67 expression, in the various endometrial components. The aim of this study was to investigate mechanisms involved in the survival of endometrial cells during the different phases of the ovulatory menstrual cycle by measuring $\mathrm{Bcl}-2$ and $\mathrm{Ki}_{7}$ expression.

\section{Material and Methods}

\section{Patients}

Thirty patients between 29 and 46 years of age who were scheduled for hysterectomy for benign gynecological conditions were included in the study. They complained of menorrhagia $(n=18)$, dysmenorrhea $(n=8)$ or uterine prolapse $(n=4)$. All women had a regular menstrual cycle; none of them had a history of exogenous hormonal therapy or recent disruption of the endometrial continuity (curettage, intrauterine device) for at least 2 months preceding surgery.

The Medical Ethical Committee of the hospital approved this study. At the time of sample collection no patient consent for studies on archival tissue was required in The Netherlands.

\section{Uterine Tissue Samples}

Immediately after surgery, the removed uteri were opened and full-thickness samples, including endometrium and underlying myometrium, were obtained of the midfundus. These specimens were fixed in buffered formaldehyde (3.7\%) and processed routinely for paraffin embedding.

None of the uteri revealed histopathologic abnormalities. The endometrial dating criteria described by Noyes and coworkers (14), were used to assess the phase of the menstrual cycle in hematoxylin-eosin-stained sections of the midfundus region. 
The histologic appearance of the endometrium was classified as $M=$ menstruation (days $1-5$ ), EP = early proliferative (days 6-9), LP = late proliferative (days 10-14), ES = early secretory (days 15-18), MS = mid-secretory (days 19-22) and $L S=$ late secretory (days 23-28) phase. For each of these phases specimens from 5 representative uteri were collected. The histologic appearance of the endometrium of all specimens agreed with the date of the last menstrual period.

\section{Immunostaining}

Paraffin-embedded sections were immunostained with the monoclonal antibodies Bcl2 (clone 124, 1:40, Dako AS, Glostrup, Denmark) and Ki67 (clone MIB-I, 1:90, Immunotech, Marseille, France) using a streptavidine-biotin-peroxidase complex method and a solution with 3.3-diaminobenzidine as a substrate in a $0.002 \% \mathrm{H}_{2} \mathrm{O}_{2}$ solution (Sigma Chemical Co., St. Louis, Mo., USA) to visualize the immune complexes. Before immunostaining paraffin sections with the primary antibodies, both the Ki67. $\mathrm{Ag}$ epitope and the $\mathrm{Bcl}-2$ epitope, were unmasked by heating the tissue sections in a $0.1 \mathrm{M}$ citrate buffer $(\mathrm{pH}=6.0)$ for $10 \mathrm{~min}$ in a microwave oven. After immunostaining, the sections were counterstained with Harris' hematoxylin, dehydrated, cleared in xylene and finally embedded in Entellan.

As a negative control for background staining by the primary antibody, the sections were incubated with a nonrelevant mouse immunoglobulin (Dako).

\section{Methodology}

In cavitary epithelium (A), glandular epithelial cells of functional (B) and basal (C) endometrium, stromal cells of functional (D) and basal (E) endometrium and in myometrial cells (F), staining was assessed on separate cohorts of 100 cells in three different high power fields ( $x$ 400), allowing assessment of heterogeneity in cell receptor content for a total number of 300 cells. Assessment of staining was random and single-blinded: the investigator was kept unaware of the phase of the menstrual cycle in which the tissue specimen was obtained.

\section{Statistical Analysis}

Histological appearance as related to the first day of the most recent menstrual period was stratified at all menstrual cycle phases and cell types A-F. These data were analyzed to examine the relationships between menstrual cycle phase or uterine region and $\mathrm{Bcl}-2$ - and $\mathrm{Ki67}$-positive staining scores. The Mann-Whitney $U$ test was used to estimate significant differences: a p value of less than 0.05 was considered to reflect statistically significant differences.

\section{Results}

Immunostaining of $\mathrm{Bcl}-2$ was distributed evenly within the cytoplasm and was occasionally granular and perinuclear. Vessels and interstitial cells in the myometrium stained for $\mathrm{Bcl}-2$ and $\mathrm{Ki} 67$; we did not analyze cyclic variations of staining in these cell types. 


\section{Bcl-2}

Cyclic variations in Bcl-2 expression were predominantly seen in glandular epithelial cells (table 1, fig. 1); $\mathrm{Bcl}-2$ expression increased from menstruation till the late proliferative phase, with a higher intensity in basal endometrium. In glandular cells of functional endometrium $\mathrm{Bcl}-2$ expression decreased in the secretory phases; in glandular epithelial cells of basal endometrium it disappeared at the onset of secretory activity. This decrease was statistically significant. When secretory characteristics were present the staining was granular, distributed in clumps and confined to certain areas of the cytoplasm.

In cavitary epithelial cells, staining for Bcl-2 was less than in glandular epithelial cells and only showed a slight, nonsignificant increase during the menstrual cycle. Immunostaining of $\mathrm{Bcl}-2$ in stromal cells was rarely seen in functional endometrium but was strong in basal endometrium throughout the menstrual cycle. In the mid and late secretory phase, as well as in the menstruation phase, Bcl-2 expression was significantly higher in basal than in functional endometrial stromal cells. Myometrial cells were strongly stained, irrespective of the phase of the menstrual cycle (fig. 2).

Table $1 \quad B C l-2$ expression in all phases of the menstrual cycle

Positive staining scores ( \pm standard deviations) of $\mathrm{BCl} \cdot 2$ for endometrial epithelial, glandular and stromal cells and for myometrial cells in the various phases of the menstrual cycle.

Identical superscripts indicate non-significant differences in rows and columns; different superscripts indicate significant differences.

\begin{tabular}{|l|c|c|c|c|c|c|}
\hline Bcl-2 & M & EP & LP & ES & MS & LS \\
\hline Cavitary epithelium & $0^{\mathrm{a}}$ & $20 \pm 20^{\mathrm{a}}$ & $63 \pm 79^{\mathrm{ab}}$ & $29 \pm 35^{\mathrm{ab}}$ & $31 \pm 38^{\mathrm{a}}$ & $131 \pm 84^{\mathrm{ab}}$ \\
\hline $\begin{array}{l}\text { Glandular epithelium } \\
\text { of functional layer }\end{array}$ & $61 \pm 28^{\mathrm{ab}}$ & $77 \pm 64^{\mathrm{ab}}$ & $131 \pm 45^{\mathrm{b}}$ & $59 \pm 54^{\mathrm{ab}}$ & $0^{\mathrm{a}}$ & $35 \pm 31^{\mathrm{ab}}$ \\
\hline $\begin{array}{l}\text { Glandular epithelium } \\
\text { of basal layer }\end{array}$ & $123 \pm 54^{\mathrm{b}}$ & $173 \pm 56^{\mathrm{b}}$ & $227 \pm 68^{\mathrm{b}}$ & $0^{\mathrm{a}}$ & $0^{\mathrm{a}}$ & $29 \pm 57^{\mathrm{a}}$ \\
\hline $\begin{array}{l}\text { Stroma } \\
\text { of functional layer }\end{array}$ & $0^{\mathrm{a}}$ & $0^{\mathrm{a}}$ & $53 \pm 66^{\mathrm{ab}}$ & $0^{\mathrm{a}}$ & $3 \pm 6^{\mathrm{a}}$ & $0^{\mathrm{a}}$ \\
\hline $\begin{array}{l}\text { Stroma } \\
\text { of basal layer }\end{array}$ & $192 \pm 39^{\mathrm{b}}$ & $105 \pm 62^{\mathrm{ab}}$ & $102 \pm 72^{\mathrm{ab}}$ & $75 \pm 21^{\mathrm{ab}}$ & $192 \pm 45^{\mathrm{b}}$ & $184 \pm 75^{\mathrm{b}}$ \\
\hline $\begin{array}{l}\text { Myometrium } \\
\text { Myom }\end{array}$ & $116 \pm 39^{\mathrm{b}}$ & $162 \pm 51^{\mathrm{b}}$ & $164 \pm 85^{\mathrm{b}}$ & $90 \pm 61^{\mathrm{ab}}$ & $112 \pm 41^{\mathrm{b}}$ & $144 \pm 69^{\mathrm{b}}$ \\
\hline
\end{tabular}

\section{Legend Table 1,2 and Figure 1}
A = cavitary epithelial cells
B = functional laminal glandular epithelial cells
C = basal laminal glandular epithelial cells
$D=$ functional laminal stromal cells
$\mathrm{E}=$ basal laminal stromal cells
$\mathrm{F}=$ myometrial cells

$M=$ menstruation phase

$E P=$ early proliferative phase

$\mathrm{LP}=$ late proliferative phase

$E S=$ early secretory phase

$M S=$ midsecretory phase

$\mathrm{LS}=$ late secretory phase 
Figure 1 Immunostaining for $\mathrm{BCl}-2$ in functional and basal endometrium and in myometrium

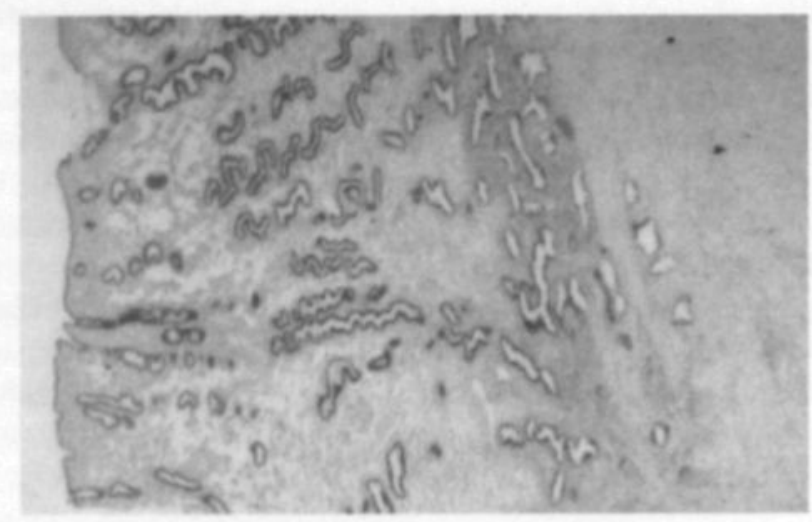

\section{Ki67}

Ki67 expression was more intense, but not significantly different, in epithelial cells than in stromal cells (fig. 3). In cavitary epithelial and glandular epithelial cells of functional and basal endometrium Ki67 immunostaining was positive in the proliferative phases. In the late secretory phase Ki67 immunostaining was absent. In stromal cells of functional endometrium Ki67 immunostaining was seen throughout the menstrual cycle phases; there were no statistically significant differences. In stromal cells of basal endometrium and in myometrial cells Ki67 expression was seen only in the menstruation phases and for the latter also hardly seen in the mid and late secretory phase.

Table $2 \quad K i 67$ expression in all phases of the menstrual cycle

Positive staining scores ( \pm standard deviations) of Ki67 for endometrial epithelial, glandular and stromal cells and for myometrial cells in the various phases of the menstrual cycle.

Identical superscripts indicate non-significant differences in rows and columns; different superscripts indicate significant differences.

\begin{tabular}{|l|c|c|c|c|c|c|}
\hline KI67 & M & EP & LP & ES & MS & LS \\
\hline Cavitary epithelium & $0^{\mathrm{a}}$ & $69 \pm 51^{\mathrm{ab}}$ & $23 \pm 32^{\mathrm{a}}$ & $5 \pm 5^{\mathrm{a}}$ & $4 \pm 8^{\mathrm{a}}$ & $0^{\mathrm{a}}$ \\
\hline $\begin{array}{l}\text { Glandular epithelium } \\
\text { of functional layer }\end{array}$ & $31 \pm 62^{\mathrm{a}}$ & $145 \pm 63^{\mathrm{b}}$ & $62 \pm 39^{\mathrm{ab}}$ & $95 \pm 52^{\mathrm{ab}}$ & $0^{\mathrm{a}}$ & $0^{\mathrm{a}}$ \\
\hline $\begin{array}{l}\text { Glandular epithelium } \\
\text { of basal layer }\end{array}$ & $0^{\mathrm{a}}$ & $5 \pm 7^{\mathrm{a}}$ & $13 \pm 8^{\mathrm{a}}$ & $8 \pm 11^{\mathrm{a}}$ & $2 \pm 4^{\mathrm{a}}$ & $0^{\mathrm{a}}$ \\
\hline $\begin{array}{l}\text { Stroma } \\
\text { of functional layer }\end{array}$ & $5 \pm 4^{\mathrm{a}}$ & $10 \pm 16^{\mathrm{a}}$ & $11 \pm 6^{\mathrm{a}}$ & $9 \pm 15^{\mathrm{a}}$ & $12 \pm 7^{\mathrm{a}}$ & $22 \pm 11^{\mathrm{a}}$ \\
\hline $\begin{array}{l}\text { Stroma } \\
\text { of basal layer }\end{array}$ & $1 \pm 2^{\mathrm{a}}$ & $0^{\mathrm{a}}$ & $0^{\mathrm{a}}$ & $0^{\mathrm{a}}$ & $1 \pm 2^{\mathrm{a}}$ & $3 \pm 4^{\mathrm{a}}$ \\
\hline & $199 \pm 22^{\mathrm{b}}$ & $0^{\mathrm{a}}$ & $0^{\mathrm{a}}$ & $0^{\mathrm{a}}$ & $0^{\mathrm{a}}$ & $0^{\mathrm{a}}$ \\
\hline
\end{tabular}


Figure 2 Immunostaining for Ki67 in functional and basal endometrium and in myometrium

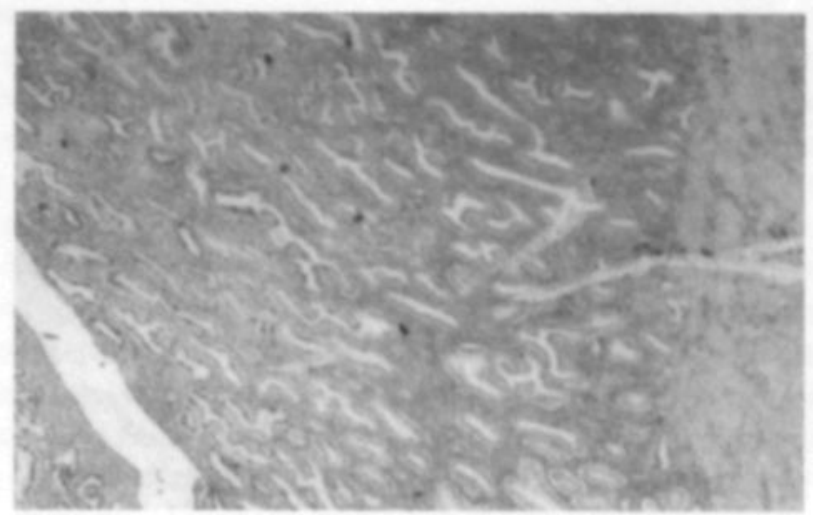

Figure $3 \mathrm{BCl}-2$ and $\mathrm{Ki} / 67$ in the menstrual cycle phases

a
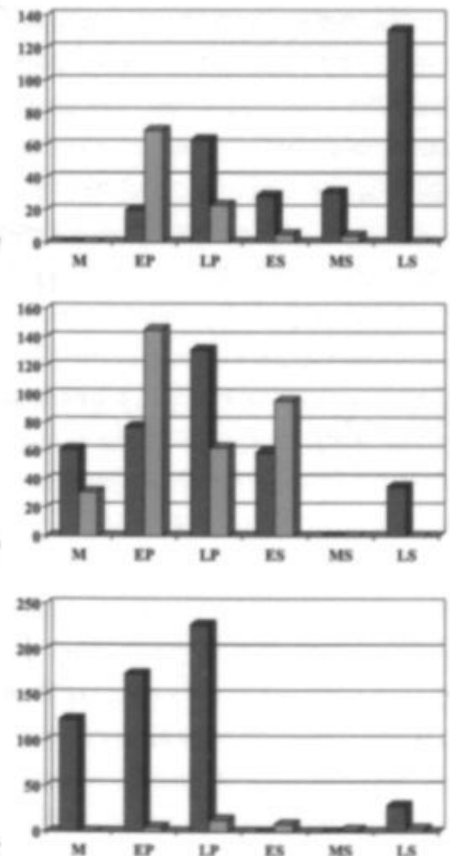

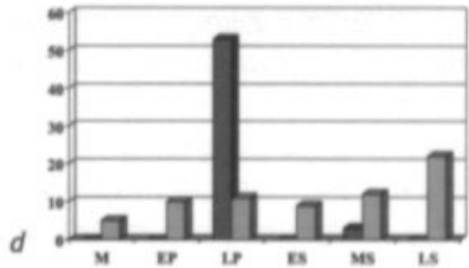

anat Ekis?
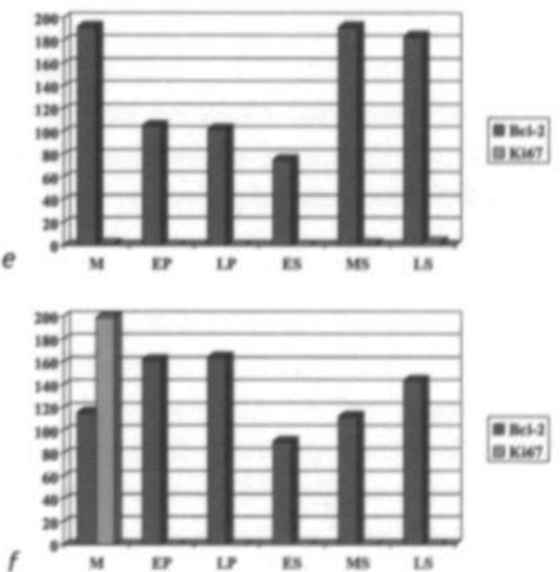

\section{Discussion}

Menstruation, or extensive remodeling of endometrial tissues, occurs at the end of each normal reproductive cycle in women. Many studies have revealed that tissue degradation associated with menstruation is the result of an active process in which apoptosis is involved (5,8-10). Studies performed in vitro and in transgenic mice indicate that $\mathrm{BCl}-2$ could play a role in extending the survival of normal and 
pathologic cells by preventing apoptosis $(5,8-11,15)$. Bcl-2 can inhibit the apoptosis induced by c-myc (1). Hockenbery and coworkers (12) reported the localization of $\mathrm{BCl}-2$ in tissues in which apoptosis occurs, especially glandular epithelium, influenced by hormones and growth factors. The endometrium is acutely responsive to hormonal stimulation, growing and involuting under well-defined hormonal control. Changes are induced by binding of the steroid hormones to their receptors and the subsequent regulation of transcription of the target genes in this tissue. It has been suggested that the $\mathrm{Bcl}-2$ protein is located on the cytoplasmic side of mitochondrial, endoplasmic reticular and nuclear membranes (16); the mode of action and the regulation of $\mathrm{Bcl}-2$ are unclear.

We investigated the expression of $\mathrm{Bcl}-2$ and $\mathrm{Ki}_{7} 7$ in the different phases of the menstrual cycle. $\mathrm{Bcl}-2$ was expressed in all components of the endometrium and myometrium but expression varied throughout the menstrual cycle. $\mathrm{Bcl}-2$ in glandular cells was predominantly expressed at the end of the follicular phase. Bcl-2 expression diminished or even disappeared at the onset of secretory activity. In stromal cells of functional endometrium we saw little $\mathrm{Bcl}-2$ staining in basal endometrium. $\mathrm{Bcl}-2$ was expressed throughout all phases of the menstrual cycle. Myometrial cells stained strongly for $\mathrm{Bcl}-2$ throughout all phases of the menstrual cycle. $\mathrm{Ki}_{7} 7$ was predominantly expressed in glandular epithelial cells, especially in functional endometrium. Tabibzadeh and coworkers (1) reported the same cyclic pattern of $\mathrm{Bcl}-2$ in different cell types. Gompel and coworkers (13) described Bcl-2 expression by immunohistochemical methods in samples of normal endometrium. The pattern of $\mathrm{Bcl}-2$ and $\mathrm{Ki} 67$ staining in glandular and stromal cells in their study varied according to the cell type and the menstrual cycle phase, as they did in our study. Myometrial cells in their study also strongly stained for $\mathrm{Bcl}-2$; the intensity was greater than in endometrium. They reported maximum staining of $\mathrm{Bcl}-2$ and $\mathrm{Ki} 67$ simultaneously for the two proteins in the glandular epithelium, whereas in the preovulatory period the number of Bcl-2-positive cells was far greater than the number of Ki67-positive cells: only some cells stained positively for Ki67, whereas all glandular cells expressed $\mathrm{Bcl}-2$. The aim of our study was not to investigate the coexpression of $\mathrm{Bcl}-2$ and $\mathrm{Ki} 67$, so we stained for $\mathrm{Bcl}-2$ and $\mathrm{Ki}_{7} 7$ in different paraffin sections of the same tissue specimen, but our findings were comparable.

Our study confirms the results of Gompel and coworkers (13) and suggests that $\mathrm{BCl}-2$ expression is inhibited in the glands as soon as progesterone appears, two weeks before the physiologic involution of the endometrium. Recently, Morsi and coworkers (11) also described Ki67 expression in different benign and malignant endometrial conditions. In normal proliferative and secretory epithelial endometrium the results of Ki67 expression were corresponding. They also showed expression of two markers for apoptosis, $\mathrm{Bcl}-2$ and $\mathrm{M}_{30}$, in proliferative, secretory, atrophic and pathologic endometrium (11). In this study, measurements of $\mathrm{Bcl}-2$ expression were restricted to epithelial cells. In confirmation with our results, Morsi and coworkers (11) described the highest expression in basal, compared to functional and superficial endometrial epithelial cells. Besides, in the secretory phases $\mathrm{Bcl}-2$ expression was restricted to the basal layer of the endometrium. In our study this pattern was clearly seen for stromal cells.

Vaskivuo and coworkers (10) showed $\mathrm{BCl}-2$ and $\mathrm{Ki} 67$ expression in endometrial biopsies. High $\mathrm{Bcl}-2$ expression was seen in epithelial cells of the (late) proliferative 
phase; low or absent expression was seen in the secretory phase. In stromal cells, they saw no differences in expression throughout the menstrual cycle. We saw a persistently high expression of $\mathrm{Bcl}-2$ in basal endometrium in contrast to absent $\mathrm{Bcl}$ 2 expression in stromal cells of functional endometrium in almost all phases of the menstrual cycle. The results of the present study agree with their findings of higher expression of Ki67 in epithelial than in stromal cells. Vaskivuo and coworkers (10) also described a decrease in Ki67 expression towards the secretory phase with absence of expression in the late secretory phase. For epithelial as well as for stromal cells, we recognized this pattern more clearly in basal than in functional endometrium. A regular endometrial biopsy, however, mostly consists of only functional endometrium.

Matrix metalloproteinases (MMPs) and their tissue inhibitors are involved in normal tissue remodeling. Their genes are regulated by a number of biologically active factors, including steroid hormones and growth factors $(6,17)$. Production of MMPs increases upon progesterone withdrawal, although there is no effect on their tissue inhibitors. Decrease of progesterone alters the ratio between MMPs and their tissue inhibitors in favor of MMPs. This balance between enzyme production and its specific inhibitors is crucial for menstruation $(6,17)$.

The pattern of regulation of growth and differentiation in stroma is different from that in glandular epithelium: proliferation is maintained in glandular epithelium, directly or indirectly as a paracrine stromal effect, by estradiol; as soon as progesterone is secreted, cell cycle activity (cell proliferation) stops and secretory characteristics appear. In stromal cells progesterone not only controls differentiation but also permits proliferation under the control of growth factors (17). Our results confirm the importance of $\mathrm{Bcl}-2$ in cell survival. A disturbance of the balance between the expression of MMPs, their tissue inhibitors and Bcl-2 expression could lead to tissue disintegration.

Tabibzadeh and coworkers (1) described the induction of apoptosis by antigen exposure, glucocorticoids and cytokines like tumor necrosis factor- $\alpha$ (TNF- $\alpha$ ). In endometrial epithelial and stromal cells TNF- $\alpha$ expression progressively increases in the secretory phase. This coincides with the progressive rise of apoptosis in endometrium. Regulation of apoptosis may be TNF- $\alpha$-dependent, either by the production of TNF- $\alpha$ per se or by the regulation of its receptor. Since the expression of the TNF- $\alpha$ receptor in endometrial epithelium remains constant throughout the menstrual cycle phases, cyclically changing local TNF- $\alpha$ levels appear to be the modulators of apoptosis.

Bcl-2 promotes cell survival by suppressing apoptosis. It protects cells against TNF$\alpha$-induced toxicity. Anti-apoptosis was predominantly seen in the proliferative phases of the menstrual cycle, especially in glandular epithelial cells. Loss of $\mathrm{Bcl}-2$ expression in the secretory phase may make these cells susceptible to signals that lead to cell death. In contrast to this, $\mathrm{Bcl}-2$ expression persists in basal laminal stromal cells, accounting for the low frequency of apoptosis in these cells and thus for the privilege of escaping from apoptosis-inducing signals. They enable the endometrium to repair after menstruation, and proliferation is the result of increasing estradiol concentration, high estrogen receptor expression and growth hormones. After the onset of progesterone production, when MMP levels and TNF- $\alpha$ increase, $\mathrm{Bcl}-2$ levels decrease and androgen receptor expression in stromal cells disappears (18), cell disintegration is inevitable and finally menstruation may occur. 
In stromal cells $\mathrm{Ki} 67$ expression was seen in the proliferative phase of functional endometrium; expression in these cells stays relatively high in the secretory phase. This pattern of expression is consistent with the findings of Shiozawa and coworkers (4). A study by Tabibzadeh and coworkers (19) described Ki67 expression in lymphoid cells of human endometrium, which suggests that restoring of these lymphoid cells after each menstrual period is also due to proliferation.

We can conclude that growth activity in the stromal cells appears to be elevated in both the proliferative and the secretory phase of the menstrual cycle. We see Bcl-2 expression and thus anti-apoptosis and prolonged cell survival in the proliferative phase. In stromal cells of basal endometrium, cell survival based on Bcl-2 expression is guaranteed throughout all phases of the cycle. Growth activity based on Ki67 expression is mostly seen in glandular cells of functional endometrium. In the secretory phase, the expression of $\mathrm{Ki}_{7} 7$ in stromal cells indicates that such cells are involved in growth activity even though progesterone levels are high. When glandular cells are undergoing replication, stromal cells still have growth activity. In the same hormonal milieu stromal or glandular cells respond differently, which is further evidence that stromal cells might have growth-regulating mechanisms different from those of the glandular cells. Simultaneous growth factor and progesterone stimulation may be essential for cyclic changes in endometrial stroma.

\section{References}

1 Tabibzadeh S, Zupi E, Babaknia A, Liu R, Marconi D, Romanini C. Site and menstrual cycle-dependent expression of proteins of the tumour necrosis factor (TNF) receptor family, and $\mathrm{Bcl}-2$ oncoprotein and phase-specific production of TNF alpha in human endometrium. Hum Reprod 1995; 10: 277-280

2 Hopwood D, Levison DA. Atrophy and apoptosis in the cyclical human endometrium. J Pathol 1976; 119: 159-166

3 Rotello RJ, Hocker MB, Gerschenson LE. Biochemical evidence for programmed cell death in rabbit uterine epithelium. Am J Pathol 1989; 134: 491-495

4 Shiozawa T, Li S, Nakayama K, Nikaido T, Fuiji S. Relationship between the expression of cyclins/cyclin-dependent kinases and sex-steroid receptors/Ki67 in normal human endometrial glands and stroma during the menstrual cycle. Mol Hum Reprod 1996; 2: 745-752

5 Koh EAT, Illinworth PJ, Duncan WC, Critchley HOD. Immunolocalization of Bcl-2 protein in human endometrium in the menstrual cycle and simulated early pregnancy. Hum Reprod 1995; 10: 1557-1562

6 Hampton AL, Salamonson LA. Expression of messenger ribonucleic acid encoding matrix metalloproteinases and their tissue inhibitors is related to menstruation. J Endocrinol 1994: 141: 1.3

7 McLaren J, Prentice A, Charnock-Jones DS, Sharkey AM, Smith SK. Immunolocalization of the apoptosis regulating proteins $\mathrm{Bcl}-2$ and $\mathrm{Bax}$ in human endometrium and isolated peritoneal fluid macrophages in endometriosis. Hum Reprod 1997; 12: 146-152

8 Schwartzman RA, Cidlowski JA. Apoptosis: The biochemistry and molecular biology of programmed cell death. Endocr Rev 1993; 14: 133-139

9 Nawaz S, Lynch MP, Galand P, Gerschenson LE. Hormonal regulation of cell death 
in rabbit uterine epithelium. Am J Pathol 1987; 127: 51-59

10 Vaskivuo TE, Stenback F, Karhumaa P, Risteli J, Dunkel L, Tapanainen JS. Apoptosis and apoptosis-related proteins in human endometrium. Mol Cell Endocrinol 2000; $25: 75-83$

11 Morsi HM, Leers MPG, Jager W, Bjorklund V, Radespiel-Troger M, El Kabarity H, Nap M, Lang N. The patterns of expression of an apoptosis-related CK 18 neoepitope, the Bcl-2 proto-oncogene, and the Ki67 proliferation marker in normal, hyperplastic, and malignant endometrium. Int / Gynecol Pathol 2000; 19: 118-126

12 Hockenbery DM, Zutter M, Hickey W, Nahm M, Korsmeyer SI. Bcl-2 protein is topographically restricted in tissues characterized by apoptotic cell death. Proc Nat Acad Sci USA 1991; 88: 6961-6965

13 Gompel A, Sabourin JC, Martin A, Yaneva H, Audouin J, Decroix Y. Bcl-2 expression in normal endometrium during the menstrual cycle. Am J Pathol 1994: 144: 1195-1202

14 Noyes RW, Herig AT, Roch J. Dating the endometrial biopsy. Fertil Steril 1950; 1: 3-10

15 Yamauchi N, Sakamoto A, Uozaki H, lihara K, Machinami R. Immunohistochemical analysis of endometrial adenocarcinoma for $\mathrm{Bcl}-2$ and $\mathrm{p}_{53}$ in relation to expression of sex steroid receptor and proliferative activity. Int J Gynecol Pathol 1996; 15: 202-208

16 Jacobson MD, Burne JF, King MP, Miyashita T, Reed JC, Raff MC. Bcl-2 blocks apoptosis in cells lacking mitochondrial DNA (letter). Nature 1993; 361: 365-368

17 Salamonsen LA, Butt AR, Hammond FR, Garcia S, Zhang J. Production of endometrial matrix metalloproteinases, but not their tissue inhibitors, is modulated by progesterone withdrawal in an in vitro model for menstruation. J Endocrinol Metab 1997; 82: 1409-1415

18 Mertens HJMM, Heineman MJ, Theunissen PHMH, Jong de FH. Androgen receptor content in human endometrium. Eur J Obstet Gynecol 1996; 70: 11-13

19 Tabibzadeh S. Proliferative activity of lymphoid cells in human endometrium throughout the menstrual cycle. J Clin Endocrinol Metab 1990; 70: 437-443 


\section{CHAPTER 4}

Steroid hormone receptor analysis in human endometrium: comparison of immunohistochemistry and flow cytometry

H.J.M.M. Mertens, M.J. Heineman, J.L.H. Evers

Gynecologic and Obstetric Investigation (accepted) 


\section{Abstract}

Of all methods of hormone receptor analysis, single flow cytometry ( $\mathrm{FCM}$ ) of immunofluorescence staining for estrogen receptors (ER), progesterone receptors (PR) and androgen receptors (AR) represents a fast and objective single cell assay. The aim of this study was to develop an assay to quantify the hormone receptor content in a premenopausal and postmenopausal endometrial epithelial cell population by multiparameter flow cytometry.

Steroid receptor content was calculated in endometrial epithelial and stromal cells using immunohistochemistry and multiparameter FCM. Normal endometrium tissue was collected at different phases of the menstrual cycle and after menopause.

Immunohistochemistry and FCM steroid receptor analysis showed an acceptable correlation. The Spearmans' correlation coefficient was 0.60 for ER; 0.50 for PR and 0.78 for AR. The intraclass correlation coefficient was 0.59 for ER; 0.62 for PR and 0.14 for AR. In human endometrial cells ER, PR and AR contents declined from the early proliferative to the late secretory phase. In postmenopausal endometrium ER, $P R$ and $A R$ contents were relatively high.

With multiparameter FCM it is possible to study steroid hormone receptor content in relation to ploidy status and cell cycle parameters in epithelial cells of human endometrium in a sensitive, reliable and less time-consuming way. 


\section{Introduction}

Human endometrium is influenced by estrogens, progesterone and androgens. Estrogens and progesterone affect growth of hormone-dependent cancers like endometrial and breast cancer (1-4). Besides, for understanding cell biology processes and tumor behavior, the growth potential fraction and DNA content of the cell are other important parameters (5-8).

Because the level of estrogen receptor (ER) and progesterone receptor (PR) content are important parameters to predict short-term prognosis and tumor response to endocrine treatment, the analysis of steroid hormone receptors is widely used in the management of endometrial cancers. More recently it has been shown that also the androgen receptor (AR) can be determined in endometrial cells. The relevance of AR content is still subject of many studies.

The expression of ER, PR and AR can be determined either by biochemical assays, i.e. ligand binding assays and immunoassays, or by immunohistochemistry. The heterogeneous nature of tumor samples is presumably one of the main factors responsible for the limited predictive value of receptor assays on homogenised tissue, prepared for e.g. biochemical flow cytometric analysis and for the highly variable ER, $P R$ and AR concentrations that have been reported (2-3).

In many methods of hormone receptor analysis the tissue composition is unknown. Tumor tissue consists not only of tumor cells, but actually contains a mixture of (normal and tumor) epithelial, stromal and infiltrating cells (leukocytes). Many of these cells lack steroid receptors and their presence will produce a contamination or at least an incorrect rate of the determined tissue receptor content.

By immunohistochemistry on paraffin embedded tissues steroid receptor content can be counted separately in the endometrial normal epithelial cells, stromal cells, myometrial cells, blood vessels, endometrial tumor cells. It is a cumbersome method and calculation of the receptor expression would, for that reason, not be performed in routine pathologic examinations.

Single- or multiparameter flow cytometry (FCM) is a faster method of steroid receptor content analysis. Since FCM is performed on a cell by cell basis, a mixture of receptor negative cells added to the tissue cells has no influence on the fluorescence level of individual cells. A simultaneous measurement of the receptor expression and DNA content using flow cytometry offers the advantage of studying the expression of these receptors in relation to growth and DNA ploidy of the tumor. DNA aneuploid tumor cells can be easily recognised in a bivariate hormone receptor/DNA flowcytometric analysis (9-10). Schutte et al (11) described a tricolor flow cytometric staining technique: a combined analysis of cytoplasmic markers (cytokeratin), hormone receptors and DNA may aid not only in the selection of epithelial cells, based on cytokeratin expression, but also in the bivariate analysis of DNA and hormone receptor content. The aim of the present study was to compare the steroid hormone receptor analysis using immunohistochemistry and using multiparameter flow cytometry. 


\section{Material and Methods}

\section{Tissue sampling}

Human endometrium was collected at different menstrual cycle phases $(n=29)$ and after menopause $(n=6)$. All patients were scheduled for hysterectomy because of benign disorders in 1998-1999 in the Atrium Medical Center in Heerlen and did not use exogenous hormonal therapy within 6 months before the operation. All premenopausal patients had a regular menstrual cycle.

Immediately after surgery, the removed uteri were opened and two full-thickness samples, including endometrium and underlying myometrium, were obtained of the midfundus. One specimen was fixed for 24 hours in buffered formaldehyde $(3,7 \%$ ) and processed routinely for paraffin embedding. The other specimen was frozen immediately in liquid nitrogen and stored at $-70^{\circ} \mathrm{C}$. The snap frozen part was used for the flow cytometric analysis while the paraffin embedded part was used for immunohistochemical analysis.

None of the uteri revealed histopathologic abnormalities. The endometrial dating criteria, described by Noyes and coworkers (12) were used to confirm the phase of the menstrual cycle in haematoxylin-eosin stained sections of the midfundus endometrium. The histologic appearance of the endometrium was classified as $M$ : menstruation (days 1-5) $(n=2)$, EP: early proliferative phase (days 6-9) $(n=4)$, LP: late proliferative phase (days 10-14) $(n=6)$, ES: early secretory phase (days 15-18) $(n=4)$, MS: midsecretory phase (days 19-22) $(n=5)$ and LS: late secretory phase (days 23-28) $(n=7)$ or PM: postmenopausal $(n=6)$. Off all specimens the histologic appearance agreed with the date of the last menstrual period.

The Medical Ethical Committee of the Hospital approved the study. Patient consent was obtained.

\section{Multiparameter flow cytometry}

\section{Preparation of the cell suspension}

The specimens intended for flow cytometric analyses were disaggregated mechanically by mincing with scalpel blades after thawing the frozen tissue samples in phosphate buffered saline (PBS, pH 7.2-7.4). Before fixation, the suspension was filtered through a $50-\mu \mathrm{m}$ nylon mesh. The suspension of single cells (approximately $10^{6}$ cells in $100 \mu \mathrm{lPBS}$ ) was aliquoted in $500 \mu \mathrm{l}$ cold lysis buffer, containing PBS, $0.5 \%$ Triton$\mathrm{X}_{100}, 10 \mathrm{mg} / \mathrm{ml}$ bovine serum albumin (BSA; Sigma, St.-Louis, Mo, USA), $0.01 \mu \mathrm{g} / \mathrm{ml}$ EDTA, pH 7.4. After gentle mixing, the cells were kept on ice for 15 minutes. The cells were fixed by adding $3 \mathrm{ml}$ of ice-cold methanol $\left(-20^{\circ} \mathrm{C}\right)$. After 10 minutes of incubation at room temperature the methanol was washed out by centrifugation and the cell pellet was rinsed in PBS, supplemented with $1 \mathrm{mg} / \mathrm{ml} \mathrm{BSA} \mathrm{(BSA/PBS).}$

\section{Immuno- and DNA labeling of the cell suspension}

A double indirect fluorochrome labeled antibody technique with fluorescein isothiothcyanate (FITC)- and r-phycoerythrein (RPE)-conjugated secondary antibody reagents was used. The single cell suspension was aliquoted into $100 \mu$ l samples. To each sample, both primary antibodies were added simultaneously, i.e. the polyclonal rabbit cytokeratin antiserum (1:500; DAKO A/S, Glostrup, Denmark) in combination 
with a monoclonal antibody to one of the steroid hormone receptors: ER ( $1 \mathrm{D}_{5} ; 1: 100$; DAKO), PR (1A6; 1:100; DAKO) or AR (F39.4; 1:100; Biogenex, San Ramon, USA). After incubation at room temperature overnight, the samples were rinsed twice in PBS. Binding of primary antibodies was detected by incubating the cell pellet simultaneously with 2 secondary antibodies; that is goat-anti-mouse immunoglobulin (Ig)-FITC (1:10;DAKO) and goat-anti-rabbit Ig-RPE (1:12; Mannheim, Germany). After incubation for $11 / 2$ hours at room temperature, the samples were rinsed twice in PBS, and finally DNA was stained with propidium iodide ( $\mathrm{Pl} ; 1.0 \mu \mathrm{g} / \mathrm{ml}$; Sigma) in PBS containing $0.1 \mathrm{mg} / \mathrm{ml}$ RNAse (Serva, Heidelberg, Germany).

The samples were allowed to stand for 15 minutes on ice in the dark before FCM analysis. As negative controls for background staining, a cell suspension was simultaneously incubated with mouse monoclonal antiBrdU (IIB5; 1:50; Eurodiagnostica, Arnhem, NL) as a control for the mouse primary antibodies. As a control for the rabbit primary antiserum, a polyclonal antiserum directed against bovin mycobacterium (1:800; DAKO) was used.

\section{Flow cytometric analysis}

All samples were analysed using a FACScan flow cytometer (Becton Dickinson, San Jose, CA, USA). Cells were excited with a single $488 \mathrm{~nm}$ Argon laser. FITC-fluorescence was detected through a 515 to $545 \mathrm{~nm}$ BP-filter, RPE-fluorescence through a $572-588$ $\mathrm{nm}$ BP-filter, and PI fluorescence through a $600 \mathrm{~nm}$ LP-filter. Electronic gating was used to exclude doublets, aggregates and cell debris. At least 20,000 cells were collected for each sample. FITC- and RPE-signals were recorded as logarithmic amplified data, and the PI-signals were recorded as linear amplified data. The following settings were used: $448 \mathrm{~V}, 395 \mathrm{~V}$ and $437 \mathrm{~V}$ on photomultiplier tubes for $\mathrm{FL}_{1}$ (FITC), FL2 (RPE) and $\mathrm{FL}_{3}(\mathrm{PI})$ respectively. Compensation for (FL1-\%FL2), (FL2. $\left.\% F_{3}\right)$, (FL2-\%FL1), (FL3-\%FL2) was $1.1 \%, 39.8 \%, 41.8 \%$ and $8.3 \%$ respectively. Data analysis was performed using LYSIS II software (Becton Dickinson). The number of hormone receptor positive cells was determined in the cytokeratin-positive fraction by an arbitrary setting following $5 \%$ of positive counts in the negative control. The relative fluorescence intensity (RFI) was calculated as the ratio of the mean fluorescence intensity (MFI) of the sample as compared with that of the negative control.

\section{Immunohistochemistry}

In parallel to steroid hormone receptor staining in suspension, consecutive sections of $4 \mu \mathrm{m}$ thick were cut from the corresponding paraffin embedded blocks. They were mounted on 3-aminopropylthriethoxy silane (APES) coated slides and air-dried overnight at $37 \mathrm{oC}$. For immunostaining, these sections were de-waxed, rehydrated and immersed for 10 minutes in methanol with $0,3 \% \mathrm{H}_{2} \mathrm{O}_{2}$ to block endogenous peroxidase activity. The sections were immersed in $0.01 \mathrm{M}$ sodium citrate buffer $\mathrm{(pH}$ 6.o) in a microwave-resistant container, and were then microwaved twice for 5 minutes at 700 Watt. After cooling to room temperature the sections were rinsed in PBS ( $\mathrm{pH} 7.4$ ). All sections were then pre-incubated with $1 \%$ bovine serum albumin in PBS for 15 minutes. The hormone receptors were detected using anti-ER (1D5, DAKO), anti-PR (1A6) and anti-AR (F39.4, Biogenex, San Ramon, USA) at dilution of 1:150, 1:100 and 1:100 respectively. The sections were incubated with the antibodies at room 
temperature overnight.

After rinsing in PBS, sections were incubated with biotin labelled goat-anti-mouse immunoglobulins (DAKO) for 1 hour at room temperature at a dilution of 1:400. After rinsing with PBS, the sections were incubated with streptravidin conjugated with horse radish peroxidase for 1 hour at room temperature (1:600). After washing in PBS, peroxidase activity was detected with 3.3-diamino-benzidine/o.0002 $\% \mathrm{H}_{2} \mathrm{O}_{2}$-solution (Sigma). Finally, the sections were counterstained with hematoxylin, dehydrated, cleared in xylene and mounted in Entellan

The intensity and distribution of staining for $E R, P R$ and $A R$ were evaluated visually semiquantitatively. Classification of staining intensity was assessed on separate cohorts of 100 cells in three different high power fields ( $x 400$ ), allowing assessment of heterogeneity in cell receptor content for a total number of 300 cells.

Assessment of staining intensity profiles was random and blind: the menstrual cycle phase was unknown to the investigator. The intensity of specific staining was evaluated visually using a semiquantitative analysis as described by McCarty and coworkers (13), as follows:

\begin{tabular}{|c|c|}
\hline & $i=4$ \\
\hline receptor score $=$ & $\sum P_{(i)} \times i$ \\
\hline
\end{tabular}

where $i$ is intensity of staining, ranging from 0 (no staining) to 4 (very intense staining), and $\mathrm{P}(\mathrm{i})$ is percentage of cells stained with intensity $i$. The final receptor score is obtained by calculating the sum of the specific staining of the three cohorts.

\section{Statistical analysis}

To evaluate both methods of hormone receptor analysis we used the Spearmans' correlation coefficient. A correlation is significant at the 0.05 level. In methodcomparison studies also the intraclass correlation coefficient (ICC) has been described (14). The ICC is the proportion of total variability among subjects and has to be used when a 'golden standard method' is lacking and results of both methods have different outliers. The ICC measures what proportion of variation is explained by the between subject variation. A high ICC means that not much of the variability is due to variability in measurement on different occasions. The ICC varies from o to 1.

\section{Results}

When the cell suspensions were examined by fluorescence microscopy it became evident that the immunostaining for ER, PR and AR was localised exclusively in the nucleus. Furthermore, the epithelial cells had retained enough cytoskeletal remnants around the nucleus to allow immunocytochemical detection of cytokeratin filaments. The hormone receptor positive cells showed a strong staining after overnight incubation with the antibodies directed against ER, PR and AR compared to a short incubation of 1 hour (unpublished observation). Cell permeabilization with detergent (Triton X-100) proved essential in order to provide a reproducible immunofluorescence signal for the hormone receptors. 
ER contents measured by both methods of receptor analysis (immunohistochemistry as well as flowcytometry), at the various phases of the menstrual cycle and in postmenopausal endometrium, are shown in figure 1. ER in endometrial epithelial cells was high in the early and late proliferative phase and gradually decreased during the secretory phases. ER content in endometrial stomal cells was not clearly changing throughout all menstrual cycle phases and in postmenopausal endometrial cells (figure 2).

Figure 1,3.5 Estrogen, Progesterone and Androgen receptor expression

Estrogen receptor (ER), Progesterone receptor (PR) and Androgen receptor (AR) content is measured using immunocytochemistry (IHC) and flow cytometry (FCM). Steroid receptor content measured by IHC is shown by diamonds; steroid receptor content measured by FCM is given by bars during all phases of the menstrual cycle and after menopause (menstruation phase (M), early proliferative phase (EP), late proliferative phase (LP), early secretory phase (ES), mid secretory phase (MS), late secretory phase (LS), postmenopausal (PM)).

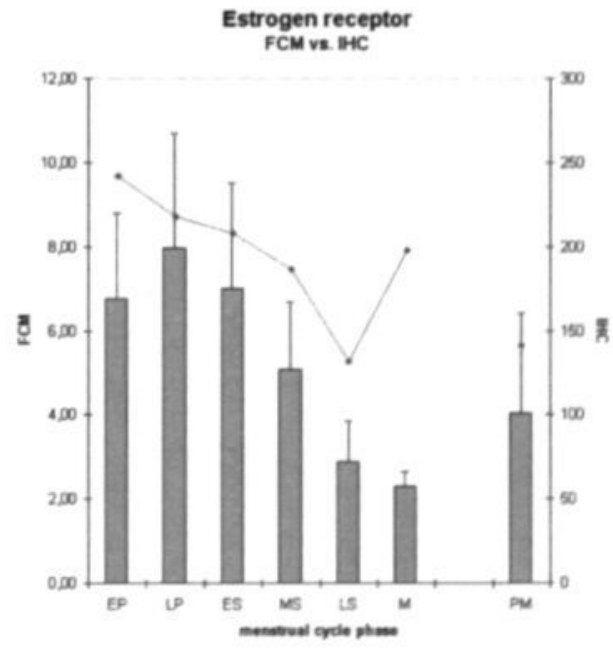



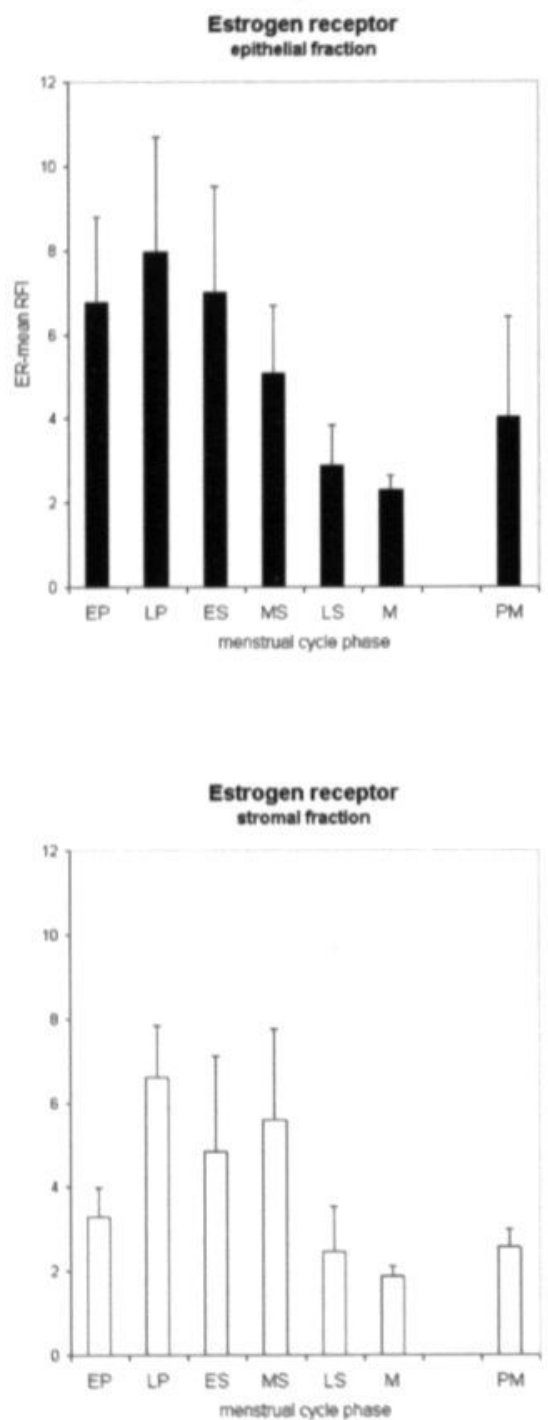

The expression of PR measured by both methods of analysis is shown in figure 3. PR expression of the cytokeratin positive and negative cells were strong during the proliferative phases, reaching a maximum in the late proliferative and early secretory phases (figure 4 ). In the mid- and late secretory phases, PR expression declined sharply. 
Progesterone receptor

FCM va IAC

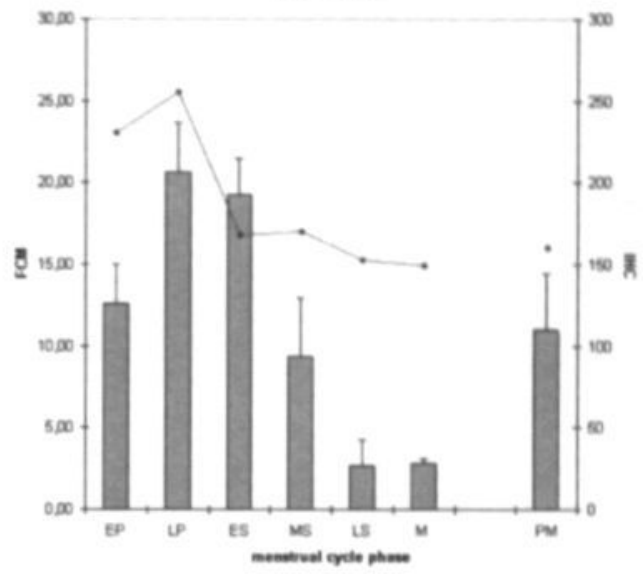

Progesterone receptor

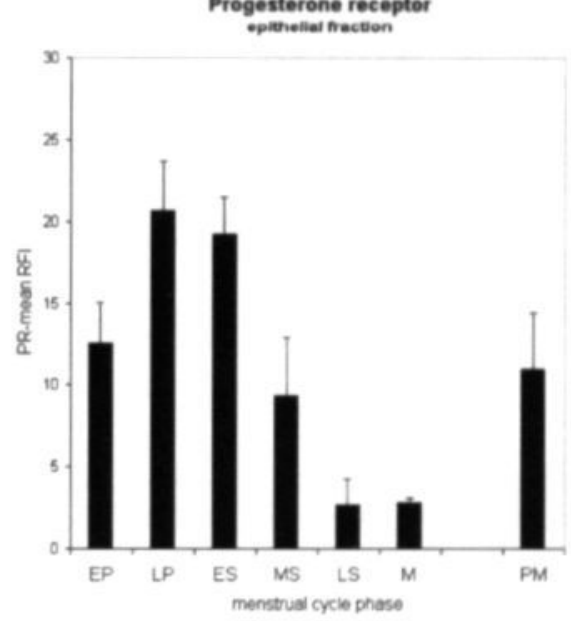

Progesterone receptor

stromal fraction

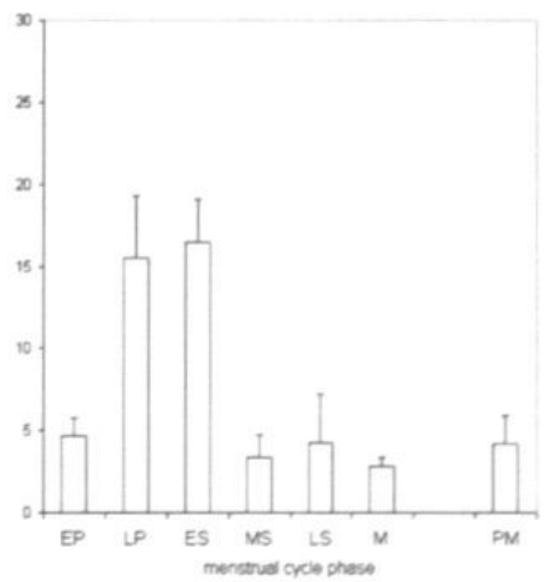


AR content measured by both methods of receptor analysis at the different menstrual cycle phases and in postmenopausal endometrium is shown in figure 5 . AR expression in endometrial stromal cells decreased from the proliferative phases to the early and late secretory phases. In the mid secretory phase AR content was higher than in the early and late secretory phases, but lower than in the proliferative phases (Figure 6). In the late secretory phase AR was hardly seen by immunohistochemical analysis. AR content in postmenopausal endometrial cells was relatively higher, especially in endometrial epithelial cells.
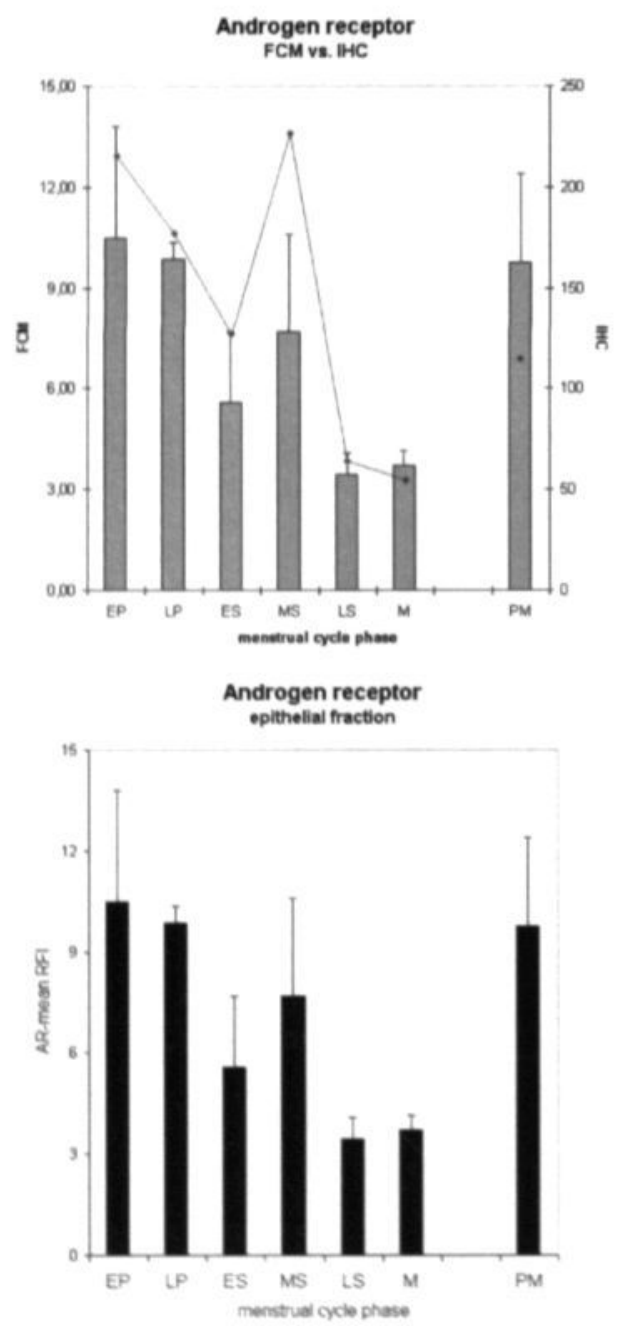


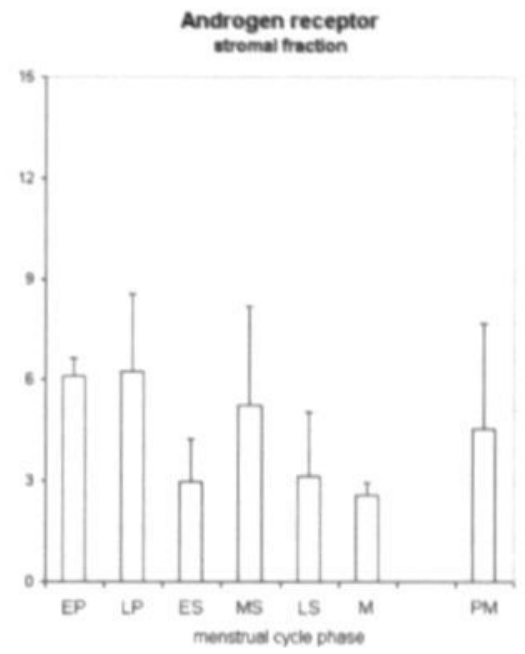

Figure 2,4,6 Estrogen, Progesterone, Androgen receptor expression: epithelial and stromal fraction

Estrogen, Progesterone and Androgen receptor content measured in epithelial cells (left) and stromal cells (right) of human endometrium. Steroid hormone receptor content is given in all phases of the menstrual cycle and after menopause (menstruation phase (M), early proliferative phase (EP), late proliferative phase (LP), early secretory postmenopausal (PM)).

To evaluate both methods of hormone receptor analysis (figure 1,3.5) we calculated the Spearmans' correlation coefficient. This correlation for ER was 0.60 ; for PR 0.50 ; and for AR 0.78 . The ICC for both methods of steroid receptor analysis (IHC versus FCM) was performed: the ICC for ER, PR and AR was $0.59,0.62$ and 0.14 respectively.

\section{Discussion}

The only way to analyse receptor expression was the semiquantitative counting method. With advances in biomedical technology, easier, faster and perhaps more reproducible methods for diagnosis and therapy are increasingly replacing the old ones. Many examples of method-comparison studies can be found in the literature involving such diverse equipment as visual acuity test charts (15).

Results of the present study show that hormone receptor FCM analysis on fresh, frozen tissue of endometrium is comparable to steroid receptor content achieved by conventional immunohistochemical assays in endometrial cells. The quantitative correlations show that the steroid hormone receptor analyses correlate well, so flow cytometry can be reliably used as a method for steroid hormone receptor analyses. High agreement between subjects will lead to a high ICC (24) as we saw in the present study for ER and PR. The ICC for AR is lower which may be explained by an incorrect 
or not-reproducible method for AR content (IHC and/or FCM). There is also another explanation for the lower ICC for AR compared to the ICC for other steroid receptors. In several phases of the menstrual cycle AR expression using immunohistochemistry was absent or very low. Using multiparameter FCM AR could be detected in all phases of the menstrual cycle, also at very low level. ER and PR expression were consistently positive. Because the high incidence of negative results for AR expression using immunohistochemistry instead of AR expression using FCM may explain the relatively low ICC (and though the relatively high r). Multiparameter FCM seems to be a more sensitive method for measuring AR expression, whereas very little AR expression can be detected. Although the ICC for AR is relatively low we prefer multiparameter FCM for measuring the expression of AR because of its sensitivity and the same favourable reasons as given above (ER and PR expression).

$E R, P R$ and $A R$ expression are shown in figure 1,3.5. Steroid receptor expression showed the characteristic cyclic pattern according to our and other earlier investigations (15-17). During the proliferative phases ER and PR expression increased in human endometrial epithelium with a decline in receptor expression during the sarratons phases. AR content decreased durine the menstrual cvcle phases. The persistence of the PR expression in the cytokeratin positive fraction during the early secretory phase is consistent with progesterone action. The increase of ER and PR during the proliferative phases probably results from local estradiol concentrations. Although the most intense staining for ER and PR was observed in the late proliferative phase, the intensity of immunostaining for PR was noticeably stronger than that for ER as reflected by a larger relative fluorescence intensity (see figure 1). This was also described by Press and coworkers (16-17) who explained this by the fact that these cells had a greater content of PR (determined by steroid-binding assays and expressed in femtomoles) than of ER.

\section{Acknowledgements}

The authors would like to thank dr. A.F.M.P. de Goeij for critically reading the manuscript.

\section{References}

1 Chambers IT, Carcangiu ML, Voynick IM, Schwartz PE. Immunohistochemical evaluation of estrogen and progesterone receptor content in 183 patients with endometrial cancer. Part II: Correlation between biochemical and immunohistochemical methods and survival. Am J Clin Pathol 1990; 94 : 255. 260

2 Kauppila A. Estrogen and progesteron receptors as prognostic indicators in endometrial cancer. Acta Oncol 1989; 28: 561-566

3 Merkel DA, Osborne CK. Use of steroid receptor assays in cancer management. Rev Endocrinol Rel Cancer 1988; 30: 5-12

4 Nicholson RI, McClelland RA, Gee JMW. Steroid hormone receptors and their clinical significance in cancer. I Clin Pathol 1995; 48: 890-895

5 Hedley DW, Clark GM, Cornellisse CI, Killander D, Kute T, Merkel D. Consensus review of the clinical utility of DNA cytometry in carcinoma of the breast. 
Cytometry 1993; 14: 482-485

6 Klijn JG, Berns EM, Foekens JA. Prognostic factors and response to therapy in breast cancer. Cancer Surv 1993; 18: 165-98

7 Arnesson LG, Smeds S, Hatchek T, Nordenskjold B, Fagerberg G. Hormone receptors, ploidy and proliferation rate in breast cancers up to $10 \mathrm{~mm}$. Eur I Surg Oncol 1992; 18: 235-40

8 Stal O, Dufmats M, Hatchek. S-phase fraction is a prognostic factor in stage I breast carcinoma. I Clin Oncol 1993; 11: 1717-22

9 Leers MPG, Theunissen PHMH, Schutte B, Ramaekers FCS. Bivariate cytokeratin/DNA flow cytometric analysis of paraffin embedded samples from colorectal carcinomas. Cytometry 1995; 21: 101-107

10 Leers MPG, Schutte B, Theunissen PHMH, Ramaekers FCS, Nap M. Heat pretreatment enables high resolution DNA flow cytometry of paraffin embedded tumor tissue. Cytometry 1999; 35: 260-266

11 Schutte B, Tinnemans MMFJ, Pijpers GFP, Lenders MHJH, Ramaekers FCS. Three parameter flow cytometric analysis for simultaneous detection of cytokeratin,

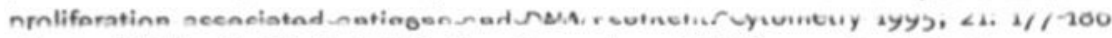

12 Noyes RW, Hertig AT, Rock J. Dating the endometrial biopsy. Fertil Steril 1950; 1: 3-10

13 McCarty KS Jr, Miller LS, Cox EB, Konradt J, McCarty KS Sr. Estrogen receptor analyses: correlation of biochemical and immunohistochemical methods using monoclonal antireceptor antibodies. Arch Pathol Lab Med 1985; 109: 716-721

14 Lessey BA, Killam AP, Metzger DA, Haney AF, Greene GL, McCarty Jr KS. Immunohistochemical analysis of human uterine estrogen and progesterone receptors throughout the menstrual cycle. J Clin Endocrinol Metab 1988; 67: 334 340

15 Snijders MPML, Goeij de AFPM, Debets-Te Baerts MJ, Rousch MJM, Koudstaal Joh, Bosman FT. Immunocytochemical analysis of oestrogen receptors and progesterone receptors in the human uterus throughout the menstrual cycle and after menopause. J Reprod Fert 1992; 94: 363-371

16 Press MF, Nousek-Goebl NA, Bur M, Greene GL.: Estrogen receptor localisation in the female genital tract. Am J Pathol 1986; 123: 280-292

17 Press MF, Udove JA, Greene GL. Progesterone receptor distribution in the human endometrium. Am J Pathol 1988; 131: 112-124

18 Shaw DE, Jones HS, Moseley MJ. Analysis of method-comparison data. Ophthal Physiol Opt 1994, 14: 92-96

19 Prieto L, Lamarca R, Casado A, Alonso J. The evaluation of agreement on continuous variables by the intraclass correlation coefficient. Letters, Book reviews, 1997, 6: 579-581 


\section{CHAPTER 5}

\section{Multiparameter flowcytometry in the diagnosis of a gynaecologic double tumor: a case report}

H.J.M.M. Mertens, M.P.G. Leers, M. Nap, T.H.B. Salemans

Virchows Archiv, An International Journal of Pathology (accepted) 


\section{Abstract}

An uncommon clinical presentation of metastatic tumor will often lead to additional diagnostic examinations. The patient of the present study was known with endometrial cancer which was thought to be limited to the endometrium. Three months postoperative she developped ascites due to spread of tumor which is rarely seen in low stage endometrial cancer.

Multiparameter flowcytometry using both cell phenotype information and DNA ploidy was performed.

Retrospectively, the patient was diagnosed having a DNA-diploid epithelial tumor of the endometrium besides a DNA-aneuploid epithelial tumor in the left fallopian tube. It was shown that three months after primary surgery she developped ascites caused by metastatic tumor from the primary fallopian tube cancer.

The complete diagnosis was made using multiparameter flowcytometry that at present is not routinely applied in gynaecologic pathology. 


\section{Abstract}

An uncommon clinical presentation of metastatic tumor will often lead to additional diagnostic examinations. The patient of the present study was known with endometrial cancer which was thought to be limited to the endometrium. Three months postoperative she developped ascites due to spread of tumor which is rarely seen in low stage endometrial cancer.

Multiparameter flowcytometry using both cell phenotype information and DNA ploidy was performed.

Retrospectively, the patient was diagnosed having a DNA-diploid epithelial tumor of the endometrium besides a DNA-aneuploid epithelial tumor in the left fallopian tube. It was shown that three months after primary surgery she developped ascites caused by metastatic tumor from the primary fallopian tube cancer.

The complete diagnosis was made using multiparameter flowcytometry that at present is not routinely applied in gynaecologic pathology. 


\section{Preparation of cell suspension}

Two fifty $\mu \mathrm{m}$ thick sections were cut from each paraffin block. Subsequently, these tissue sections were deparaffinized twice in xylene, 30 minutes each, and then rehydrated in a descending ethanol series. Sections were then rinsed in phosphate buffered saline (PBS; pH 7.2-7.4). The sections were placed in a glass tube with cold citrate solution ( $2 \mathrm{mg}$ citric acid/ml aqua dest; $\mathrm{pH} 6.0$ ), and then subjected to a 120 minute heating step in an $80^{\circ} \mathrm{C}$ water bath. After a short cooling down period, a 10 minute mild pepsin digestion step followed, at $37^{\circ} \mathrm{C}$ in a freshly prepared solution containing $1 \mathrm{mg} / \mathrm{ml}$ pepsin (Sigma, ST.-Louis, MO, USA) in $0.1 \mathrm{~N} \mathrm{HCl}$. A single cell suspension was obtained by vortexing and filtration of the sample through a $50 \mu \mathrm{m}$ mesh nylon filter. The cell suspension was then centrifuged at $400 \mathrm{G}$ and the cell pellet was resuspended in PBS, supplemented with $1 \%$ bovine serum albumin (BSA/PBS buffer; Sigma).

\section{Multiparameter flow cytometry}

The single cell suspension was aliquoted into $100 \mu \mathrm{l}$ samples. The samples were incubated with a single monoclonal antibody directed to CK 7 (OV/TL 12-30; DAKO ASS, Glostrup, Denmark; 1:50), CK 20 (Ks2o.8; DAKO; 1:50) or pan-CK (MNF116; DAKO; 1:50). After an overnight incubation at room temperature, antibody binding was made visible by incubating the single cells with FITC labeled goat-anti-mouse Ig (DAKO AVS; 1:10) for 1.5 hours at room temperature. The samples were rinsed in PBS two times and finally DNA was stained using propidium iodide (PI, 1.0 $\mu$ Sigma) in PBS containing $0.1 \mathrm{mg} / \mathrm{ml}$ RNAse (Serva, Heidelberg, Germany). The samples were allowed to stand for minimal 1 hour in the dark at $4^{\circ} \mathrm{C}$ before flow cytometric analysis. As a negative control for background staining by the primary antibody, a proportion of the cell suspension was incubated with a non-relevant mouse Ig (DAKO; 1:50).

Samples were analyzed using PARTEC PAS III flow cytometer (Partec GmbH, Münster, Germany). Cells were excited with a single $488 \mathrm{~nm}$ argon laser. FITC-fluorescence was detected through a 515-545 nm BP filter and PI-fluorescence through a $600 \mathrm{~nm}$ LP filter. At least 10000 relevant events were collected for each sample. FITC-signals were recorded as logarithmic amplified data, while the PI-signals were recorded as linear amplified data. The following settings were used:

$512 \mathrm{~V}$ and $438 \mathrm{~V}$ on photomultiplier tubes for $\mathrm{FL}_{1}$ ( $\mathrm{FITC}$ ) and $\mathrm{FL}_{3}(\mathrm{PI})$, respectively. Compensation was performed afterwards during analysis by using the $\mathrm{N}$-color compensation module of the PAS software program (Partec $\mathrm{GmbH}$, Münster, Germany). The lack of a known DNA-diploid reference population in nuclei from paraffinembedded tissues makes the identification of these population difficult. Because the incidence of tumors with a DNA-index smaller than 1.0 is rare, it is established in a DNA cytometry consensus conference that it is recommended that the first peak in the DNA histogram may be assumed to represent the DNA-diploid population (4). DNA histograms with a coefficient of variation of the $\mathrm{Go}_{0} / \mathrm{G}_{1}$ peak less than $5 \%$ were considered as good quality measurements. 
Figure 1 DNA histograms of tumor cells of the endometrial cancer, the fallopian tube cancer and cells in the ascites.
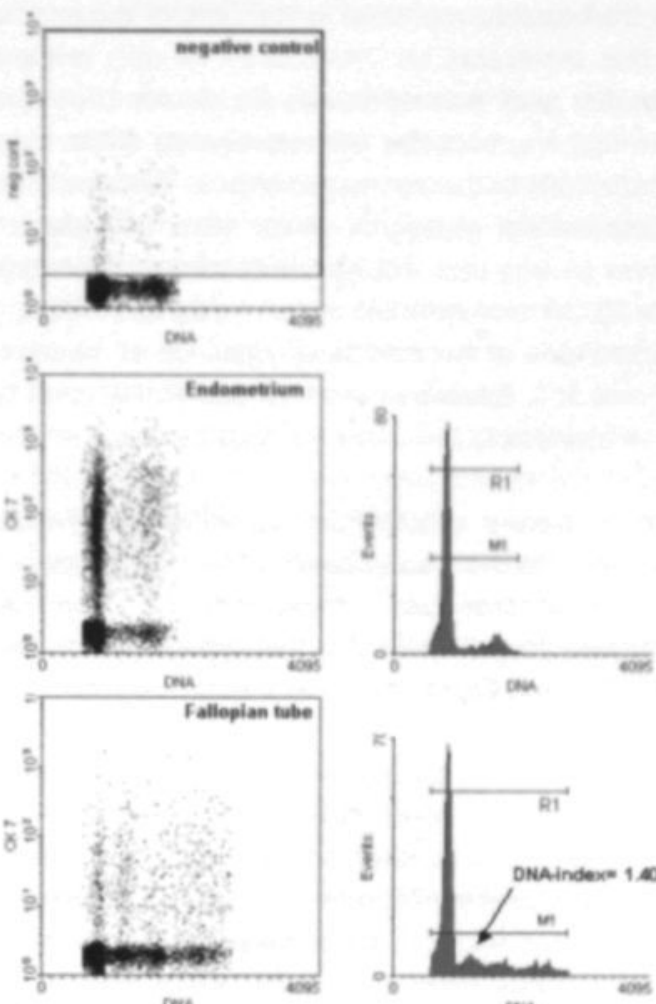

cans
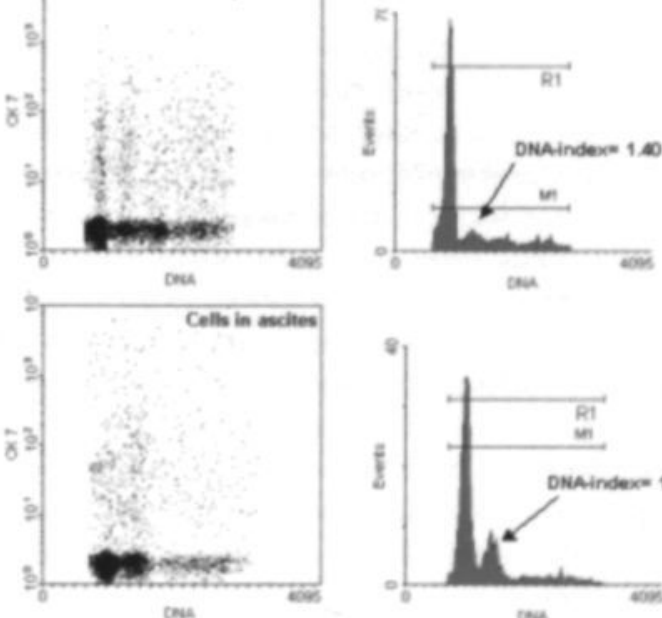

tau

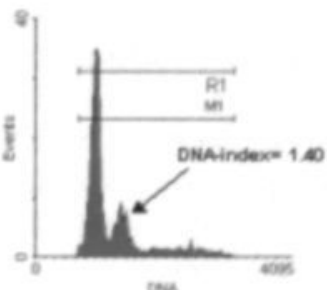

wu.

\section{Legend Figure 1}

Shown in this figure are the dotplots (left panel) and the DNA-histograms (right panel) of the multiparameter cytokeratin/DNA FCM analyses of the endometrium, fallopian tube and cells in the ascites of the patient. In the upper row the negative control corresponding to these analyses is shown. The measurements were performed exclusively in the gate of the cytokeratin positive cells. Analysis of the endometrium showed a normal diploid DNA content.

An additional high $\mathrm{Go}_{\mathrm{O}} \mathrm{G}_{1}$ peak with the accompanying lower $\mathrm{G}_{2} / \mathrm{M}$ peak in the tumor cells of the fallopian tube and cells in the ascites reflect abnormal DNA content in both types of tumor cells. The DNA-content from the (normal) diploid $\mathrm{Go}_{\mathrm{G}} \mathrm{G}_{1}$ peak in both types of tumor cells is the same (DNA-index $=1.40$ ). 


\section{Pathologic findings}

A (normal) diploid DNA pattern was seen in the cells of the endometrial carcinoma: a single large peak that represents $2 \mathrm{~N}$ DNA-content of cells in the $\mathrm{Go}_{\mathrm{O}} \mathrm{G}_{1}$ phase of the cell cycle; and a smaller peak that represents the double DNA-content $(4 \mathrm{~N})$ of cells in the $\mathrm{G}_{2} / \mathrm{M}$ phase. In figure 1, both the DNA-histograms of the tumor mass in the left fallopian tube and the cells in the ascites are shown. Both are different from the DNAhistogram of the endometrial carcinoma. These latter DNA patterns are aneuploid in both cases: they show an extra peak that represents cells with DNA-content of $1.4 \times 2 \mathrm{~N}$.

The DNA-histogram of the endometrial cancer shows two different stemlines; one at the distance of 1 and one at an additional distance at 1.4. The DNA index in the endometrial carcinoma is 1 . The tumor mass of the left fallopian tube and the cells in the ascites show an abnormal DNA index. In both tumors the DNA-index is 1.4 .

We concluded that our patient initially had two primary tumors simultaneously: both endometrial cancer and fallopian tubal cancer. The DNA index of the malignant cells in the ascites and the fallopian tubal cancer were the same; the DNA index of the endometrial cancer mass was different. For that reason cells in the ascites most likely originate from the primary fallopian tube carcinoma.

\section{Discussion}

The woman of the present study originally complained of postmenopausal bloodloss. In about $10-20 \%$ of women with postmenopausal bloodloss, the bleeding is caused by malignancies of the reproductive tract. Endometrial cancer is involved in $12-15 \%$ of these situations (1). It is the most common gynecologic malignancy in developed countries in women between 50-70 years of age. With increasing age, it is more likely that postmenopausal bleeding is caused by endometrial cancer (2).

Endometrial cancer can be histologically classified as either low, intermediate or high grade with different histological subtypes. In this specific case, the endometrial tumor was classified as an adenosquamous carcinoma, which is a combination of high grade adenocarcinoma components, mixed with areas of squamous differentiation.

Staging of the disease is done according to the FIGO system. Endometrial cancer usually spreads along the surface of the endometrium, infiltrates myometrium to the peritoneum and parametria and eventually spreads through the lymphatic veins or blood vessels. It may also spread via the fallopian tubes to the ovaries or peritoneal cavity (1).

Because spread of endometrial cancer is known to be a growth process per continuitatem, the initial remark in the pathology report of a tumor focus in the left fallopian tube should have been reason for further investigations. The unexpected early presentation of peritoneal tumor metastasis in this patient lead to further investigations of the original specimen, in comparison with the present tumor born ascites. Histological review showed that the tumor focus in the fallopian tube was part of the surface lining and not a luminal tumor fragment. Besides, there was infiltration present of the supporting stroma. Rules for classification of fallopian tube cancer have recently been rewritten, according the FIGO Committee of Gynaecologic Oncology (5). 
This observation and the way of tumor spread, made a stage I adenosqamous carcinoma of the endometrium unlikely. However, merely histologic examination did not prove the focus of tumor in the fallopian tube and the endometrium to be two different processes.

Other techniques, such as immunohistochemistry of steroid receptor in the endometrial and tubal carcinoma were incapable of further discrimination as well, which showed the same receptor expression pattern for both tumors. Both tumor locations originate from the same Mullerian epithelium, giving rise to similar phenotypic tumor cell characteristics (6-7).

Flow cytometry can be used to analyze the DNA content of individual cells. In the past, this technique could be applied with confidence to either cells from cultures or single cells prepared from fresh tissue or frozen tissue (3). The use of formalin fixed material suffered from loss of cell surface antigens and unstable DNA analysis.

Recently, a technical modification was described in which the preparation of single cell suspensions from formalin fixed, paraffin embedded material, could be made successfully without loss of antigenity, with high cell recovery and with DNA histograms of perfect quality (3). By using this approach it is also possible to selectively label epithelial cells in a subpopulation of interest $(3,8)$. By this method it was possible to compare cells from both histological sections with cells from the ascites.

In the present study, the diploid DNA index of the endometrial tumor location was in sharp contrast with the aneuploid DNA index of 1.4 , both in the tubal focus and in the malignant cells in the ascites. The absence of even a small aneuploid peak in the endometrial tumor is in favor of two different tumor processes. Since we could demonstrate a similar DNA content in the fallopian tubal cancer and in the malignant cells in the ascites, the latter cells are suggested to be metastases originating from the primary fallopian tube carcinoma.

Metastatic cells not always retain the DNA profile of their primary tumor, but the majority of all metastases show the same profile as the primary tumor (9-10). Studies that describe a different DNA content in metastases and in the primary tumor are predominantly based on uniparameter flow cytometry. Contamination of these samples with normal cells (inflammatory cells, stromal components etc.) may mask small DNA index abnormalities as a not observable aneuploid DNA peak. Using multiparameter flowcytometry with cytokeratin cell labeling, we specifically select tumor cells. Measurements in selected populations represent better tumor cell DNA content.

Primary fallopian tube carcinoma comprises only $0.3-1.1 \%$ of all gynaecologic malignancies $(6,11-14)$. The differentiation between primary malignant tumors of the fallopian tube and metastatic tumor masses is often difficult because of widespread disease (13-15). Tumor masses in the fallopian tube are generally metastatic from the ipsilateral ovary, which has been spread by direct invasion or from a contralateral ovary by transcoelomic spread (11-12,16-17). Primary adenocarcinoma of the fallopian tube with papillary features as seen in this patient, is the most common histological type of primary tube cancer ( $190 \%)(7-8,12-13,16-17)$.

Primary tube cancer is treated like ovarian cancer: one should try to debulke completely. Adjuvant multichemotherapy with a cisplatinum combined treatment 
should be given after surgery $(6,12-16,18-19)$. The patient of the present study received $175 \mathrm{mg} / \mathrm{m}^{2}$ taxol and $75 \mathrm{mg} / \mathrm{m}^{2}$ cisplatinum four months after primary surgery. After four doses chemotherapy was stopped because of progressive disease and nine months after primary surgery she died; autopsy was not allowed.

Correct pre- or peri-operative diagnosis of primary tube cancer is uncommon $(11,15,17)$. Difficulties in diagnosing primary tube cancer exist due to its rarity, the complaints and clinical features are not specific $(11,16)$. Because of these difficulties in diagnosing primary fallopian tubal cancer, a delay in treatment is not uncommon (16). This new histopathologic technique which is recently more feasible in normal practice, enables early correct diagnoses in uncommon clinical or histopathologic manifestations of well-known primary tumors.

\section{References}

1 Copeland LJ. Update on endometrial cancer. Clin Obstet Gynecol 1996; 39: 627$629,656-669,686-728$

2 Schaafsma HE, Ramaekers FCS. Cytokeratin subtyping in normal and neoplastic epithelium: basic principles and diagnostic applications. Pathol Annual 1994; 29: 21.62

3 Leers MPG, Schutte B, Theunissen PHMH, Ramaekers FCM, Nap M. Heat pretreatment enables high resolution DNA flow cytometry of paraffin embedded tumor tissue. Cytometry 1999: 35: 260-266

4 Shankey TV, Rabinovitch PS, Bagwell B, Bauer KD, Duque RE, Hedley DW, Mayall BH, Wheeless L. Guidelines for implementation of clinical DNA cytometry. Cytometry 1993; 14: 472-477

5 FIGO Committee on Gynecologic Oncology. Cancer of the Fallopian Tube. Int J Gynecol Obstet 2000; 70: 209-262

6 Alvarado-Cabrero I, Young RH, Vamvakas EC, Scully RE. Carcinoma of the fallopian tube: a clinical pathological study of 105 cases with observations on staging and prognostic factors. Gynecol Oncol 1999; 72: 367-379

7 Navani SS, Cabrero I, Young RH, Scully RE. Endometrioid carcinoma of the Fallopian tube: a clinicopathologic analysis of 26 cases. Gynecol Oncol 1996; 63: $371 \cdot 378$

8 Hellstrom A. Primary fallopian tube cancer: a review of the literature. Med Oncol 1998; $15: 6-14$

9 Smit VT, Fleuren GJ, van Houwelingen JC, Zegveld ST, Kuipers-Di NJ, Cornelisse C]. Flow cytometric DNA ploidy analysis of synchronously occurring multiple malignant tumors of the female genital tract. Cancer 1990; 66: 1843-1849

10 Zangwill BC, Balsara G, Dunton C, Varello M, Rebane BA, Hernandez E, Atkinson BF. Ovarian carcinoma heterogeneity as demonstrated by DNA ploidy. Cancer 1993: 71: 2261-2267

11 Borghi L, Ballotta MR, Bianchini E, Garavello B, Bononi A, Fortini RM. Primary carcinoma of fallopian tube: experience of six cases. Eur J Obstet Gynecol Reprod Biol 1994: 57: 161-166

12 Friedrich M, Heinsen C, Schweizer J, Hollander M, Stieber M, Schmidt WI. Primary tubal carcinoma: a retrospective analysis of four cases with a literature review. 
Eur J Gynaec Oncol 1998; 19: 138-143

13 Jeregzek B, Jessem J, Kobierska A. Primary cancer of the fallopian tube, report of 26 patients. Acta Obstet Gynecol Scand 1996; 75: 281-286

14 Wang PH, Yuan CC, Chao HT, Juang CM, Ng HT. Prognosis of primary fallopian tube adenocarcinoma: report of 25 patients. Eur J Gynaec Oncol 1998; 6: 571. 574

15 Daskalakis G, Kiosses E, Katsetos C, Petrogiannis N, Michalas S. Primary carcinoma of the fallopian tube. Eur J Gynaec Oncol 1998; 19: 384-385

$16 \mathrm{Ng}$ P, Lawton F. Fallopian Tube Carcinoma - a Review. Annals Academy of Medicine 1998; 27: 693-697

17 Pai RR, Sahu KK, Raghuveer CV. Primary carcinoma of the fallopian tube. A clinicopathologic study. Indian J Cancer 1996; 33: 92-96

18 Cormio G, Gabriele A, Maneo A, Marzola M, Lissoni A, Mangioni C. Second-look laparotomy in the management of fallopian tube carcinoma. Acta Obstet Gynecol Scand 1997; 76: 369-372

19 Rauthe G, Vahrson HW, Burkhardt E. Primary cancer of the fallopian tube. Treatment and results of 37 cases. Eur J Gynaec Oncol 1998; 19: 356-362 
CHAPTER 6

\section{Steroids in postmenopausal women with and without endometrial cancer}

H.J.M.M. Mertens, M.J. Heineman, F.H. de Jong, J.L.H. Evers (submitted) 


\section{Abstract}

The steroidogenic potential of postmenopausal ovaries predominantly consists of the production of androgens, which may be converted peripherally to estrogens. We investigated steroid concentrations in serum from a peripheral antecubital vein and from the utero-ovarian venous plexus in 90 postmenopausal women with and 19 postmenopausal women without endometrial cancer.

Peripheral concentrations of estrone (E1), 17ß-estradiol (E2), testosterone (T), androstenedione (A), sex hormone binding globuline (SHBG) and dehydroepiandrosterone sulphate (DHEAS) did not differ significantly between patients with and without endometrial cancer. Local utero-ovarian vein concentrations of $T$ and $A$ were significantly higher than peripheral concentrations of $T$ and $A$. Local and peripheral $E_{1}$ and $E_{2}$ concentrations did not differ significantly. Only $T$ in the utero-ovarian plexus was significantly higher in patients with than in patients without endometrial cancer; this was the case for the total, free and non-SHBG bound androgen.

The development of endometrial cancer is influenced by steroids. Results from the present study suggest a direct or indirect role of androgens in the pathogenesis or development of endometrial cancer. Therefore, the relationship between androgens and the aetiology of endometrial cancer should be investigated. 


\section{Introduction}

After menopause, ageing ovaries continue to be a source of androgens. Histochemical evidence has become available of persistent steroidogenesis after menopause in hilus cells and stromal theca cells of postmenopausal ovaries (1). The steroidogenic potential of postmenopausal ovaries predominantly consists of the production of testosterone $(T)$ and androstenedione (A) $(2,3)$, which androgens may be converted to estrogens in peripheral nonglandular tissue. The degree of stromal hyperplasia in postmenopausal ovaries correlates significantly with the ovarian vein levels of $T$ and $A(A)$.

Steroids can induce endometrial expression of various growth and angiogenic factors and stimulate cell proliferation. Dysregulation of these steroid-modulated effects has been suggested to be involved in the pathogenesis of endometrial diseases. The persisting hormone production by postmenopausal ovaries may be linked to the development of endometrial cancer.

To determine the effect of postmenopausal ovarian steroid production on endometrium, we investigated steroid levels in postmenopausal women with and without endometrial cancer. We measured steroids in antecubital blood, reflecting the total of hormone biosynthesis in ovaries, adrenal glands and extraglandular sites and in blood sampled from the utero-ovarian venous plexus (5) to selectively evaluate the ovarian endocrine function. Finally, since effects of sex steroids are dependent on the non-protein bound fraction, which can diffuse freely from the vascular compartment into the target cells, we estimated levels of the main sex steroid binding protein sex hormone binding globulin (SHBG) and calculated free and non-SHBG bound concentrations of $\mathrm{T}$ and $17 \beta$-estradiol (E2) in these samples.

\section{Materials and Methods}

\section{Patients}

Blood was sampled in 109 postmenopausal patients: 90 underwent an abdominal hysterectomy with oophorectomy because of endometrial cancer; 19 underwent a laparotomy because of benign gynaecologic conditions.

All patients were postmenopausal, i.e. more than 12 months after their last menstrual period. None of them used hormonal replacement therapy or other steroid medication. All patients had macroscopically normal ovaries.

The Hospital Medical Ethical Committee approved the present study. Patient consent was obtained.

\section{Sampling procedure}

Blood was sampled from an antecubital vein and from the utero-ovarian plexus of all 109 women. For the pelvic blood sample, the visceral peritoneum was opened and after clamping the infundibulopelvic ligament, the utero-ovarian plexus was identified and bisected (6). The outflow was collected in a cup; the procedure was subsequently repeated on the contralateral side. After blood sampling, surgery was completed.

In five patients one ovary was missing because of previous gynaecologic procedures, the contralateral utero-ovarian venous plexus was successfully sampled in all. 


\section{Steroid analysis}

Blood was allowed to clot after collection: the collected serum was stored at $-20^{\circ} \mathrm{C}$ until assayed. In all samples levels were determined of estrone (E1), E2, T, A, SHBG and dehydroepiandrosterone sulphate (DHEAS).

Serum levels of $E_{1}$ and $T$ were measured by radio-immunoassay (RIA) using kits from Diagnostic System Laboratories (Webster, Texas), and an in-house method (Verjans,1973). E2, A and DHEAS were measured with RIA kits (Diagnostic Products Corp., Los Angeles, California). SHBG levels were estimated using a two-site immunoradiometric assay from the same supplier. The sensitivities of the assays and their intra- and interassay variation coefficients were described previously (4).

Free and non-SHBG concentrations of $E_{2}$ and $T$ were calculated using the method described by Sodergard and coworkers (20), and Van den Beld and coworkers (21).

\section{Statistical analysis}

Students' paired T-test was used to estimate statistical differences between hormone levels the peripheral and the utero-ovarian venous samples of the patients. The Mann Whitney U-test was used to estimate differences of steroid levels in patients with and without endometrial cancer. A p-value below 0.05 was considered to reflect statistically significant differences.

\section{Results}

\section{Patient characteristics}

Ninety out of 109 patients were diagnosed as having endometrial cancer. The patients' age in this group varied from 49 to 87 years. The age of patients without endometrial cancer varied from 44 to 77 years. Patients with endometrial cancer were significantly older than patients without (mean age $67.1 \pm 8.8$ versus $58.7 \pm 9.0$ years) $(p=0.001)$. There was no difference in years after menopause between the groups (mean duration $19.1 \pm 7.8$ versus $15.0 \pm 4.2$ years).

Patients with endometrial cancer were significantly more obese than patients without (Body Mass Index $31.3 \pm 2.1$ versus $26.0 \pm 1.8)(p=0.012)$. Six out of 90 patients with endometrial cancer $(7 \%)$ compared to $3 / 19(16 \%)$ without endometrial cancer suffered from hypertension (not significantly different (NS)); 3 out of 90 patients with $(3 \%$ ) versus 1 out of 19 patients without $(5 \%)$ endometrial cancer were current smokers (NS). The mean parity of patients with endometrial cancer was 2.17 , the mean parity of patients without 2.75 (NS).

\section{Steroid levels}

No significant differences were noted between steroid levels in the utero-ovarian veins of either side; for further analyses we used the mean steroid concentration of the two sides. In patients who previously had been hemi-oophorectomized, only steroid concentrations in the blood sample from the remaining side were used for calculations. 
Table 1 Median peripheral and local serum sample concentrations

\begin{tabular}{|c|c|c|c|c|c|}
\hline & & \multicolumn{2}{|c|}{ with endometrial cancer } & \multicolumn{2}{|c|}{ without endometrial cancer } \\
\hline & & Peripheral & Local & Peripheral & Local \\
\hline E2 & $(\mathrm{pmol} / \mathrm{l})$ & 69.5 & 74.5 & 81.0 & 76.0 \\
\hline E1 & $(\mathrm{pmol} / \mathrm{l})$ & 178 & 134 & 158 & 122 \\
\hline $\mathrm{A}$ & $(\mu \mathrm{mol})$ & 1.65 & 11.99 & 1.70 & 11.39 \\
\hline $\mathrm{T}$ & $(\mathrm{nmol} / \mathrm{)})$ & 5.59 & 4.70 & 5.07 & 3.30 \\
\hline DHEAS & $(\mu \mathrm{mol} / \mathrm{l})$ & 3.68 & 3.23 & 2.35 & 3.97 \\
\hline SHBG & $(\mathrm{nmol} / \mathrm{l})$ & 48.8 & 42.6 & 56.4 & 46.0 \\
\hline
\end{tabular}

Table 2 Mean \pm standard error (SEM) of total, free and non-SHBG-bound peripheral and local serum concentrations of $17 \beta$-estradiol $\left(E_{2}, p m o V\right)$ and testosterone (T, nmolv)

*) significantly different from the level in patients with endometrial cancer

\begin{tabular}{|l|c|c|c|c|}
\hline & Peripheral & Local & Peripheral & Local \\
\hline & \multicolumn{2}{|c|}{ with endometrial cancer } & without endometrial cancer \\
\cline { 1 - 1 } Total E2 & $89,9 \pm 12,1$ & $204,3 \pm 63,6$ & $114,8 \pm 32,1$ & $120,5 \pm 34,7$ \\
\cline { 1 - 1 } SHBG & $55,6 \pm 4,3$ & $44,1 \pm 3,2$ & $57,4 \pm 5,7$ & $45,5 \pm 4,5$ \\
\cline { 1 - 1 } Total T & $1,8 \pm 0,1$ & $6,7 \pm 1,2$ & $1,6 \pm 0,1$ & $3,7 \pm 0,4^{*}$ \\
\cline { 1 - 1 } Free E2 & $2,140 \pm 0,3$ & $5,2 \pm 1,6$ & $2,6 \pm 0,7$ & $3,0 \pm 0,9$ \\
\cline { 1 - 1 } NonSHBG-E2 & $57,0 \pm 7,7$ & $138,7 \pm 43,2$ & $70,3 \pm 18,8$ & $80,9 \pm 23,2$ \\
\cline { 1 - 1 } FreeT & $0,03 \pm 0,001$ & $0,1 \pm 0,03$ & $0,03 \pm 0,003$ & $0,07 \pm 0,01^{*}$ \\
\cline { 1 - 1 } NonSHBG-T & $0,82 \pm 0,04$ & $3,7 \pm 0,6$ & $0,724 \pm 0,07$ & $1,9 \pm 0,2^{*}$ \\
& & & & \\
\hline
\end{tabular}

Figure 1 Peripheral and local concentrations of $17 \beta$-estradiol (E2, pmoll) and estrone $\left(E_{1}\right.$, pmolV $)$ in 19 patients without and in 90 patients with endometrial cancer

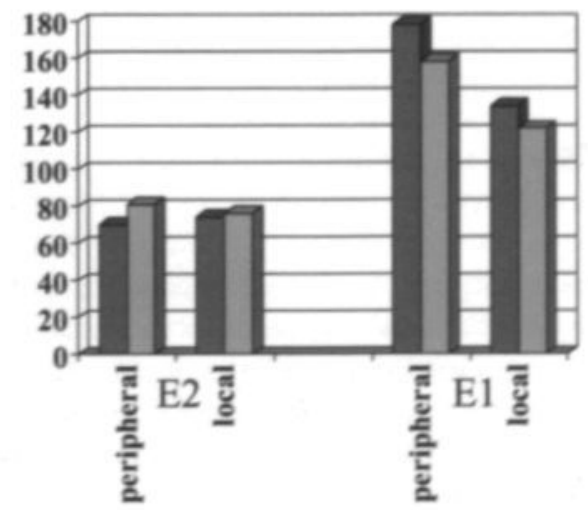


Figure 2 Peripheral and local concentrations of androstenedione (A, nmolVI) and testosterone $(T, n m o l /)$ in 19 patients without and in 90 patients with endometrial cancer

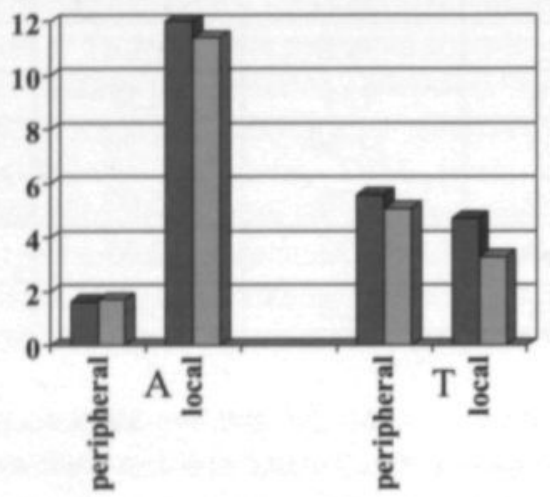

The median peripheral levels in cancer versus non-cancer patients were 69.5 versus $81.0 \mathrm{pmo} / \mathrm{h}$ for $E_{2}$ and 178 versus $158 \mathrm{pmol} / \mathrm{h}$ for $\mathrm{E}_{1}$; the median levels of the uteroovarian vein in cancer versus non-cancer patients were 74.5 versus $76.0 \mathrm{pmol} / \mathrm{l}$ for $\mathrm{E}_{2}$ and 134 versus $122 \mathrm{pmol} / /$ for $E_{1}$ (figure 1). Peripheral and local $E_{2}$ and $E_{1}$ concentrations did not differ significantly between patients with and patients without endometrial cancer. Peripheral concentrations of $E_{1}$ and $E_{2}$ did not differ significantly from local concentrations in patients with or without endometrial cancer.

The median peripheral levels in cancer versus non-cancer patients were 5.59 versus 5.07 $\mu \mathrm{mol} / \mathrm{h}$ for $\mathrm{A}$ and $\mathbf{1 . 6 5}$ versus $1.70 \mathrm{nmo} / \mathrm{h}$ for $\mathrm{T}$. The median levels of the uteroovarian vein in cancer versus non-cancer patients were 11.99 versus $11.39 \mu \mathrm{mo} / \mathrm{h}$ for $A$ and 4.70 versus $3.30 \mathrm{nmol}$ for $\mathrm{T}$ (figure 2). Peripheral and local concentrations of A did not significantly differ between patients with and patients without endometrial cancer, and neither did peripheral concentrations of $\mathrm{T}$. Local concentrations of $\mathrm{T}$ were significantly higher in patients with than in patients without endometrial cancer $(p=0.041)$ (figure 2). Local utero-ovarian vein concentrations of $A$ and $T$ were significantly higher than peripheral concentrations of $A$ and $T(p=0.002$ for $A ; p=0.037$ for T).

The median peripheral levels in cancer versus non-cancer patients were 3.86 versus $2.35 \mu$ molh for DHEAS and 48.8 versus $56.4 \mathrm{nmoh}$ for SHBG. The median levels of the utero-ovarian vein in cancer versus non-cancer patients were 3.23 versus 3.97 $\mu$ molh for DHEAS and 42.6 versus $46.0 \mathrm{nmo} / \mathrm{h}$ for SHBG (figure 3). Peripheral and local concentration differences of DHEAS and SHBG were not statistically significant.

The median peripheral levels of free and non-SHBG-bound $T$ and $E_{2}$ were not significantly different between patients with and patients without endometrial cancer (Table 1). Also, local free and non-SHBG-bound E2 levels were not significantly different between patients with and without endometrial cancer. However, free and non-SHBG-bound T concentrations were significantly higher in patients with than in patients without endometrial cancer. 
Figure 3 Peripheral and local concentrations of dehydroepiandrosterone sulphate (DHEAS, $x$ 10-8 molV and Sex Hormone Binding Globuline (SHBG) (nmoVV in 19 patients without and in 90 patients with endometrial cancer.

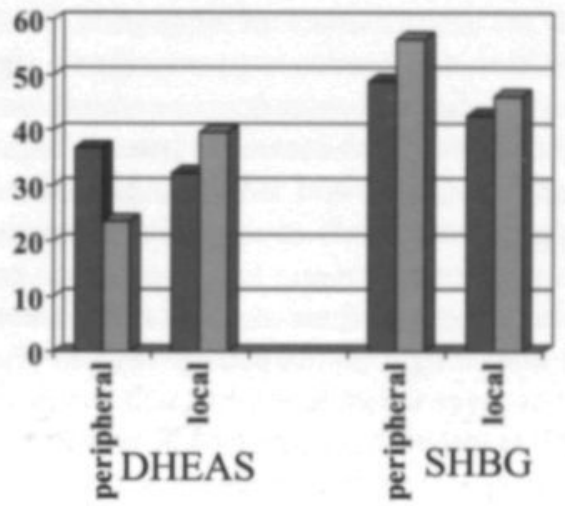

with cancer

without cancer

\section{Discussion}

\section{Postmenopausal steroids}

The ovaries should not be discounted as a source of steroids in postmenopausal women. Most studies of steroid hormone production by postmenopausal ovaries found that $T$ and $A$ are the major steroids produced by postmenopausal ovaries $(3,8$ 11), as also reviewed by Adashi (22).

The present study compared steroid concentrations in peripheral and utero-ovarian veins of postmenopausal patients with or without endometrial cancer. Local uteroovarian vein concentrations of $T$ and $A$ were at least double the peripheral concentrations. These steroids are predominantly produced by stromal tissue derived from theca cells. Mattingly and Huang (14) have shown the ability of postmenopausal ovaries to convert precursors to T, A and dehydroepiandrosterone. Because of the lack of concentration differences for $E_{1}$ and $E_{2}$, we confirm postmenopausal ovaries to be a source of mainly androgens.

Most of the $E_{1}$ in the circulation is derived from peripheral aromatization of A which occurs preferentially in fat and muscle tissue (12-13). Circulating E2 in these women is derived from peripheral conversion of $\mathrm{E}_{1}$ and $\mathrm{T}$.

\section{Androgens and endometrium}

The development of endometrial cancer has been suggested to be influenced by ovarian steroids. These are involved in many regulatory processes in endometrial epithelium, but their role in the development and progression of endometrial cancer is still poorly understood (15-16). Estrogens are associated with cell proliferation, whereas progesterone is associated with cell differentiation. Besides, activities of T might be related to cellular differentiation, whereas its metabolite $5 \alpha$ dihydrotestosterone acts on cellular proliferation (14).

Local estrogen levels were not significantly different between patients with and patients without endometrial cancer, whereas the present study offers evidence of 
high local T and A concentrations; $T$ concentrations were significantly higher in patients with endometrial cancer compared to levels in women without endometrial cancer. Androgens may affect the development of endometrial cancer either directly via interaction with their local tissue receptor, or indirectly via local tissue aromatization into estrogens. Aromatization within the endometrium cells would support the contention of an indirect effect of androgens in the aetiology of endometrial pathology. Yamamoto and coworkers (1) described a significantly higher aromatase activity in endometrial cancer than in normal endometrial cells. This could explain the indirect effect of androgens on endometrial (cancer) cells despite the lack of concentration differences in peripheral and local estrogen blood levels. Little is known about direct growth promoting effects of estrogens (or androgens) on cancer cells (17) via steroid receptors, which are present in normal human endometrium (18). Investigations of steroids and steroid receptor expression in normal and malignant endometrial cells may yield more insight on the pathogenesis of this type of tumor.

\section{References}

1 Yamamoto T, Kitawaki J, Urabe M, Honjo H, Tamura T, Noguchi T, Okada H, Sasaki H, Tada A, Terashima Y, Nakamura J, Yoshihama M. Estrogen productivity of endometrium and endometrial cancer tissue; influence of aromatase on proliferation of endometrial cancer cells. I Steroid Biochem Mol Biol 1993; 44: 463.468

2 Adashi EY. The climacteric ovary as a functional gonadotropin-driven androgenproducing gland. Fertil Steril 1994; 62: 20-27

3 Sluijmer AV, Heineman MJ, de Jong FH, Evers JLH. Endocrine activity of the postmenopausal ovary: the effects of pituitary down-regulation and oophorectomy. J clin Endocrinol Metab 1995; 80: 2163-2167

4 Sluijmer AV, Heineman MJ, Koudstaal Joh, Theunissen PHMH, de Jong FH, Evers JLH. Relationship between ovarian production of estrone, estradiol, testosterone and androstenedione and the ovarian degree of stromal hyperplasia in postmenopausal women. Menopause 1998; 5: 207-210

5 Judd HL, Judd GE, Lucas WE, Yen SSC. Endocrine function of the postmenopausal ovary: concentration of androgens and estrogens in ovarian and peripheral vein blood. I Clin Endocrinol Metab 1974; 39: 1020-1024

6 Heineman MJ, Sluijmer AV, Evers JLH. Utero-ovarian vein blood sampling in postmenopausal women. Fertil Steril 1993; 60: 184-186

7 Kwekkeboom DJ, de Jong FH, Hemert van AM, Vandenbroecke JP, Valkenburg HA, Lamberts SWJ. Serum Gonadotropins and a subunit decline in aging normal postmenopausal women. J Clin Endocrinol Metab 1990; 70: 944-950

8 Lucisano A, Acampora MG, Russo N, Maniccia E, Montemurro A, Dell'Acqua S. Ovarian and peripheral plasma levels of progestagens, androgens and oestrogens in postmenopausal women. Maturitas 1984: 6: 45.53

9 Greenblatt RB, Colle ML, Mahesh VB. Ovarian and adrenal steroid production in the postmenopausal women. Obstet Gynecol 1976; 47: 383-387

10 Longcope C, Hunter R, Franz C. Steroid secretion by the postmenopausal ovary Am J Obstet Gynecol 1980; 138: 564.568 
11 Fujimoto J, Nishigaki M, Hori M, Ichigo S, Itoh T, Tamaya T. Biological implications of estrogen and androgen effect on androgen receptor and its mRNA levels in human uterine endometrium. Gynecol Endocrinol 1995: 9: 149-155 Rizkallah TH, Tovell HMM, Kelly WG. Production of estrone and fractional conversion of circulating androstenedione to estrone in women with endometrial carcinoma. J Clin Endocrinol Metab 1975; 40: 1045-1056

13 Siiteri PK. Postmenopausal estrogen production. In: van Keep PA, Lauritzen C, eds Front Hormone Res (karger, Basel) 1975; 3: 40-45

14 Mattingly RF, Huang WY. Steroidogenesis of the menopausal and postmenopausal ovary. Am J Obstet Gynecol 1969; 103: 679-693

15 Henderson BE, Feigelson HS. Hormonal carcinogenesis. Carcinogenesis 2000; 3: $427-433$

16 Narukawa S, Kanzaki H, Inoue T, Imai K, Higuchi T, Hatayama H, Kariya M, Mori T. Androgens induce prolactin production by human endometrial stromal cells in vitro. J Clin Endocrinol Metab 1994; 1: 165-168

17 Bowan K, Strang P, Backstrom T, Stendahl U. The influence of progesterone and androgens on the growth of endometrial carcinoma. Cancer 1993; 71: 3565-3569

18 Mertens HJMM, Heineman MJ, Theunissen PHMH, de Jong FH, Evers JLH. Androgen, estrogen and progesterone receptor expression during the menstrual cycle Eur J Obstet Gynecol Reprod Biol 2001; 98: 58-65

19 Verjans HL, Cooke BA, de Jong FH, de Jong CM, van der Molen HJ. Evaluation of radioimmunoassay for testosterone estimation. J Steroid Biochem 1973; 4: 665. 676

20 Sodergard R, Backstrom T, Shanbhag V, Carstensen H. Calculation of free and bound fractions of testosterone and $17 \beta$-estradiol to human plasma proteins at body temperature. J Steroid Biochem 1982; 6: 801-810

21 Van den Beld AW, de Jong FH, Grobbee DE, Pols HAP, Lamberts SWJ. Measure of bioavailable serum testosterone and estradiol and their relationships with muscle strength, bone density, and body composition in elderly men. I Clin Endocrinol Metab 2000; 85: 3276-3282

22 Adashi EY. The climateric ovary as a functional gonadotropin-driven androgen producing gland. Fertil Steril 1994; 62: 20-27

23 Jasonni VM, Bonavia M, Lodi S, Preti S, Bulletti C, Flamigni C. Androstenedione metabolism in human uterine tissues: endometrium, myometrium and leiomyoma. J Steroid Biochem; 1982; 17: 547-551 


\title{
CHAPTER 7
}

\section{Steroid receptor content and its heterogeneity in relation to DNA ploidy in benign and malignant endometrium}

\author{
H.J.M.M. Mertens, M.P.G. Leers, M. Nap,
}

N. Kisters, J.E.G.M. Stoot, M.J. Heineman, J.L.H. Evers

(submitted) 


\section{Abstract}

Endometrial hyperplasia, which is supposed to be the reflection of a hyperestrogenic status of endometrium, is considered to be a precancerous disease when complicated with atypia. The histomorphologic subclassification of hyperplasias can not be made in a reproducible manner.

The present study analyzes the contribution of single cell parameters, such as estrogen receptor (ER), progesterone receptor (PR), androgen receptor (AR), S-phase fraction (SPF) and DNA content in normal postmenopausal endometrium versus hyperplastic endometrium and endometrial cancer, using multiparameter flowcytometry (MP-FCM) and immunohistochemistry (IHC) on formalin fixed, paraffin embedded tissue blocks in 57 postmenopausal women. Steroid hormone receptor content and the SPF were not significantly different in hyperplastic endometria with or without atypia. Using IHC, ER and PR showed strong staining, irrespective of the morphologic subclassification, both in epithelial and stromal cells. Using MP-FCM, both ER, PR and AR were strongly elevated in hyperplastic endometrium compared to inactive postmenopausal endometrium but the SPF did not change. With increasing histological grade of the endometrial cancer, ER and PR decreased, whereas AR, the SPF and the percentages of aneuploid tumor cells increased. ER, PR and AR in the diploid tumor fractions were higher than in the aneuploid tumor fractions; the SPF was highest in the aneuploid tumor fraction. No differences could be observed for the parameters mentioned above in either hyperplasia without atypia or hyperplasia with atypia. Our results support the idea that hyperplasia of the endometrium should be considered to be one group in which morphological differences are not sufficiently reproducible. Restrictions for surgical treatment might therefore be redefined. 


\section{Introduction}

Endometrial cancer is the most common cancer of the female genital tract in developed countries; $75 \%$ of all patients with endometrial cancer are postmenopausal (1). Histopathologically, endometrial cancer can be classified as low, intermediate or high grade. Benign endometrium is subdivided into normal, inactive and hyperplastic endometrium that may or may not be accompanied by atypia. Although the first subclassification of endometrial hyperplasias was made in 1949 by Hertig and coworkers (2), there is still considerable controversy in their subclassification. Nowadays, the choice of treatment (medication or surgery) of postmenopausal endometrial patients with endometrial hyperplasia does depend on the morphologic subtype. Atypical hyperplasia of the endometrium is supposed to be a high risk factor or precursor of endometrial adenocarcinoma (3,4). Accurate and sensitive identification of cancer precursors has important clinical value. However, even expert pathologists have problems to classify endometrial hyperplasias in various categories (4-6). Patients with endometrial hyperplasia may for this reason be over- or undertreated.

Endometrial hyperplasias are associated with hyperestrogenic status due to exogenous (for example non-combined hormone replacement therapy) or endogenous (peripheral conversion of androgens in adipose patients) estrogens (3,7). Because hyperplastic endometrium can not always be correctly classified on histologic features alone, we investigated the possible diagnostic contribution of hormone receptorrelated parameters in combination with cell cycle related information. We analysed the contribution of estrogen receptor (ER), progesterone receptor (PR) and androgen receptor (AR) content in normal inactive postmenopausal endometrium, in hyperplastic endometrium, and in malignant epithelial tumors from the endometrium. Roughly three different approaches can be followed to determine the presence or absence of steroid hormone receptors in tumor cells: biochemistry, immunohistochemistry (IHC) or (multiparameter) DNA flowcytometry (MP.FCM). Biochemistry destroys all morphology but gives exact quantities in fmols per gram of protein. IHC preserves morphology but does not allow exact quantification. MP-FCM allows the identification of epithelial cells, which can be marked by the expression of cytokeratins and gives at the same time an objective quantification of the percentage of epithelial cells that is positive for the receptor of interest. Besides, it gives additional information on the DNA content and cell cycle distribution. For this reason, the MP-FCM approach was chosen for the present study.

\section{Materials \& Methods}

\section{Patients' characteristics}

A total of 57 postmenopausal patients underwent an abdominal hysterectomy with salpingo-oophorectomy. There were 22 patients without and 35 patients with endometrial cancer. All patients were more than 12 months after their last menstrual period. None of them used hormone replacement therapy or other steroid hormone medication. There were no pathologic findings in their ovaries. The hospitals' Medical Ethical Committee approved the present study. Patient consent was obtained. 
The patients' age varied from $45-81$ years with a median age of 59 years for patients without endometrial cancer and from 49-87 with a median age of 67 years for patients with endometrial cancer. The median weight of patients without endometrial cancer was $79 \mathrm{~kg}$ (range 60-111), the weight of patients with endometrial cancer was $77 \mathrm{~kg}$ (range 48-123). The body mass index (BMI) of patients without versus patients with endometrial cancer was $27.9 \pm 2.6$ and $30.4 \pm 2.1$, respectively. The ages, weights and BMls were not significantly different between patients with or without endometrial cancer. All endometrial histology was revised by one pathologist (MN). When variations in the level of differentiation of the endometrial cancer was encountered, the tumor was graded according to the most poorly differentiated subpopulation. Of all patients without endometrial cancer, histologic examination showed normal endometrium in 13/22 (59\%); hyperplasia without atypia in $4 / 22$ (18\%); and hyperplasia with atypia in $5 / 22$ (23\%). Of all patients with endometrial cancer the tumor was classified as low grade endometrial cancer (Grade I) in $14 / 35$ ( $41 \%$ ); as intermediate grade endometrial cancer (Grade II) in 13/35 (37\%); and as high grade endometrial cancer (Grade III) in $8 / 35$ (23\%); 3 of these were papillary serous cancers.

\section{Preparation of cell suspension}

For the preparation of the single cell suspension, the technique described in a previous report was used. Briefly, for every assay two $50 \mu \mathrm{m}$ thick sections were cut from each paraffin block and put in a glass tube. Subsequently, these tissue sections were deparaffinized twice in xylene, 30 minutes each, and then rehydrated in a descending ethanol series. Sections were rinsed in phosphate buffered saline (PBS; $\mathrm{pH} 7.2 \cdot 7.4$ ). The sections were immersed with cold citrate solution ( $2 \mathrm{mg}$ citric acid/ml aqua dest; $\mathrm{pH}=6.0$ ), and subjected to a 120 minute heating step in an $80^{\circ} \mathrm{C}$ water bath. After a short cooling down period, a freshly prepared solution of $1 \mathrm{mg} / \mathrm{ml}$ pepsin (Sigma, St. Louis, MO, USA) in $0.1 \mathrm{~N} \mathrm{HCl}$ was added at room temperature and allowed to digest for a maximum of 10 minutes at $37^{\circ} \mathrm{C}$. A single cell suspension was obtained by vortexing and filtration of the sample through a $50 \mu \mathrm{m}$ mesh nylon filter. The cell suspension was then centrifuged at $400 \mathrm{~g}$ and the cell pellet was resuspended in 500 $\mu$ PBS, supplemented with $1 \%$ bovine serum albumin (BSA/PBS buffer; Sigma).

\section{Multiparameter Flow Cytometry (MP-FCM)}

The single cell suspension was aliquoted into $100 \mu \mathrm{l}$ samples (approximately 106 cells per $100 \mu$ PBS). To each sample both properly diluted monoclonal and polyclonal antibodies were added simultaneously: the epithelial cells were identified using polyclonal pan-cytokeratin, (Zo622, DAKO A/S, Glostrup, Denmark, 1:500), next to a monoclonal antibody against the receptor of interest (1D5 for ER, 1:33; and PgR636 for PR, 1:33, both from DAKO; and F39.4 for AR, 1:33. Biogenex, San Ramon, CA, USA). A double PBS rinsing step followed an overnight incubation at room temperature. The reaction of the primary antibodies was visualized by incubating the cell pellet simultaneously with the secondary antibodies, i.e. goat-anti-mouse-lg-FITC (DAKO, 1:10) for the monoclonal antibody, and goat-anti-rabbit-lg-RPE for the polyclonal antibody (Southern Biotechnology Association, Inc, Birmingham, Alabama, USA; 1:12) for $11 / 2$ hours at room temperature. The samples were rinsed in PBS two times and finally DNA was stained using propidium iodide (PI, $1.0 \mu \mathrm{g} / \mathrm{ml}$, Sigma) in PBS containing $0.1 \mathrm{mg} / \mathrm{ml}$ RNAse (Sigma). The samples were allowed to stand for minimal 
1 hour in the dark at $4^{\circ} \mathrm{C}$ before flow cytometric analysis. As a negative control for background staining by the primary antibody, a portion of the cell suspension was incubated with a non-relevant mouse immunoglobulin (Xo931, DAKO, 1:33) or a nonrelevant rabbit immunoglobulin (Xo903, DAKO, 1:300).

\section{Flow cytometric analysis}

Samples were analyzed using a DAKO Galaxy flow cytometer (provided for this study by DAKO). Cells were excited with a single $488 \mathrm{~nm}$ air-cooled Argon ion laser. FITC. fluorescence was detected through a $520 \mathrm{~nm}$ BP filter, RPE-fluorescence through a 590 $\mathrm{nm}$ BP filter and PI-fluorescence through a $630 \mathrm{~nm}$ LP filter. At least 20,000 relevant events were collected for each sample. FITC- and RPE-signals were recorded as logarithmic amplified data, while the PI-signals were recorded as linear amplified data. The following settings were used: $512 \mathrm{~V}, 360 \mathrm{~V}$ and $438 \mathrm{~V}$ on photomultiplier tubes for $\mathrm{FL}_{1}$ (FITC), FL2 (RPE) and $\mathrm{FL}_{3}(\mathrm{PI})$, respectively. A software-based compensation was performed afterwards using the Flomax Software (Partec GmbH, Munster, Germany). Cell cycle analysis was performed using Modfit LT 2.0 (Verity Software House Inc, Topsham, Maine, USA). The following data were collected:

(1) Ploidy, DNA-index and SPF of the total, and different cytokeratin positive cell populations.

(2) The percentage of ER-, PR-, and AR- positive cells in the total epithelial compartment.

(3) If aneuploid cell were encountered, these data were collected separately for diploid and aneuploid fractions.

The number of positive cells was determined in the cell suspension by an arbitrary threshold setting allowing not more than $5 \%$ positive counts in the negative control. The data were analyzed statistically using the Mann Whitney U-test. Also the independent sample t-test was used whenever appropriate. A p-value of less than 0.05 was considered to reflect statistically significant differences.

\section{Immunohistochemistry (IHC)}

Steroid receptor IHC was performed for ER and PR on $3 \mu \mathrm{m}$ thick paraffin sections. These sections were de-waxed, rehydrated and immersed for 10 minutes in methanol with $0,3 \% \mathrm{H}_{2} \mathrm{O}_{2}$ to block endogenous peroxidase activity. After rinsing in tap water, the sections were immersed in $0.01 \mathrm{M}$ sodium citrate solution $(\mathrm{pH} \mathrm{6.0)}$ in a microwave-resistant container, and were then heated for 10 minutes at 700 Watts $(t$ $90^{\circ} \mathrm{C}$. After cooling to room temperature the sections were rinsed in phosphatebuffered saline (PBS, pH 7.2-7.4). All sections were then pre-incubated with $1 \%$ bovine serum albumin in PBS for 15 minutes. The hormone receptors were detected using anti-ER (1D5, DAKO) and anti-PR (PgR636, DAKO) at a dilution of 1:100 both. The sections were incubated with the antibodies overnight at room temperature.

After rinsing in PBS, sections were incubated with biotinylated goat-anti-mouse-Ig (LSAB2-kit, DAKO) for 30 minutes at room temperature. After rinsing with PBS, the sections were incubated with peroxidase labeled streptavidin (LSAB2-Kit, DAKO) for 30 minutes at room temperature.

Antibody binding was visualised by incubating the sections with $\mathrm{DAB} / \mathrm{H}_{2} \mathrm{O}_{2}$-solution (3'3-diamidinobenzidine, DAB-liquid substrate, DAKO) for 7 minutes at room temperature in the dark. Nuclear counterstaining was performed in hematoxylin (1 
minute) and rinsing in tap water. Finally, slides were embedded with aid of an automatic coverslipper (TissueTek, Takahara). Intensity of ER and PR staining were scored visually semiquantitatively in epithelial (tumor) cells. Receptor reactivity was scored in three different classes: clearly positive receptor staining was separated from absence of staining or low receptor staining.

\section{Statistical analysis}

Values of steroid hormone receptor content are expressed in (mean) percentages of positive epithelial cells (mean \pm standard deviation). The Mann Whitney U-test was used to determine statistically significant differences between two groups. A p-value less than 0.05 was considered to reflect statistically significant difference.

\section{Results}

$E R, P R$ and $A R$ content analyzed using multiparameter flowcytometry are shown in figure 1, 2 and 3 respectively. Overall, ER and PR content were not significantly different between patients with and patients without endometrial cancer (52.9 \pm 13.2 versus $43.9 \pm 20.3$ for ER and $55.0 \pm 18.5$ versus $44.1 \pm 18.4$ for PR). AR content was higher in patients with endometrial cancer when compared with patients without endometrial cancer (35.6 \pm 10.8 versus $17.7 \pm 10.5$, prooo1). The SPF was different between patients with as compared with patients without endometrial cancer ( $8.4 \pm$ 6.2 versus $6.0 \pm 3.0)(p=0.43)$ (figure 4$)$. IHC showed strong staining for ER and PR in all specimens, irrespective of the histomorphologic subtype. Of all samples $95 \%$ showed positive nuclear receptor staining for ER; $78 \%$ showed positive receptor staining for PR. Positive staining in epithelial cells was accompanied by positive staining in stromal and myometrial cells. Vascular endothelium remained negative.

The comparison from MP.FCM with IHC in the present study showed few agreements. Whereas MP.FCM analyses were performed in restricted epithelial populations, based on immunological phenotypes, IHC has the entire section for evaluation. The overwhelming effect of the presence of receptors both in stroma, myometrium and epithelium makes it hard to perform a reliable semiquantitative analysis.

\section{Benign inactive postmenopausal endometrium}

$E R$ and PR in postmenopausal inactive endometria were found to be relatively low. ER content was $29.7 \pm 21.3$; PR content was $25.2 \pm 17.3$; and AR content was $11.6 \pm$ 6.6. The SPF in normal endometrium was $6.2 \pm 3.3$. All benign postmenopausal endometrium samples had a diploid DNA content (figure 5).

\section{Endometrial hyperplasia}

Steroid hormone receptor content in endometrial hyperplasia without atypia was 61.7 \pm 9.1 for ER; $63.7 \pm 6.6$ for PR; and $24.6 \pm 12.1$ for AR. DNA indices were diploid and the SPF in endometrial hyperplasia without atypia was $5.3 \pm 0.8$. The steroid hormone receptor content in hyperplastic endometrium with atypia was $45.6 \pm 12.5$ for ER; 51.7 \pm 8.6 for PR; and $30.2 \pm 11.7$ for AR. The SPF in hyperplastic endometrium with atypia was $8.9 \pm 2.2$. 
There were no differences in ER, PR, AR content and in the SPF between endometrial hyperplasia without versus endometrial hyperplasia with atypia. Irrespective of the presence of atypia, in endometrial hyperplasias $(n=9)$ ER content was $56.9 \pm 11.4$ : PR content was $55.5 \pm 9.5$ : AR content was $24.4 \pm 11.1$. The S-phase fraction in hyperplastic endometrium was $6.9 \pm 2.4$.

\section{Endometrial adenocarcinoma}

ER content in Grade I endometrial adenocarcinomas was $59.8 \pm 6.2$; PR content was $68.8 \pm 7.5$ : AR content was $31.0 \pm 9.2$. In Grade II endometrial adenocarcinomas steroid hormone receptor content was $47.1 \pm 7.5$ for ER; $44.9 \pm 9.9$ for PR and 37.4 \pm 10.6 for AR. In high Grade endometrial carcinomas ER content was $32.6 \pm 12.6$; PR content was $29.2 \pm 24.5$; AR content was $43.8 \pm 10.0$. The S-phase fractions in Grade I; II and III endometrial adenocarcinomas were $6.8 \pm 3.3 ; 9.2 \pm 4.2$ and $15.1 \pm 7.7$ respectively.
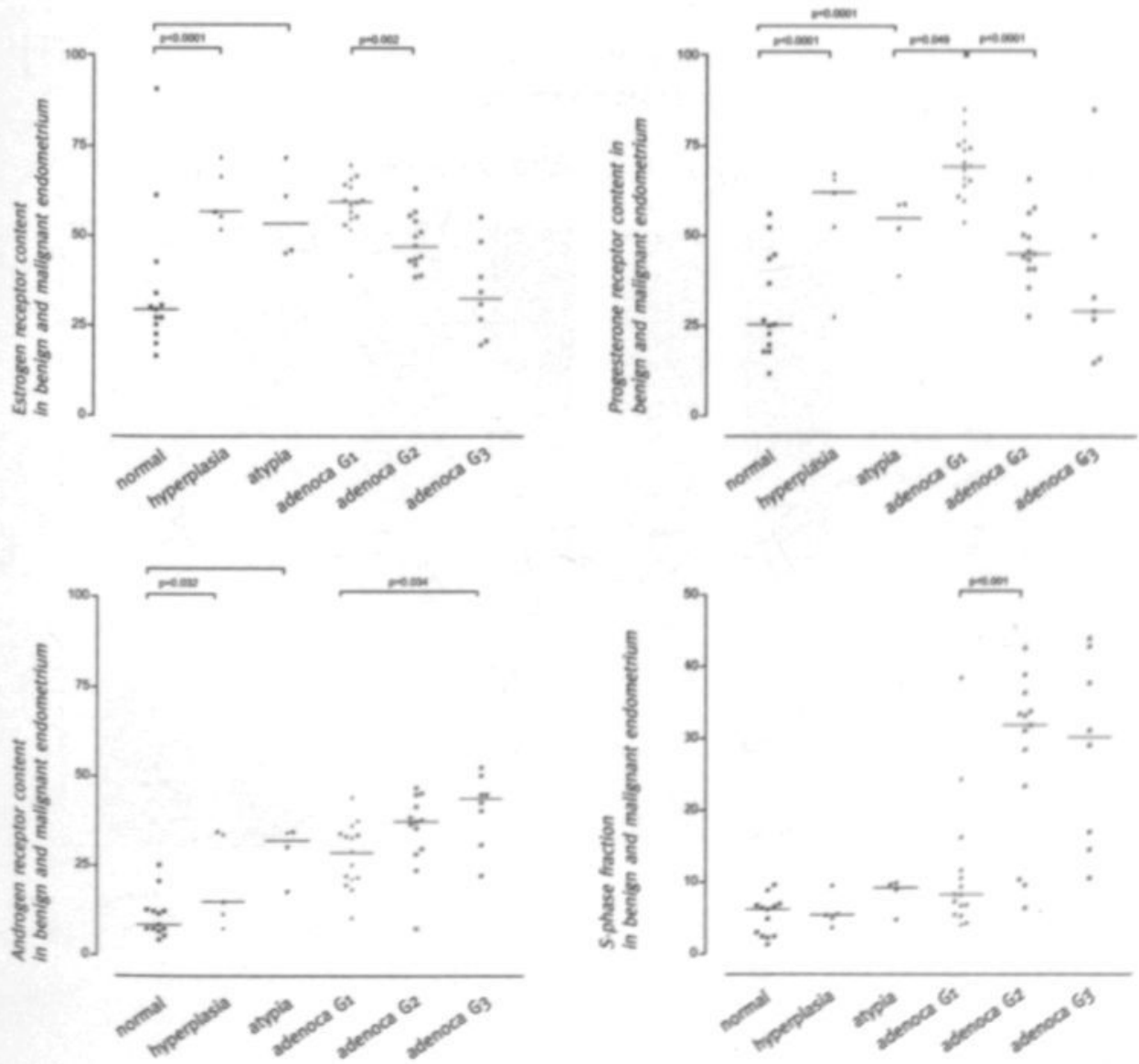


\section{Heterogeneity of steroid receptor content in relation to DNA ploidy}

In the group of Grade I endometrial cancers 12/14 (86\%) tumors were diploid (figure 5). One non-diploid tumor showed a tetraploid DNA-profile; one showed a DNA index of 1.20 . Of all Grade II tumors $3 / 13$ (23\%) were diploid; three out of 10 non-diploid Grade II tumors were tetraploid. The DNA index of the remaining aneuploid tumors varied from 1.20 to 2.20 . Of all Grade III endometrial cancers $2 / 8(25 \%)$ were diploid and 2/8 were tetraploid. The DNA index of the aneuploid tumors varied from 1.26 to 2.16. The percentages of aneuploidy in Grade II and III cancers were significantly higher than in Grade I tumors (both pro.0001). Besides, the percentages of tetraploidy amongst the tumors were significantly different between Grade I versus Grade II and Grade I versus Grade III tumors (both pro.oo1).

In this study it became apparant that when a tumor was aneuploid, in all cases also a diploid epithelial tumor cell population could be detected. When aneuploid, ER, PR and AR were analyzed in the different tumor cell compartments (diploid versus aneuploid). Results are shown in Table 1. ER content of Grade I tumors was not significantly different between the diploid and the aneuploid fraction (59.8 \pm 9.1 versus $57.6 \pm 7.7)$. ER content in the diploid fractions of Grade II and Grade III tumors were higher than the ER content in the aneuploid fraction (64.8 \pm 17.6 versus $32.2 \pm$ 10.8 ( $p=0.042$ ) for Grade II; and $51.8 \pm 9.7$ versus $20.3 \pm 9.3$ (pro.001) for Grade III tumors).

Figure 5 DNA ploidy of endometrium samples

\section{Ploidy type}

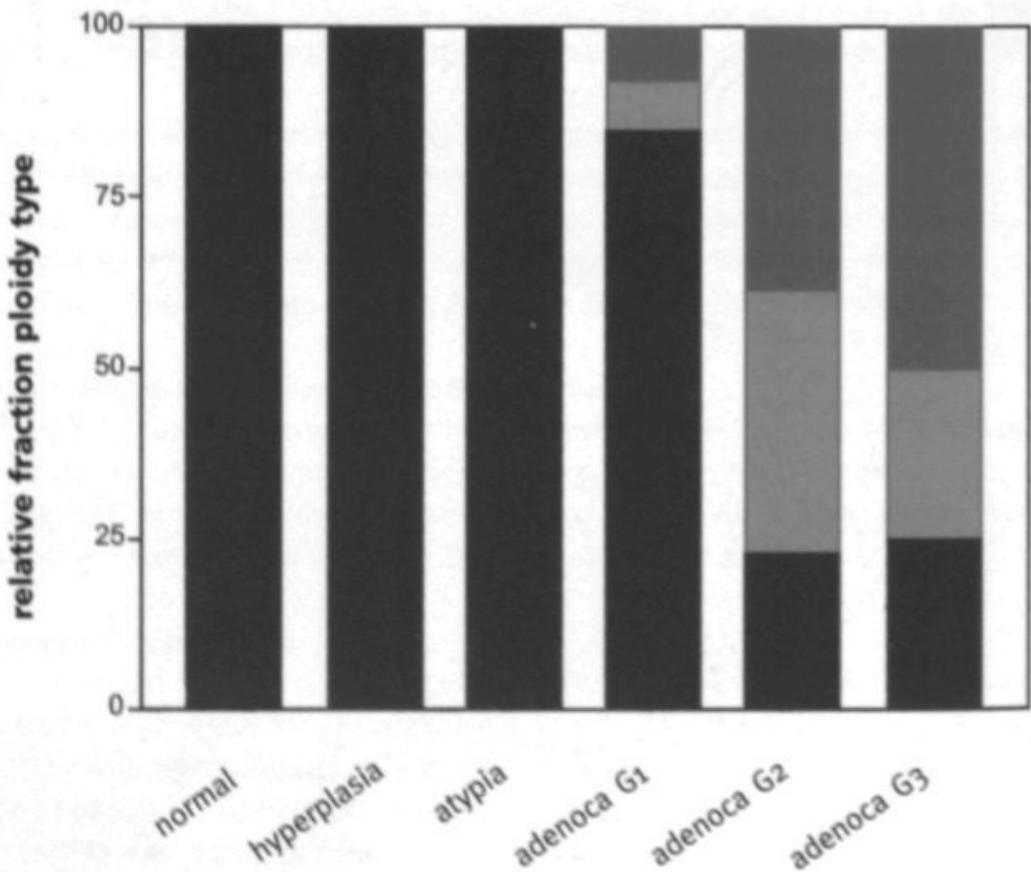


In the diploid fraction of Grade I tumors, PR content was not significantly different as compared with the aneuploid fraction (68.8 \pm 8.9 versus $56.3 \pm 4.7)$. PR content in the diploid fractions of Grade II and Grade III tumors was higher than PR content in non-diploid fractions $(73.0 \pm 19.1$ versus $34.4 \pm 10.7 \quad(p=0.01)$ for Grade II and $55.3 \pm$ 12.7 versus $17.7 \pm 11.0(p=0.03)$ for Grade III).

Endometrial cancer cells contain less AR than ER and PR. AR content in the diploid fractions of Grade I tumors was not significantly different from AR content in the aneuploid fractions $(33.2 \pm 11.3$ versus $24.4 \pm 23.2$ ). The AR content in diploid tumor fractions in Grade II and Grade III were higher than AR content in the aneuploid tumor fraction (58.2 \pm 21.5 versus $25.5 \pm 6.8$ for Grade II and $54.6 \pm 20.1$ versus $34.5 \pm 9.7$ for Grade III, both pro.001). Besides, in the diploid tumor fraction AR content in Grade II and Grade III tumors was higher than in Grade I tumors.

The S-phase fractions were significantly lower in the diploid fraction when compared to the aneuploid tumor fractions in the group of Grade I, Grade II and Grade III endometrial cancers. S-phase fraction in diploid versus aneuploid fractions were 7.3 \pm 3.7 versus $31.4 \pm 10.0$ for Grade I; $9.6 \pm 4.7$ versus $33.3 \pm 5.4$ for Grade II and 12.4 \pm 6.2 versus $34.5 \pm 10.1$ for Grade III endometrial tumors (for all three, pro.0001). There were no significant differences between the S-phase fractions of the diploid or aneuploid tumor fraction in respective to the grade of tumor.

Table 1 Steroid Receptor content and S-phase fractions in diploid and aneuploid tumor fractions

Steroid receptor heterogeneity and S-phase fractions (SPF) in endometrial cancer. Estrogen receptor (ER), progesterone receptor (PR), androgen receptor (AR) expression and S-phase fractions (S-phase) are shown in diploid (d) and non-diploid (a) tumor fractions. Differences in expression between both tumor fractions (rows) as well as differences in respective of the Grade of tumor (columns) are shown: corresponding letters mean non-significant differences; different letters mean significant differences.

\begin{tabular}{|l|c|c|c|c|c|c|}
\hline & ERd & ERa & PRd & PRa & ARd & ARa \\
\hline Grade I & $\begin{array}{c}59.8 \pm 9.1 \\
\text { ad }\end{array}$ & $\begin{array}{c}57.6 \pm 7.7 \\
\text { ad }\end{array}$ & $\begin{array}{c}68.8 \pm 8.9 \\
\text { a }\end{array}$ & $\begin{array}{c}56.3 \pm 4.7 \\
\text { a }\end{array}$ & $\begin{array}{c}33.2 \pm 11.3 \\
\text { a }\end{array}$ & $\begin{array}{c}24.4 \pm 23.2 \\
\text { a }\end{array}$ \\
\hline Grade II & $\begin{array}{c}64.8 \pm 17.6 \\
\text { ab }\end{array}$ & $\begin{array}{c}32.2 \pm 10.8 \\
\text { c }\end{array}$ & $\begin{array}{c}73.0 \pm 19.1 \\
\text { a }\end{array}$ & $\begin{array}{c}34.4 \pm 10.7 \\
\text { b }\end{array}$ & $\begin{array}{c}58.2 \pm 21.5 \\
\text { b }\end{array}$ & $\begin{array}{c}25.5 \pm 6.8 \\
\text { a }\end{array}$ \\
\hline Grade III & $\begin{array}{c}51.8 \pm 9.7 \\
\text { d }\end{array}$ & $\begin{array}{c}20.3 \pm 9.3 \\
\text { ce }\end{array}$ & $\begin{array}{c}55.3 \pm 12.7 \\
\text { a }\end{array}$ & $\begin{array}{c}17.7 \pm 11.0 \\
\text { c }\end{array}$ & $\begin{array}{c}54.6 \pm 20.1 \\
\text { b }\end{array}$ & $\begin{array}{c}34.5 \pm 9.7 \\
\text { a }\end{array}$ \\
\hline
\end{tabular}

\begin{tabular}{|l|c|c|}
\hline & SPFd & SPFa \\
\hline Grade I & $\begin{array}{c}7.3 \pm 3.7 \\
\text { a }\end{array}$ & $\begin{array}{c}31.4 \pm 10.0 \\
\text { b }\end{array}$ \\
\hline Grade II & $\begin{array}{c}9.6 \pm 4.7 \\
\text { a }\end{array}$ & $\begin{array}{c}33.3 \pm 5.4 \\
\text { b }\end{array}$ \\
\hline Grade III & $\begin{array}{c}12.4 \pm 6.2 \\
\text { a }\end{array}$ & $\begin{array}{c}34.5 \pm 10.1 \\
\text { b }\end{array}$ \\
\hline
\end{tabular}




\section{Steroid hormone receptor content in relation to histomorphology}

$E R, P R$ and AR content were higher in hyperplastic endometrium than in normal, age related inactive endometrium ( $p<0.0001$ for $E R$ and $P R ; p=0.027$ for $A R$ ), whereas the S-phase fraction did not differ. Steroid hormone receptor content was higher in Grade I endometrial cancer versus endometrial hyperplasia $(p=0.049$ for PR; NS for ER and AR). With the increase of the grade of tumor, the SPF and AR content increased whereas ER and PR decreased. The p-values are shown in figure 1-4. In figure 6 and figure 7 the ER and AR content is illustrated in relation to the SPF.

Figure 6 Estrogen receptor content in relation to S-phase fraction of benign and malignant endometrium

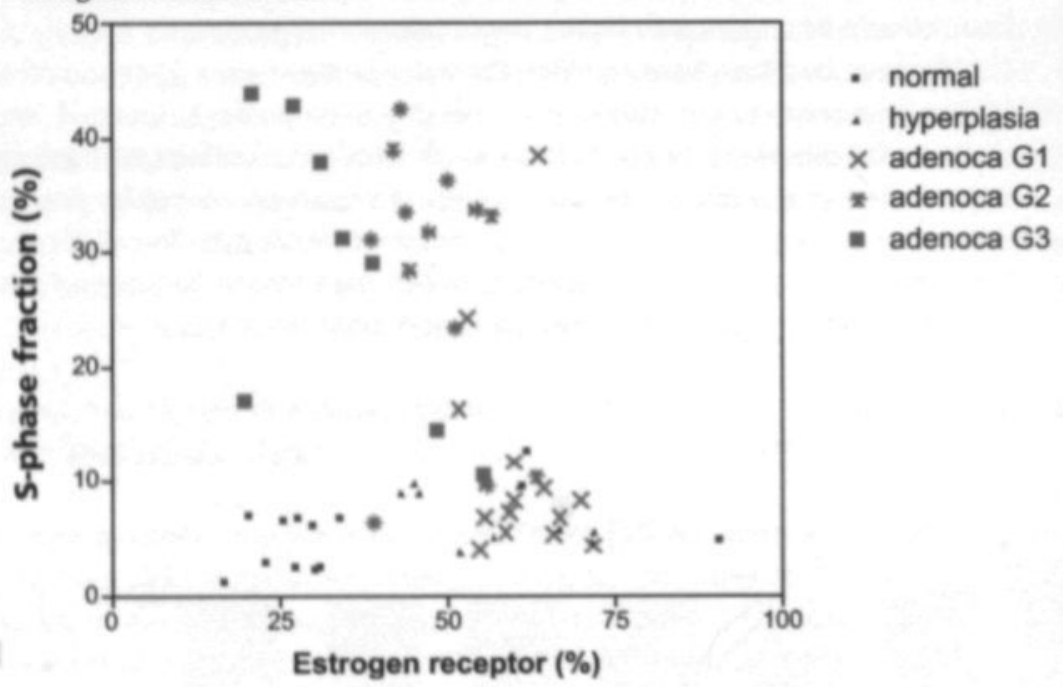

Figure 7 Androgen receptor content in relation to S-phase fraction of benign and malignant endometrium

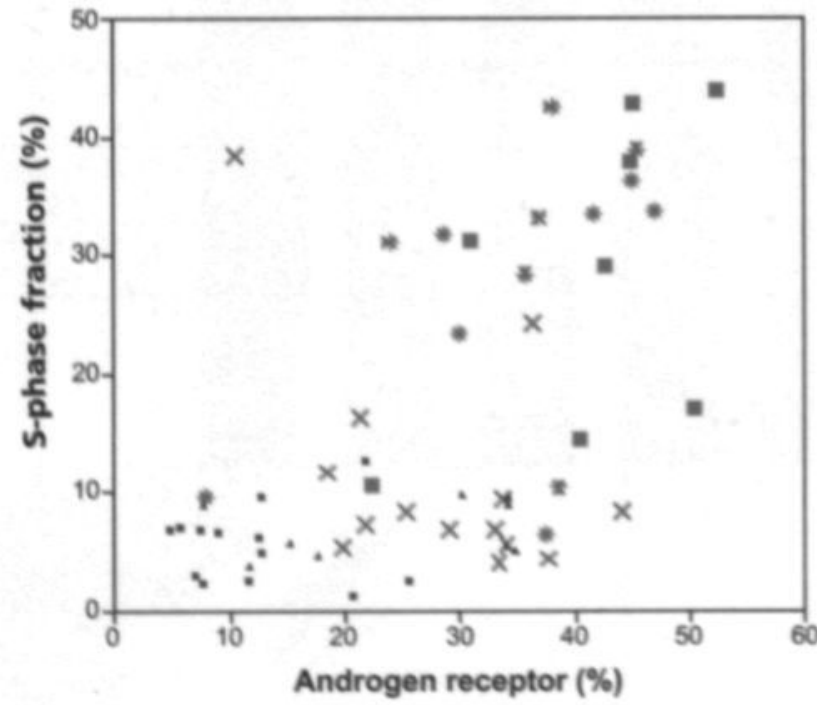

- normal

- hyperplasia

$\times$ adenoca $\mathrm{G1}$

- adenoca G2

- adenoca G3 


\section{Discussion}

Endometrial hyperplasia with or without atypia is considered to belong to a process with increased risk for the development of endometrial cancer. In case there is hyperplasia with atypia, surgery is the treatment of choice and in case there is hyperplasia without atypia, patients will be treated with progesterone. The evidence for the present treatment strategy is obtained from several studies, showing that patients with atypical complex endometrial hyperplasia have a greater risk of progression than patients with endometrial hyperplasia without atypical characteristics (8-11). From the work of Bergeron and coworkers, it became evident that even expert pathologists have trouble to reach consensus on subclassification of the type of hyperplasia. From observations in a population of only 56 patients judged by a group of five expert gynecologic pathologists, they concluded that the histological classification must be simplified. The morphologic endometrial features, giving rise to confusion in the study of Bergeron and coworkers, were simple and atypical hyperplasia and well differentiated endometrial carcinoma (5). For this reason, diagnostic efforts are directed to identify patients within the hyperplasia category correctly, which have increased risks for endometrial cancer.

In relation to this diagnostic dilemma, the results obtained in the present study show various interesting aspects, although the absolute numbers in the present study are not very large.

Multiparameter flowcytometry showed that the three subgroups mentioned above, do not differ in steroid hormone receptor content, SPF and DNA ploidy. Hyperplasia of the endometrium, which is supposed to be a reflection of an estrogenic effect on endometrium (12), could be separated from normal postmenopausal endometrium by a significant increase in the levels of ER and PR positive cells. Proliferation, as expressed by the SPF of the epithelial cells, was not increased in the hyperplastic endometria as compared to normal inactive endometria. A change in proliferative activity as indicated by the S-phase fraction was first seen in Grade II and Grade III endometrial adenocarcinomas. Apparently, the hyperplastic status of the endometrium is not synonymous with increased proliferation but seems to be associated with prolonged survival.

This is also supported by the findings of Morsi and coworkers who found that the levels of Bcl-2 expression, an inhibitor of apoptosis, in hyperplastic endometrium are significantly increased (13). Despite this form of correlation, little is known about the sequential meaning of the increased expression of ER and Bcl-2 in endometrial hyperplasia. If there is a causal relation, this could be by initial overexpression of ER followed by inhibition of apoptosis as a result of increased Bcl-2 expression or the other way around. The fact that endometrial hyperplasia as well as endometrial cancer are predominantly disorders of postmenopausal women doubts whether the loss of cyclic hormonal changes plays a role in the initial step of the stabilization of ER expression in a subpopulation with later increase of both ER and Bcl-2. A finding that is in favor of the idea of hormonal dysregulation in the development of a hyperplastic state, is the coincidental elevation of both ER and PR as well as AR, a combination that is normally not found in cyclic endometrium. Although we have found also an increased AR expression in both hyperplasia and cancer, information from the literature about the role of the AR is not extensive. In normal cyclic endometrium, AR 
is significantly higher in proliferative than in the secretory phases $(14,15)$. Besides, serum concentrations of androstenedione and testosterone in the pelvic veins were also increased in patients with endometrial hyperplasia (unpublished data).

These values are even higher in patients with endometrial cancer (16). By in situ hybridization and immunocytochemistry was shown that AR expression is increased by estradiol stimulation, whereas estradiol with progesterone stimulation decreased AR expression (17). Could it be that there is a regulatory disturbance at this level that makes the endometrium become hyperplastic and if there is no intervention, progress to carcinoma? A better understanding of the endometrial carcinogenesis and of cancer precursors may give rise to potential development of (endocrine) therapy.

Some studies report on the interaction between regulatory proteins of proliferation and apoptosis, such as p53 and PTEN by altered hormonal status in the carcinogenesis of several epithelial tumors (18-21). Molecular pathologic studies in endometrial hyperplasias and endometrial adenocarcinomas showed mutations in PTEN and K-ras suppressor gene mutations $(4,19-23)$. Loss of the PTEN function for example, means an early event in endometrial carcinogenesis. $\mathrm{P}_{53}$ is not expressed in endometrial hyperplasia, but is expressed in endometrial adenocarcinomas. Two pathways are described on endometrial carcinogenesis.

One accompanied or precursed by endometrial hyperplasia due to the estrogenic proliferative stimuli on the endometrium; the other pathway due to PTEN and K-ras mutations with absence of endometrial hyperplasia. Whether both pathways act on each own or may influence each other is not clarified yet.

The presence of DNA aneuploidy in endometrial cancer is associated with poorer survival $(8,24,25)$. In the present study, $24 \%$ of aneuploid tumors were tetraploid. It has been suggested that tetraploidy is an intermediate stage due to a spontaneous tendency of diploid tumor cells to double their DNA content as a failure of cytokinesis or cell fusion: real aneuploidy of tumor cells is due to loss of chromosomes during replication $(26,27)$. The loss of ER in intermediate and high Grade carcinomas was also seen in breast cancer (28).

Both in studies using single DNA ploidy measurements as well as in MP.FCM assays, this phenomenon was seen and because of the selection of epithelial cells before detailed analysis, it became clear that most tumors contain fractions of diploid tumor cells that have retained their receptor profile.

In respect to the present findings, we would recommend to reconsider the present treatment strategies for endometrial hyperplasia. In view of the fact that correct histological classification is hard to obtain and the MP.FCM approach of ER and PR determination in combination with SPF gives a broader basis under the classification of hyperplasia versus non-hyperplasia, we would like to suggest progesterone withdrawal therapy as an initial step for all patients with endometrial hyperplasia. Patients who do not respond are perhaps more likely to have, or progress to well differentiated endometrial cancer or may be at higher risk for development of endometrial cancer. They could be offered a hysterectomy as a second step. Ultrasound measurements of the endometrial thickness, before and after progesterone therapy as is done regularly, will select the non-responders. In this way, a more evidence based treatment approach and indication for hysterectomy might be created. 


\section{References}

1 Visser 0, Coebergh JWW, Schouten LJ, van Dijck JAAM. Incidence of cancer in the Netherlands 1997. Netherlands Cancer Registry, VIKC 2001

2 Hertig AT, Sommers SC, Bengloff H. Genesis of endometrial cancer. A study of prior biopsies. Cancer 1949; 2: 946-956

3 Inoue $M$. Current molecular aspects of the carcinogenesis of the uterine endometrium. Int J Gynecol Cancer 2001; 11: 339-348

4 Mutter GL. Diagnosis of premalignant endometrial disease. J Clin Pathol 2002; 55: 326-331

5 Bergeron C, Nogales FF, Masseroli M, Abeler V, Duvillard P, Muller-Holzner E, Pickartz $\mathrm{H}$, Wells $\mathrm{M}$. A multicentric European study testing reproducibility of the WHO classification of endometrial hyperplasia with a proposal of a simplified working classification for biopsy and curettage specimens. Am I Surg Pathol 1999: 23: 1102-1108

6 Mutter GL, Baak JPA, Crum CP, Richart RM, Ferenczy A, Faquin WC. A multidisciplinary approach to diagnosis of endometrial precancers: clonal analysis, histopathology, and computerized morphometry. Am J Pathol 2000; 190: 462-469

7 Cavanagh D, Marsden DE, Ruffolo EH. Carcinoma of the endometrium. Obstet Gynecol Annu 1984; 13: 211-260

8 Baak JPK, Wisse-Brekelmans ECM, Fleege JC, van der Putten HW, Bezemer PD. Assessment of risk on endometrial cancer in hyperplasia, by means of morphological and morphometrical features. Pathol Res Pract 1992; 188: 856-859

9 Huang SJ, Amparo EG, Fu YS. Endometrial hyperplasia: Histologic classification and behavior, Surg Pathol 1988; $1: 215-229$ Kurman RJ, Kaminski PF, Norris HJ. The behavior of endometrial hyperplasia: a long-term study of 'untreated' hyperplasia in 170 patients. Cancer 1985; 56: 403 412

11 Sherman Al, Brown S. The pre-cursors of endometrial carcinoma. Am J Obstet Gynecol 1979; 135: 947-956

12 Speroff L, Glass RH, Kase NG. Clinical Gynecologic Endocrinology and Infertility, $5^{\text {th }}$ ed. Williams and Wilkins 1994

13 Morris HM, Leers MP, Radespiel-Troger M, Bjorklund V, Kabarity HE, Nap M, Jager W. Apoptosis, Bcl-2 expression, and proliferation in benign and malignant endometrial epithelium: an approach using multiparameter flow cytometry. Gynecol Oncol 2000; 77: 11-17

14 Mertens HJMM, Heineman MJ, Theunissen PHMH, de Jong FH, Evers JLH. Androgen, estrogen and progesterone receptor expression in the human uterus during the menstrual cycle. Eur J Obstet Gynecol and Reprod Biol 2001; 98: 58-65.

15 Horie K, Takakura K, Imai K, Liao S, Mori T. Immunohistochemical localization of androgen receptor in the human endometrium, decidua, placenta and pathologic conditions of the endometrium. Hum Reprod 1992; 7: 1461-1466

16 Mertens HJMM, Heineman MJ, de Jong FH, Evers JLH. Steroids in postmenopausal women with and without endometrial cancer (submitted).

17 Slayden OD, Nayak NR, Burton KA, Chwalisz K, Cameron ST, Critchley HO, Baird DT, Brenner RM. Progesterone antagonists increase androgen receptor expression in the rhesus macaque and human endometrium. I Clin Endocrinol 
Metab 2001; 86: 2668-2679

18 Henderson BE, Feigelson HS. Hormonal carcinogenesis. Carcinogenesis 2000; 21: 427-433

19 Kaku T, Kamura T, Hirakawa T, Sakai K, Ameda S, Kobayashi H, Nakano H. Endometrial carcinoma associated with hyperplasia-immunohistochemical study of angiogenesis and p53 expression. Gynecol Oncol 1999; 72: 51-55

20 Matias-Guiu X, Catasus L, Bussaglia E, Lagarda H, Garcia A, Pons C, Munoz J, Arguelles R, Machin P, Prat J. Molecular pathology of endometrial hyperplasia and carcinoma. Hum Pathol 2001; 32: 569-577

21 Ruhul Quddus M, Latkovich P, Castellani WJ, James Sung C, Steinhoff MM, Briggs RC, Miranda RN. Expression of cyclic D1 in normal, metaplastic, hyperplastic endometrium and endometrioid carcinoma suggests a role in endometrial carcinogenesis. Arch Pathol Lab Med 2002; 126: 459-463

22 Terlikowski S, Lenczewski A, Famulski W, Sulkowska M, Dobrzycka B, StasiukBarmuta A, Kulikowski M. Patterns of immunohistochemical staining for p53 expression in hyperplastic endometrium and adenocarcinoma. Folia Histochem Cytobiol 2001; 39: 195-196

23 Teleman S, Mihailovici MS, Hilgarth M, Freudenberg N, Bettendorf H. P53 and steroid receptors support double endometrial carcinogenesis (abstract). Rev Med Chir Soc Med Nat lasi 1999; 103: 131-135

24 Larson DM, Berg R, Shaw G, Krawisz BR. Prognostic significance of DNA ploidy in endometrial cancer. Gynecol Oncol 1999; 74: 356-360

25 Jhala DN, Atkinson BF, Balsara GR, Hernandez E, Jhala NC. Role of DNA ploidy analysis in endometrial adenocarcinoma. Ann Diagn Pathol 2001; 5: 267-273

26 Nowell PC. Mechanisms of tumor progression. Cancer Res 1986; 46: 2203-2207

27 Shackney SE, Smith CA, Miller BW, Burholt DR, Murtha K, Giles HR, Ketterer DM, Pollice AA. Model for the genetic evolution of human solid tumors. Cancer Res 1989; 49: 3344-3354

28 Bagwell CB, Clark GM, Spyratos F, Chassevent A, Bendahl PO, Stal O, Killander D, Jourdan ML, Romain S, Hunsberger B, Baldetorp. Optimizing flow cytometric DNA ploidy and $\mathrm{S}$ phase fraction as independent prognostic markers for nodenegative breast cancer specimens. Cytometry 2001; 46: 121-135 


\section{Serum and tissue levels of apoptosis in benign and malignant endometrium}

H.J.M.M. Mertens, M.P. Leers, M. Nap, J.E.M. Degen, J.E.G.M. Stoot, N. Kisters, S. Linder, M.J. Heineman, J.L.H. Evers (submitted) 


\section{Abstract}

Apoptosis plays a crucial role in cancer development and cancer progression. The level of apotosis and proliferation are investigated in 112 patients with either normal inactive postmenopausal endometrium, endometrial hyperplasia or endometrial cancer. Besides the measurement of expression of the apoptotic marker $M_{30}$ in the endometrial tissue, an assay became available which recognizes the caspase-cleaved CK fragments in serum. The relation between the apoptotic activity, measured in endometrium and in serum, the proliferation activity and the tumor stage was investigated.

Peripheral serum levels of $M_{3} 0$ were not different between patients with or without endometrial cancer. Pelvic serum levels of $M_{30}$ and tissue $M_{30}$ levels increased from normal to hyperplastic endometrium, to endometrial cancer. The S-phase fractions were higher in endometrial cancer than in benign endometrium.

The balance of proliferation and apoptosis gives more insight in endometrial carcinogenesis.

The treatment and prognosis of endometrial cancer are dependent on the FIGO stage of the tumor. Pelvic $M_{30}$ serum levels or $M_{30}$ tissue levels may yield information to select a subgroup of patients within endometrial cancer FIGO stage IB who will benefit from adjuvant radiotherapy. 


\section{Introduction}

Endometrial cancer is the most common cancer of the female genital tract in developed countries (1). Epithelial endometrial malignancies are supposed to develop out of hyperplastic endometrium (2). Distinct changes in the level of cell proliferation, apoptosis and anti-apoptosis between normal endometrium, endometrial hyperplasia and endometrial cancer have been described by Morsi and coworkers ( 3 ). They found a correlation between tumor grade and the level of apoptosis in the tumor.

Also in other types of cancer such correlation has been described (4). In colon cancer, the level of apoptosis, determined by multiparameter flow cytometry (MP.FCM), was a stronger predictor for survival than the Dukes Staging, which nowadays is used in routine practice (4).

Similar to colon cancer, the prognosis of endometrial cancer is associated with tumor stage. The majority of patients with endometrial cancer are diagnosed as having FIGO stages IA and IB disease (1). Based on the multinational PORTEC trial, adjuvant therapeutic strategies, after surgical treatment, are dependent on the FIGO stage of the endometrial cancer, the tumor invasion, the patients' age and the histologic grade of the tumor $(5,6)$. Based on these criteria, most patients with stage IB endometrial cancer get adjuvant radiotherapy. At present, there are no additional parameters that can separate patients within this group that might do well or might not do well without adjuvant radiotherapy.

In the present study we investigated a possible relation between the level of apoptotic activity in the tumor, the tumor stage and the serum level of $M_{30}(7)$ in patients with endometrial cancer. Three-parameter flow cytometric assays allowed for simultaneous assessment of the extent of proliferation (S-phase fraction) as well as the fraction of early apoptotic epithelial cells ( $\mathrm{M}_{3} 0$ positive fraction) in benign and malignant endometrium. Within the group of endometrial cancer FIGO stage IB, we tried to identify a subgroup of patients with a different prognostic subtype.

\section{Materials and Methods}

Blood was sampled in 112 postmenopausal patients who underwent an abdominal hysterectomy with salpingo-oophorectomy at the Atrium Medical Center hospitals in either Heerlen or Brunssum because of endometrial cancer $(n=90)$ or benign gynaecologic conditions $(n=22)$. Flow cytometric analysis was performed on all 22 patients without and on 35/90 patients with endometrial cancer.

Ethical approvement and patients' consent were obtained for scientific research on endometrial biopsies and serum samples.

\section{Patients' characteristics}

All patients were postmenopausal, i.e. more than 12 months had elapsed since their last menstrual period. None of them used steroid medication or was suffering from ovarian pathology.

The ages of the patients without endometrial cancer varied from 45 to 81 years. The patients' ages in the group of patients with endometrial cancer varied from 49 to 89 years. There was no difference in time interval since menopause between the group of patients without or with endometrial cancer (median duration 19.4 versus 16.3 
months). Patients with endometrial cancer were significantly more obese than patients without (Body Mass Index $31.3 \pm 2.1$ versus $26.0 \pm 1.8)(p=0.012)$.

Most patients with endometrial cancer were diagnosed as having low stage disease: $30 \%$ was classified as $\mathrm{FIGO}$ stage IA, $31 \%$ as $\mathrm{FIGO}$ stage IB and $21 \%$ as $\mathrm{FIGO}$ stage IC endometrial cancer. Eighteen per cent of the patients with endometrial cancer was suffering from higher stage disease ( $5 \%$ patients from $\mathrm{FIGO}$ stage $2 \mathrm{~A} ; 2 \%$ from $\mathrm{FIGO}$ stage $2 \mathrm{~B} ; 3 \%$ from FIGO stage $3 \mathrm{~A}$, stage $3 \mathrm{~B}$ and stage $4 \mathrm{~A}$; and $2 \%$ from FIGO stage 4B).

\section{Endometrial characteristics}

Histologic examination of benign endometrium showed normal postmenopausal endometrium in 13/22 (59\%) cases; hyperplasia without atypia in 4/22 (18\%); and hyperplasia with atypia in $5 / 22(23 \%)$. In the group of patients with endometrial cancer the tumor was classified histopathologically as low grade endometrial cancer (Grade I) in 33/90 (37\%), intermediate grade endometrial cancer (Grade II) in 32/90 (35\%), and high grade (Grade III) or papillary serous tumors in $25 / 90$ (28\%).

\section{Serum analysis}

\section{Sampling procedure}

Blood was sampled from an antecubital vein preoperatively and from the uteroovarian plexus at either side peroperatively. The peripheral blood samples were taken before any fluid, blood transfusion or medication was administered intravenously. Immediately after the peritoneum was opened, i.e. shortly after the operation had started, the local blood samples were taken. The procedure of pelvic blood sampling has been described previously (8).

In five patients, in whom one ovary was missing because of previous gynaecologic procedures, the remaining contralateral utero-ovarian venous plexus was successfully sampled in all of them.

\section{Serum assay of $\mathbf{M} 30$}

96-well microtiter plates (Costar Stripwell TM \#92592) were coated with monoclonal antibody $5 \mathrm{E}$ directed against an epitope on the 284.396 fragment of CK18. Monoclonal antibody $\mathrm{M}_{30}$ was conjugated to horseradish peroxidase (Sigma Type XII \#P.8415) according to standard methods. Antigen used as a standard for converting A450 readings to $\mathrm{U} / \mathrm{I}$ was purified from apoptotic WiDr colon cancer cells $(9)$. For each assay, $25 \mu \mathrm{l}$ of culture medium or cell extract was used.

\section{Endometrial cell analysis}

\section{Preparation of cell suspension}

For the preparation of the single cell suspension, the technique described in a previous report was used (10). Briefly, for every assay, two $50 \mu \mathrm{m}$ thick sections were cut from each paraffin block. Subsequently, these tissue sections were deparaffinized twice in xylene, 30 minutes each, and rehydrated in a descending ethanol series. Sections were rinsed in phosphate buffered saline (PBS; pH 7.2-7.4). The sections 
were placed in a glass tube with cold citrate solution $(2 \mathrm{mg}$ citric acid/ml aqua dest; $\mathrm{pH}=6.0$ ), and subjected to a 120 minute heating step in an $80^{\circ} \mathrm{C}$ water bath. After a short cooling period, a freshly prepared solution of $1 \mathrm{mg} / \mathrm{ml}$ pepsin (Sigma, St. Louis, MO, USA) in $0.1 \mathrm{~N} \mathrm{HCl}$ was added at room temperature and allowed to digest for 10 minutes at $37^{\circ} \mathrm{C}$. A single cell suspension was obtained by vortexing and filtrating the sample through a $50 \mu \mathrm{m}$ mesh nylon filter. The cell suspension was centrifuged at $400 \mathrm{~g}$ and the cell pellet was resuspended in $200 \mu \mathrm{l} \mathrm{PBS}$, supplemented with $1 \%$ bovine serum albumin (BSAVPBS buffer; Sigma).

\section{Multiparameter Flow Cytometry}

The single cell suspension was aliquoted into $100 \mu \mathrm{l}$ samples (approximately $10^{\circ}$ cells per $100 \mu$ PBS). To each sample both properly diluted monoclonal and polyclonal antibodies were added simultaneously: the epithelial cells were identified with polyclonal pancytokeratin (Zo622, Dako, diluted 1:500), and apoptotic cells with the monoclonal antibody against $\mathrm{M}_{30}$ (M30-cytodeath, Roche, Boeringer Manheim, Germany, diluted 1:100). An overnight incubation at room temperature was followed by a double PBS rinsing step. The reaction of the primary antibodies was visualized by incubating the cell pellet simultaneously with the secondary antibodies, i.e. goatanti-mouse-Ig-FITC (Dako, diluted 1:10) for the monoclonal antibody, and goat-antirabbit-Ig-RPE for the polyclonal antibody (Southern Biotechnology Association, Inc, Birmingham, Alabama, USA; diluted 1:12) for $11 / 2$ hours at room temperature. The samples were rinsed in PBS two times and finally DNA was stained using propidium iodide (PI, $1.0 \mu \mathrm{g} / \mathrm{ml}$, Sigma) in PBS containing $0.1 \mathrm{mg} / \mathrm{ml}$ RNAse (Sigma). The samples were allowed to stand for minimal 1 hour in the dark at $4^{\circ} \mathrm{C}$ before flow cytometric analysis. As a negative control for background staining by the primary antibody, a portion of the cell suspension was incubated with a non-relevant mouse immunoglobulin (DAKO A/S).

\section{Flow cytometric analysis}

Samples were analyzed using a DAKO Galaxy flow cytometer (provided for this study by DAKO). Cells were excited with a single $488 \mathrm{~nm}$ air-cooled Argon ion laser. FITCfluorescence was detected through a $520 \mathrm{~nm}$ BP filter, RPE-fluorescence through a 590 $\mathrm{nm}$ BP filter and PI-fluorescence through a $630 \mathrm{~nm}$ LP filter. At least 20,000 relevant events were collected for each sample. FITC- and RPE-signals were recorded as logarithmic amplified data, while PI-signals were recorded as linear amplified data. The following settings were used: $512 \mathrm{~V}, 360 \mathrm{~V}$ and $438 \mathrm{~V}$ on photomultiplier tubes for $\mathrm{FL}_{1}$ ( $\mathrm{FITC}$ ), FL2 (RPE) and $\mathrm{FL}_{3}(\mathrm{PI})$, respectively. A software-based compensation was performed afterwards using the Flomax Software (Partec GmbH, Münster, Germany). Cell cycle analysis was performed using Modfit LT 2.0 (Verity Software House Inc, Topsham, Maine, USA). The following data were collected:

1. The percentage of $M_{3} 0$-positive cells in the total epithelial compartment.

2. DNA-index and S-phase fraction of the total epithelial cell population as well as of the diploid and aneuploid epithelial cell population selectively.

3. The number of positive cells was determined in the cell suspension by an arbitrary threshold setting allowing not more than $5 \%$ positive counts in the negative control. 


\section{Statistical analysis}

Values of $\mathrm{M}_{30}$ tissue content and S-phase fractions are expressed in percentages of positive epithelial cells (mean \pm standard deviation). Values of $M_{30}$ serum concentrations are expressed in Units/liter.

The student T-test and the Mann-Whitney U-test were used whenever appropriate to determine statistically significant differences between groups. Besides, we used the Kruskal-Wallis test to determine statistically significant decrease or increase of a marker between all different subgroups. A p-value less than 0.05 was considered to reflect statistically significant differences.

\section{Results}

No significant differences were seen between $M_{30}$ serum levels in the utero-ovarian veins of either side in individual patients (data not shown); for further analyses we used the mean concentration of the two sides. In patients who previously had one ovary removed, $\mathrm{M}_{30}$ concentrations in the serum from the remaining side were used for analysis. Pelvic $\mathrm{M}_{30}$ levels were higher in patients with than in patients without endometrial cancer ( $246.6 \pm 185.9 \mathrm{U} / \mathrm{l}$ versus $151.3 \pm 58.0 \mathrm{U} / \mathrm{l})$ (pro.0001).

Peripheral $\mathrm{M}_{30}$ levels were not significantly different between patients with or without endometrial cancer: $171.6 \pm 138.9 \mathrm{U} / \mathrm{l}$ versus $122.7 \pm 65.5 \mathrm{U} / \mathrm{l}$. The tissue content of M30 was higher in endometrial cancer than in benign endometrial cells $(21.2 \pm 6.3 \%$ versus $12.2 \pm 5.5 \%$ respectively) (pro.0001).

All benign endometrium samples had a diploid DNA content. The mean S-phase fraction in endometrial cancer seemed to be higher than in benign endometrium (10.2 $\pm 6.2 \%$ versus $6.1 \pm 3.0 \%$ ) (NS).

\section{Normal postmenopausal inactive endometrium}

The mean peripheral $M_{30}$ serum level in patients with normal inactive endometrium was $96.5 \pm 41.2 \mathrm{U} /$; the mean local $M_{30}$ serum level was $115.5 \pm 52.9 \mathrm{U} / \mathrm{l}$. M30 tissue content in normal inactive endometrium was $10.8 \pm 6.1 \%$. In Table 1, peripheral and local $M_{30}$ serum levels and tissue $M_{30}$ content are shown.

The S-phase fraction in normal inactive endometrium was $6.2 \pm 3.3 \%$.

\section{Hyperplastic endometrium}

In hyperplastic endometrium without and with atypia, peripheral serum $\mathrm{M}_{30}$ levels were $92.0 \pm 25.5 \mathrm{U} / \mathrm{/}$ and $119.5 \pm 105.2 \mathrm{U} / \mathrm{l}$; local $M_{30}$ serum levels were $134.5 \pm 72.2$ $\mathrm{U} / \mathrm{A}$ and $152.0 \pm 59.8 \mathrm{U} / \mathrm{/}$ respectively. Tissue $\mathrm{M}_{3} 0$ content in hyperplastic endometrium without and with atypia was $10.8 \pm 3.0 \%$ and $13.8 \pm 6.8 \%$ respectively. Differences between peripheral and local $M_{30}$ serum levels and tissue $M_{30}$ content between normal inactive and hyperplastic endometrium were not statistically significant.

The S-phase fraction in hyperplastic endometrium without atypia was $5.3 \pm 0.8 \%$; in hyperplastic endometrium with atypia $8.9 \pm 2.2 \%$. The S-phase fraction did not differ significantly between inactive and hyperplastic endometrium. 


\section{Endometrial cancer}

Mean peripheral serum $\mathrm{M}_{30}$ levels in endometrial cancer were $135.0 \pm 93.7 \mathrm{U} / \mathrm{/}$ for Grade I; $115.0 \pm 293.1 \mathrm{U} / \mathrm{l}$ for Grade II; and $101 \pm 74.2$ U/I for Grade III respectively. Local $M_{30}$ levels increased from Grade I to Grade II and increased further to Grade III endometrial cancer (178.0 $\pm 165.5 \mathrm{U} / \mathrm{l}$ to $203.3 \pm 161.9 \mathrm{U} / \mathrm{l}$ to $216.5 \pm 72.1 \mathrm{U} / \mathrm{l}$ () (NS). M30 tissue content in Grade I cancer was low (17.3 $\pm 3.0 \%$ ) It was increased in Grade II cancer $(21.1 \pm 4.2 \%)(p=0.019)$ and increased further in Grade III endometrial cancer $(28.7 \pm 5.8 \%$ ) (pro.001).

The S-phase fractions were $6.8 \pm 3.3 \%$ for Grade I; $9.2 \pm 4.2 \%$ for Grade II and 15.1 $\pm 7.7 \%$ for Grade III endometrial cancer.

Table 1 Serum M30 (U/N) and tissue $M_{30}(\%)$ in patients without and with endometrial cancer

M30 in peripheral and pelvic serum (U/1), and tissue $M_{30}(\%)$ in patients with benign endometrium and in patients with endometrial cancer. In the columns, corresponding letters mean non-significant differences; different letters mean significant differences.

\begin{tabular}{|l|c|c|c|}
\hline & $\begin{array}{c}\text { Peripheral } \\
\text { serum }\end{array}$ & $\begin{array}{c}\text { Pelvic } \\
\text { serum }\end{array}$ & Tissue \\
\hline Normal endometrium & $96.5 \pm 41.2$ & $115.5 \pm 52.9 \mathrm{a}$ & $10.8 \pm 6.1 \mathrm{ab}$ \\
\hline Endometrium + hyperplasia & $92.0 \pm 25.5$ & $134.5 \pm 72.2 \mathrm{ab}$ & $13.8 \pm 6.8 \mathrm{ab}$ \\
\hline Endometrium + hyperplasia + atypia & $119.5 \pm 105.2$ & $152.0 \pm 59.6 \mathrm{ab}$ & $10.8 \pm 3.0 \mathrm{a}$ \\
\hline Grade I carcinoma & $135.0 \pm 93.7$ & $178.0 \pm 165.5 \mathrm{ab}$ & $17.3 \pm 3.0 \mathrm{~b}$ \\
\hline Grade II carcinoma & $115.0 \pm 239.1$ & $172.3 \pm 261.9 \mathrm{ab}$ & $21.1 \pm 4.2 \mathrm{c}$ \\
\hline Grade III carcinoma & $101.0 \pm 74.2$ & $216.5 \pm 72.1 \mathrm{bc}$ & $28.7 \pm 5.8 \mathrm{c}$ \\
\hline
\end{tabular}

\section{Heterogeneity of endometrial cancer in relation to DNA ploidy}

In the group of Grade I endometrial cancers the majority of tumors were diploid $(12 / 14,86 \%)$. One out of two non-diploid tumors showed a tetraploid DNA-profile and the other showed a DNA index of 1.20 . Of all Grade II tumors only 3/13 (23\%) were diploid: the DNA index of the aneuploid tumors varied from 1.20 to 2.20 . Three out of 10 non-diploid Grade II tumors were tetraploid. Of all Grade III endometrial cancers $2 / 8(25 \%)$ were diploid. The DNA index of the aneuploid tumors varied from 1.26 to 2.16. None were tetraploid. The percentages of aneuploidy in Grade II cancers (pro.0001) and III cancers (pro.0001) were significantly higher than in Grade I tumors. Besides, the percentages of tetraploidy amongst the tumors were significantly different between Grade I and Grade II tumors (pro.001) versus Grade III tumors (pro.001).

The S-phase fractions of the diploid versus the aneuploid tumor fractions in the group of Grade I, Grade II and Grade III endometrial cancers were $7.3 \pm 3.7 \%$ versus $31.4 \pm$ $10.0 \%$ for Grade I; $9.6 \pm 4.7 \%$ versus $33.3 \pm 5.4 \%$ for Grade II and $12.4 \pm 4.7 \%$ versus $34.5 \pm 10.1 \%$ for Grade III endometrial tumors (Table 2). Irrespective of the Grade of tumor, the difference in S-phase fractions of the aneuploid tumor fractions compared to the diploid tumor fractions within one tumor was statistically significant (pro.0001). 
Table 2 S-phase fraction in Grade I, II and III endometrial cancer

S-phase fraction (\%) and its heterogeneity in peripheral and pelvic serum in patients with Grade I, Grade II and Grade III endometrial cancer. In the rows and columns, corresponding letters mean non-significant differences; different letters mean significant differences.

\begin{tabular}{|l|c|c|c|}
\hline & $\begin{array}{c}\text { Grade I } \\
\text { carcinoma }\end{array}$ & $\begin{array}{c}\text { Grade II } \\
\text { carcinoma }\end{array}$ & $\begin{array}{c}\text { Grade III } \\
\text { carcinoma }\end{array}$ \\
\hline S-phase, total fractions & $6.8 \pm 3.3 \mathrm{a}$ & $9.2 \pm 4.2 \mathrm{ad}$ & $15.1 \pm 7.7 \mathrm{ad}$ \\
\hline S-phase, diploid fraction & $7.3 \pm 3.7 \mathrm{a}$ & $9.6 \pm 4.7 \mathrm{a}$ & $12.4 \pm 4.7 \mathrm{a}$ \\
\hline S-phase, aneuploid fraction & $31.4 \pm 10.0 \mathrm{~b}$ & $33.3 \pm 5.4 \mathrm{~b}$ & $34.5 \pm 10.1 \mathrm{~b}$ \\
\hline
\end{tabular}

Figure 1
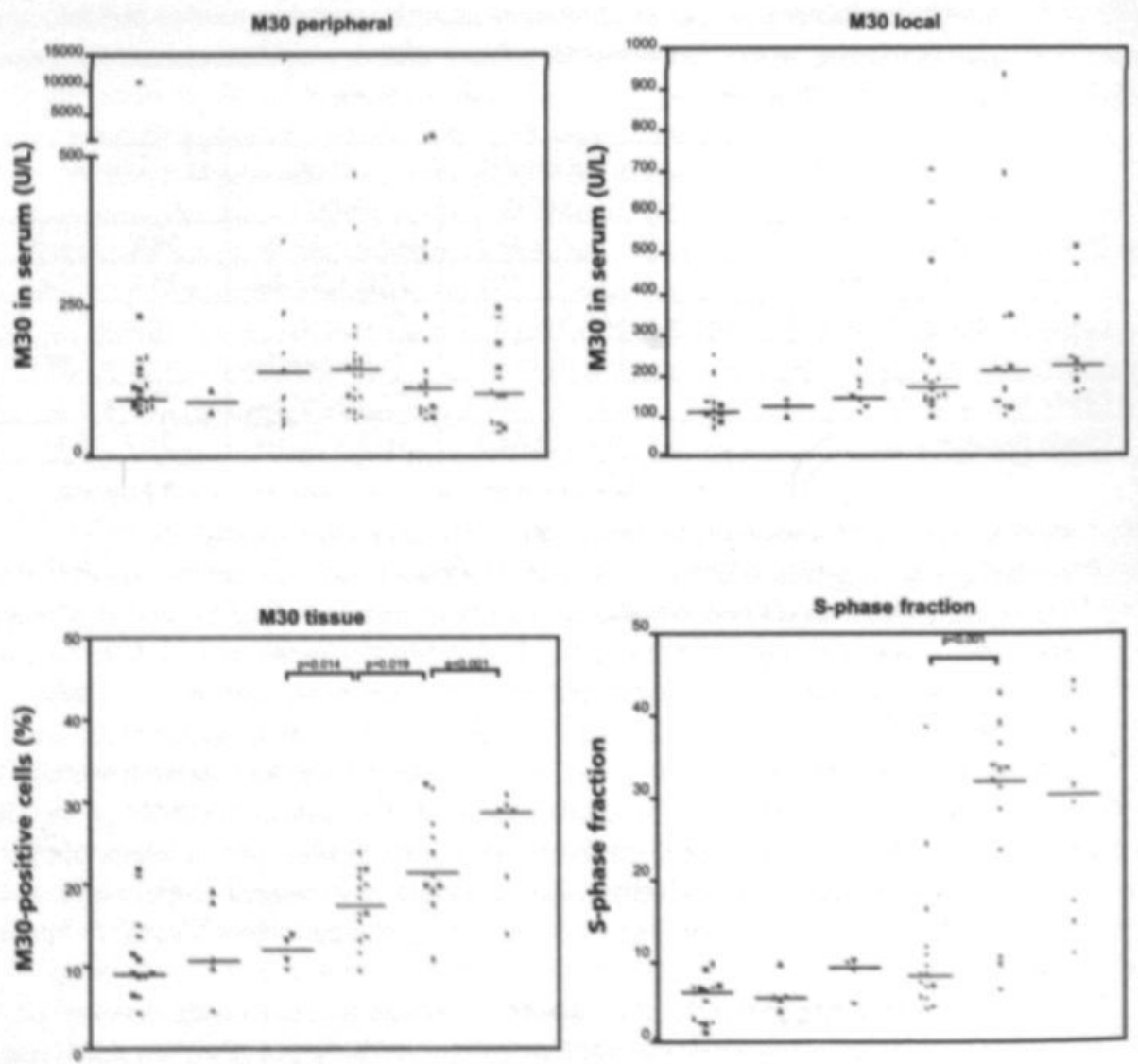

\section{Legend Figure 1}

Peripheral $M_{30}$ serum levels, local $M_{30}$ serum levels, tissue $M_{30}$ levels and the $S$ phase fraction in patients without and with endometrial cancer 


\section{M30 serum and M30 tissue levels in relation to the FIGO stage}

Peripheral $\mathrm{M}_{30}$ levels did not correlate with the FIGO stage of the endometrial cancer (figure 2). Tissue $\mathrm{M}_{30}$ content in samples with endometrial cancer FIGO stage IC was significantly higher than $\mathrm{M}_{30}$ content in samples with endometrial cancer FIGO stage IA ( $16.2 \pm 3.7 \%$ versus $25.2 \pm 4.8 \%$ ). Also local M30 serum levels were higher in patients with FIGO stage IC versus stage IA endometrial cancer $(247.6 \pm 177.5 \mathrm{U} / \mathrm{A}$ versus $168,0 \pm 73.8 \mathrm{U} / \mathrm{O}$.

Patients with endometrial cancer FIGO stage IB pointed out to have either high $\mathrm{M}_{30}$ tissue content $(20 \%)$, not significantly different from $\mathrm{M}_{30}$ tissue content in patients with endometrial cancer FIGO stage IC ( $23.6 \pm 4.0 \%$ versus $25.2 \pm 4.8 \%)$; or to have low M30 tissue content ( $220 \%$ ), not significantly different from patients with endometrial cancer FIGO stage IA (13.4 $\pm 1.9 \%$ versus $16.2 \pm 3.7 \%)$. Endometrial $\mathrm{M}_{30}$ content in patients with FIGO stage II, III and IV was high in all casus but one (figure 2). In patients with endometrial cancer Figo stage IB, the S-phase fractions and percentage of aneuploidy between the subgroups of patients with low versus with high tissue $\mathrm{M}_{30}$ content were not significantly different. In the subgroup of patients with endometrial cancer FIGO stage IB and high $\mathrm{M}_{30}$ tissue content, the local serum $\mathrm{M}_{30}$ levels were higher compared to the local serum $\mathrm{M}_{30}$ levels of the subgroup of patients with low M30 tissue ( $264 \pm 177.4 \mathrm{U} / \mathrm{l}$ versus $178.0 \pm 98.5 \mathrm{U} / \mathrm{D}$ (NS).
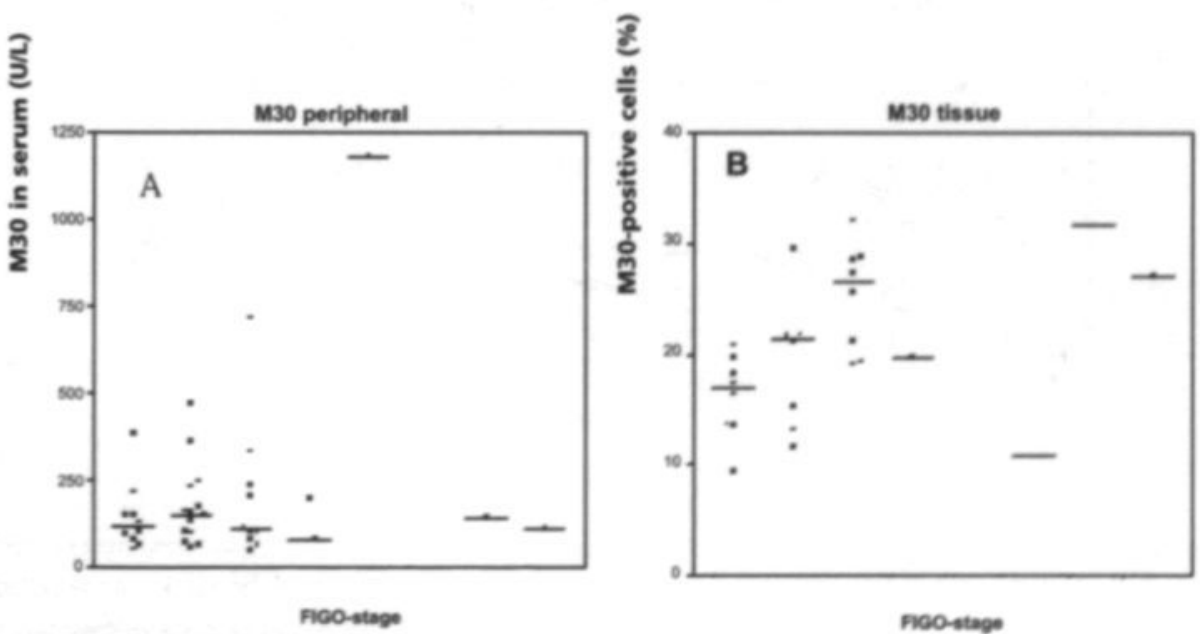

\section{Legend Figure 2}

Peripheral $M_{30}$ serum levels and tissue $M_{30}$ content in patients with endometrial cancer of all FIGO stages 


\section{Discussion}

Apoptosis plays, next to proliferation, a crucial role in carcinogenesis (figure 3 ). The role of apoptosis in cancer development and cancer progression has been demonstrated both in vitro and in vivo. The process of apoptosis may be investigated with several laboratory methods, which focus on different aspects of the biological phenomenon. The production of stable fragments of human type I cytokeratins has been shown to be a characteristic feature of apoptosis (11). With cytokeratin serum assays (TPA, cyfra 21-1), it has been demonstrated that increased serum values correlate with a high apoptosis rate in cell lines (12).

Recently, a new serum assay has been developed which specifically recognizes the caspase-cleaved CK 18 fragment recognized by $M_{30}(7)$. During increased cellturnover, it is thought that cytokeratin fragments generated by apoptosis, will be released in blood and lymph vessels.

\section{Figure 3 Apoptosis versus proliferation in benign and malignant endometrium}

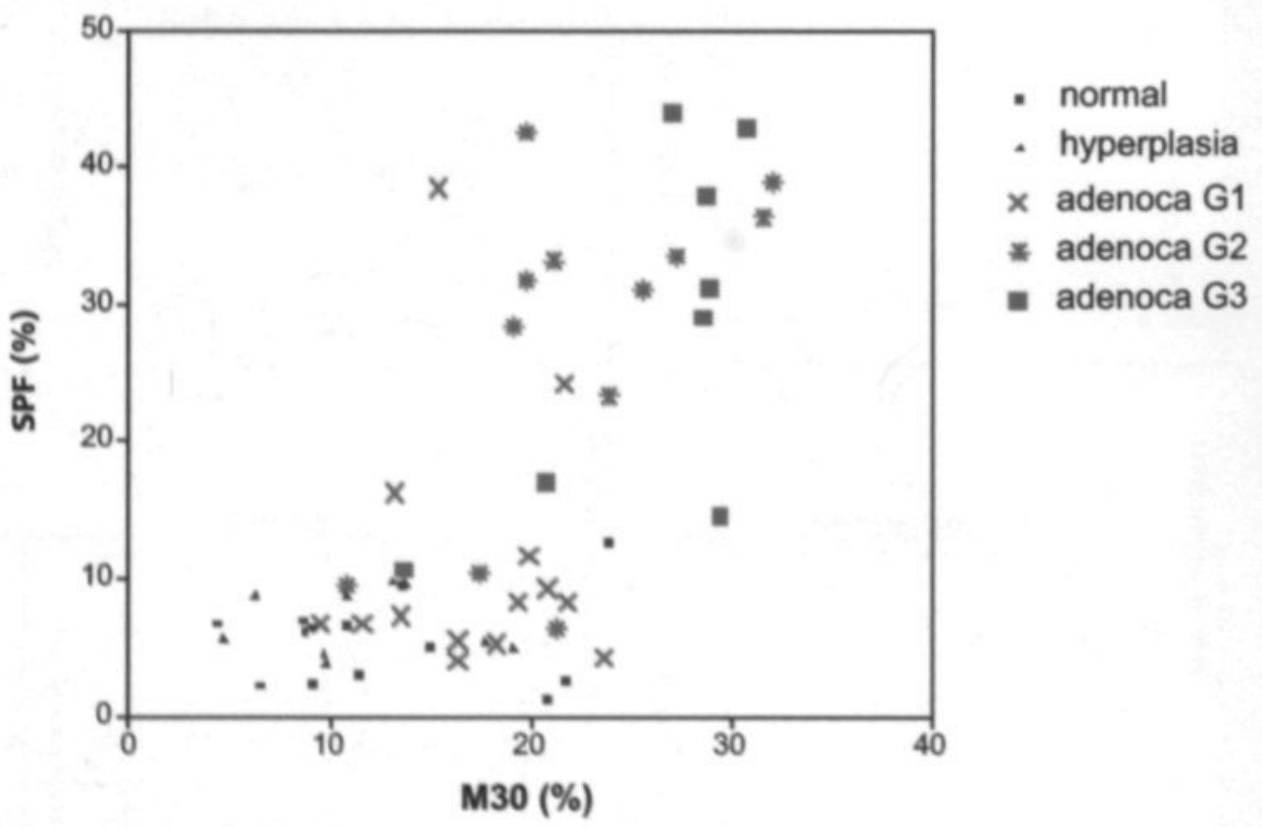

In general, serum markers, used to study patients with endometrial cancer often reflect the presence or absence of uterine serosal involvement or distant metastasis (13). It is therefore unlikely that such an approach will discriminate patients within the FIGO stage IB group. Although a small difference could be found in levels of serum M30 between patients with benign endometrial morphology and patients with endometrial cancer, this was clearly seen in serum samples from local veins. Studies concerning apoptosis or anti-apoptosis $(3,14)$ show similar findings as demonstrated 
in the present study. The quantification of apoptosis in tissue by MP.FCM has shown in other tumor systems to be a stronger separator than the Dukes staging procedure, used in routine practice (4). Although the prognosis of patients with endometrial cancer tends to be good, it might be that the level of apoptosis could add an additional classification criterium to identify patients with a fouvarable prognosis without adjuvant therapy.

The results of the PORTEC trial have lead to the policy to treat patients with FIGO stage IB with adjuvant radiotherapy depending on their age, myometrial involvement and the tumor Grade (5). In our study, we included 19 patients with endometrial cancer FIGO stage IB. Within this group, high $\mathrm{M}_{30}$ tissue content was associated with high local serum $M_{30}$ levels. Although the numbers are small, these findings may indicate that there is a chance to identify patients with different risk factors within FIGO stage IB endometrial cancer.

Avoidance of radiotherapy for some of the patients with FIGO stage IB disease, based on the level of apoptosis, may prevent the side effects of radiotherapy for the individual patient. In addition, since FIGO stage IB disease account for the majority of endometrial cancer stages at first diagnosis (1), this may result in considerable cost savings on a treatment/patients basis. Since $M_{30}$ can be determined reliably by MP. FCM on formalin fixed paraffin embedded material from archival blocks, a retrospective study on the value of $\mathrm{M}_{30}$ as an additional classification criterium in FIGO stage IB endometrial cancer should be performed.

\section{References}

1 Visser 0, Coebergh JWW, Schouten LJ, van Dijck JAAM. Incidence of cancer in the Netherlands 1997. Netherlands Cancer Registry, VIKC 2001

2 Ohkawara S, Jobo T, Sato R, Kuramoto H. Comparison of endometrial carcinoma coexisting with and without endometrial hyperplasia. Eur J Gynaecol Oncol 2000; 21(6): 573-577

3 Morsi HM, Leers MPG, Radespiel-Troger M, Bjorklund V, El Kabarity H, Nap M, Jager W. Apoptosis, Bcl-2 expression and proliferation in benign and malignant endometrial epithelium: an approach using multiparameter flow cytometry. Gynecol Oncol 2000; 77: 11-17

4 Rupa JD, de Bruine AP, Gerbers AJ, Leers MPG, Nap M, Kessels AGH, Schutte B, Arends JW. Simultaneous detection of apoptosis and proliferation in colorectal cancer by multiparameter flow cytometry allows separation of high and low turnover tumours with distinct clinical outcome. Cancer 2002; in press

5 Creutzberg CL, van Putten WL, Koper PC, Lybeert ML, Jobsen IJ, WarlamRodenhuis CC, de Winter KA, Lutgens LC, van den Bergh AC, van de SteenBanasik E, Beerman $\mathrm{H}$, van Lent $\mathrm{M}$. Surgery and postoperative radiotherapy versus surgery alone for patients with stage I endometrial carcinoma: multicentre randomised trial. PORTEC Study Group. Post Operative Radiation Therapy in Endometrial Carcinoma. Lancet 2000; 355: 1404-1411

6 Benedet JL, Bender H, Jones H $3^{\text {t" }}$, Ngan HY, Pecorelli S. FIGO staging classifications and clinical practice guidelines in the management of gynecologic cancers. FIGO Committee on Gynecologic Oncology. Int J Gynaecol Obstet 2000; 70: $209-262$ 
7 Hagg M, Biven K, Takayuki U, Rydlander L, Bjorklund P, Wiman KG, Shoshan M, Linder S. A novel high-through-put assay for screening pro-apoptotic drugs. Investigational New Drugs 2002; 20: 253-259

8 Heineman MJ, Sluijmer AV, Evers JLH. Utero-ovarian vein blood sampling in postmenopausal women. Fertil Steril 1993; 60: 184-186

9 Rydlander L, Ziegler E, Bergman T, Schoberl B, Steiner G, Bergman AC, Zetterberg A, Marberger M, Bjorklund P, Skern T, Einarsson R, Jornvall H. Molecular characterization of a tissue-polypeptide-specific-antigen epitope and its relationship to human cytokeratin. Eur J Biochem 1996; 241: 3009-314

10 Leers MPG, Kolgen W, Bjorklund V, Bergman T, Tribbick G, Persson TB, Bjorklund P, Ramaekers FCS, Nap M, Schutte B. Immunocytochemical detection and mapping of a cytokeratin 18 neo-epitope exposed during apoptosis. J Pathology 1999: $187 ; 567.572$

$11 \mathrm{Ku} \mathrm{NO}$, Liao J, Omary MB. Apoptosis generates stable fragments of human type I keratins. I Biol Chem 1997; 272: 33197-33203

12 Dittadi R, Coradini D, Meo S, Pironello E, Daizone MG, Gion M. Tissue polypeptide antigen as a putative indicator of apoptosis. Clin Chemistry 1998; 44: 9

13 Ginath S, Menczer J, Fintsi Y, Ben-Shem E, Glezerman M, Avinoach I. Tissue and serum $\mathrm{CA}_{125}$ expression in endometrial cancer. J Clin Gynecol Cancer 2002; 12: 372-375

14 Morsi HM , Leers MPG, Jager W, Bjorklund V, Radespiel-Troger M, El Kabarity H, Nap M, Lang N. The patterns of expression of an apoptosis-related CK18 neoepitope, the $\mathrm{Bcl}-2$ proto-oncogene, and the $\mathrm{Ki} 67$ proliferation marker in normal, hyperplastic, and malignant endometrium. Int J Gynecol Pathol 2000; 19: 118-126 


\section{CHAPTER 9}

\section{General discussion and recommendations}

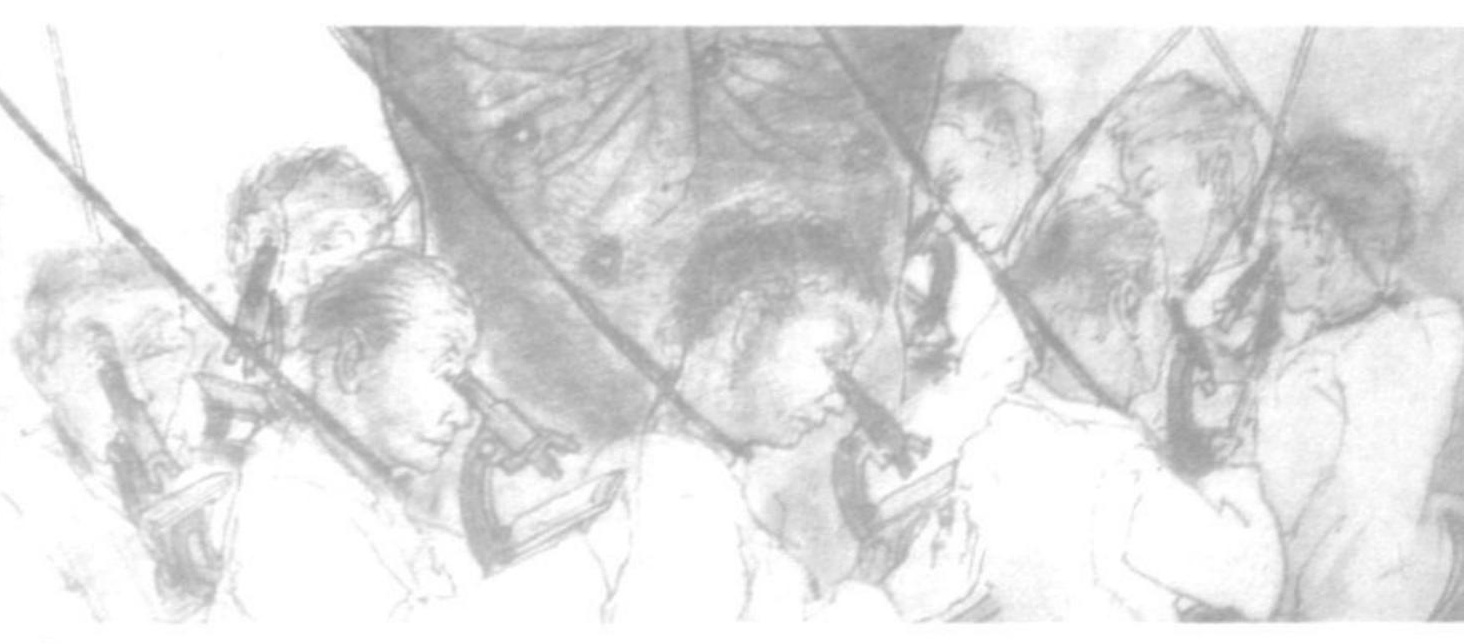




\section{General discussion}

The first aim of this thesis was to study cyclic changes in endometrium as related to steroid hormone levels, steroid hormone receptor content, tissue proliferation and apoptosis in normal premenopausal women. We found cyclic changes in steroid hormone receptor expression. Besides the cyclic changes of estrogen receptor (ER) and progesterone receptor (PR) content in the individual layers of the endometrium, which showed the same cyclic patterns as was documented already in literature, androgen receptor (AR) content decreased from the menstruation phase, to the proliferative phases. AR content further decreased in the early and mid secretory phases; in the late secretory phase AR content was absent in all individual layers of the endometrium.

We speculated that the lack of immunostaining for AR in the late secretory phase might be due to the local competition between testosterone and the excess of progesterone for $5 \alpha$-reductase. While the level of $s \alpha$-reduction of testosterone and therefore the level of DHT will be diminished, AR synthesis in the endometrium will disappear as a result of feedback inhibition.

After menopause, we saw relatively high AR in benign endometrial epithelium as compared to endometrial epithelium of premenopausal women. The lack of progesterone and thus the loss of competitive inhibition of testosterone conversion to DHT may explain the relatively high AR content in normal inactive postmenopausal endometrium.

The second aim of this thesis was to study the peripheral and local endocrine milieus in postmenopausal patients with and without endometrial cancer. Local unbound and bound androgens, in contrast to local unbound and bound estrogens, are higher in patients with than in patients without endometrial cancer.

In postmenopausal patients without endometrial cancer, local estrogen concentrations were not significantly different between patients with and patients without endometrial hyperplasia. However, local androgens were higher in patients with endometrial hyperplasia than in patients with normal inactive endometrium $(p=0.039)$ (unpublished data). Also AR content was higher in endometrial hyperplasia than in normal inactive postmenopausal endometrium. The AR in premenopausal endometrium was relatively high in the proliferative phases of the normal menstrual cycle. We suggest that local androgens and its receptors have an important role in the development of physiologic endometrial proliferation and on pathologic endometrial proliferation like endometrial hyperplasia and endometrial carcinogenesis.

About the increasing interest of androgen replacement therapy in symptomatic women undergoing menopause (1-4), Slayden concluded that the safety profile is acceptable for 'non-supraphysiologic' testosterone levels. Besides the increased risk for virilizing effects and hepatic damage, the risks for developing endometrial hyperplasia and endometrial cancer should be considered as well, as is suggested by our results. Whether exogenous administered androgens may affect local tissue androgen levels, is not known; neither is the effect known of exogenous androgens in competition or collaboration with endogenous androgens. 
The third aim of this thesis was to document steroid hormone receptor content, and proliferation and apoptosis markers in postmenopausal physiologic and pathologic endometrium.

AR content is even higher in endometrial hyperplasia and endometrial cancer cells than in normal inactive postmenopausal endometrial cells. From clinical practice, we know that patients with endometrial hyperplasia will commonly respond to treatment with progestational agents; patients who do not respond are at an increased risk for endometrial cancer (5). The response to progesterone can not be predicted however, by the steroid hormone receptor status of the hyperplastic endometrium (6-8).

We hypothesise that exogenous progesterone, like endogenous progesterone, could limit the $5 \alpha$-reduction of testosterone, so the intracellular availability of DHT. As a result, the AR content of endometrial cells decreases. However, in pathologic conditions, when the local pelvic levels of androgens are extremely high, the $5 \alpha$ reduction will persist in favour of $5 \alpha$-reduced testosterone due to the high concentration of testosterone, especially seen in patients with endometrial cancer. AR synthesis persists, AR content does not decrease and the inhibitory effect of progesterone on the progression of endometrial cancer fails: the patient does not respond'.

Endometrial hyperplasia is supposed to be a reflection of estrogenic effect on the endometrium. Estrogens are associated with cell proliferation. The level of ER in endometrial hyperplasia is higher indeed than in normal inactive postmenopausal endometrium, although the level of proliferation, measured by the S-phase fraction, is not higher in endometrial hyperplasia as compared to inactive endometrium. It was shown by Morsi and co-workers that in endometrial hyperplasia, the expression of $\mathrm{Bcl}$ 2 was higher than in normal postmenopausal endometrium (9). Based on our findings, it is tempting to speculate that the increased risk for endometrial cancer is more likely due to increased cell survival by apoptosis inhibition, than to increased endometrial cell proliferation.

The final aim of this thesis was to evaluate multiparameter flowcytometry in routine and research examination of the endometrium. The patient case history in chapter 5 illustrates the use of this technique for clinical practice. Research on physiologic endometrial processes as well as endometrial carcinogenesis requires information about many cell-cycle regulatory proteins and their inhibitors, steroid hormone receptors, DNA ploidy, markers for telomerase, apoptosis, proliferation, etc. The newer techniques like multiparameter flow cytometry enable valid, accurate and reproducible endometrial investigations compared to the present time-consuming subjective methods.

\section{Recommendations}

Despite all research into the physiologic processes of endometrial changes during the respective phases of the menstrual cycle, these processes are still not completely understood. This thesis shows that observational studies provide the opportunity to 
obtain information on human endometrium in vivo, which is needed to understand the physiologic and pathologic endometrial changes.

The knowledge of cyclic AR expression in premenopausal endometrium and relative AR overexpression in malignant endometrium suggests a more important role of androgens in physiologic and pathologic endometrial processes than was presumed until now. The understanding of the biological processes needs further research. In vitro studies of human endometrium in an androgen rich and androgen-deprived milieu may add further information about the function of androgens, the AR and its steroid control in this respect. Besides, the local effects of exogenous androgens on endometrial (cancer) cells and its inhibitors can be studied extensively in such research circumstances.

Whereas estrogens are associated with cell proliferation, and progesterone is associated with cell differentiation, the cellular effects of androgens on human endometrial cells require further investigations. They are supposed to be proliferative as well as differentiative, while activities of $T$ might be associated with cell differentiation, whereas DHT acts on cellular proliferation (10). Thijssen and coworkers have shown that the uterine tissue androgen concentrations of testosterone, androstenedione and dehydroepiandrosterone were higher than the corresponding plasma concentrations (11). In vivo studies with individual androgens will show their specific effect on endometrial (cancer) cells.

Also in in vitro studies, the role of apoptosis in human endometrium will have to be studied. From literature we know that estrogens and progesterone control both epithelial cell proliferation and cell death (12-15). Their regression appears to precede apoptosis. Anti-androgens or withdrawal of androgens are supposed to induce apoptosis in the glandular epithelium of the prostate (16). In parallel with human prostate tissue, in which the role of androgens and its receptors have been studied more extensively, human endometrial tissue will have to be investigated.

Estrogens and androgens in uterine and breast tissues are higher than in plasma, although the plasma/tissue gradient for individual androgens in uterine tissue is higher than in breast tissue $(11,17)$. Thijssen and co-workers concluded that the uterus proved more capable of concentrating androgens than the breast (19). In parallel with breast cancer, in which the role of estrogens and progesterone on ER and PR are studied extensively, endometrial cancer has to be investigated; the role of individual androgens and AR influences have to be studied in both (human) breast and endometrial cancer cells.

Both endometrial and breast tissue is able to influence their own hormonal milieu. In breast tissue, higher aromatase activities were found in tumor tissue versus fatty tissue from tumor bearing and non-tumor bearing quadrants (18-19). Van der Wall and co-workers described the possibility of complete inhibition of in vivo conversion of androstenedione to estrone in postmenopausal women (20). Further studies on (complete) inhibition of aromatase activity in endometrial (cancer) cells will enhance our knowledge on endometrial pathophysiology and carcinogenesis, especially on the direct role of androgens and AR.

In vitro studies on cell-cycle regulators involved in human endometrial (cancer) cells, 
as described by Milde-Langosch and co-workers (21) should also provide information of androgenic potentials and AR expression to increase our knowledge on endometrial carcinogenesis.

For clinical use, it should be investigated whether a threshold of AR content predicts the response to progesterone before embarking on safe conservative treatment of endometrial hyperplasia with progesterone. Besides, studies with larger numbers of patients will have to be done to differentiate between useful and fertile endometrial cell parameters for diagnostic purposes.

\section{References}

1 Davis SR. Androgen replacement in women: a commentary. J Clin Endocrinol Metab 1999; 84: 1886-1891

2 Sarrel P, Dobay B, Wiita B. Estrogen and estrogen-androgen replacement in postmenopausal women dissatisfied with estrogen-only therapy: sexual behaviour and neuroendocrine response. J Reprod Med 1998; 43: 847-856

3 Montgomery J, Brincat M, Appleby L, Versi E, Fenwick P, Studd JWW. Effect of oestrogen and testosterone implants on psychological disorders in the climacteric. Lancet 1984; 1 : 16-18

4 Slayden SM. Risks of menopausal androgen supplementation. Semin Reprod Endocrinol 1998; 16: 145-152

5 Marsden DE, Hacker NF. Optimal management of endometrial hyperplasia. Best practice and Research Clinical Obstet Gynaecol 2001; 15: 393-405

6 Lindahl B, Willen R. Steroid receptor concentrations as a prognostic factor in atypical endometrial hyperplasia. Anticancer Research 1998; 18: 3793-3795

7 Lindahl B, Alm P, Ferno M, Norgren A. Endometrial hyperplasia: a prospective randomised study of histopathology, tissue steroid receptors and plasma steroids after abrasio, with or without high dose gestagen treatment. Anticancer Research 1990; 10: $725 \cdot 730$

8 Masuzawa $\mathrm{H}$, Badokhon $\mathrm{NH}$, Nakayama $\mathrm{K}$ et al. Failure of down regulation of oestrogen receptors and progesterone receptors after medroxyprogesterone acetate administration for endometrial hyperplasias. Cancer 1994; 74: 2321-2328

9 Morsi HM, Leers MPG, Jager W, Bjorklund V, Radespiel-Troger M, El Kabarity H, Nap M, Lang N. The patterns of expression of an apoptosis-related CK 18 neoepitope, the $\mathrm{BCl}-2$ proto-oncogene, and the $\mathrm{Ki} 67$ proliferation marker in normal, hyperplastic, and malignant endometrium. Int J Gynecol Pathol 2000; 19: 118-126

10 Mattingly RF, Huang WY. Steroidogenesis of the menopausal and postmenopausal ovary. Am J Obstet Gynecol 1969; 103: 679-693

11 Thijssen JHH, Blankenstein MA. Endogenous oestrogens and androgens in normal and malignant endometrial and mammary tissues. Eur J Cancer Clin Oncol; 1989; 25: 1953-1959

12 Evans-Storms RB, Cidlowski JA. Regulation of apoptosis by steroid hormones. J Steroid Biochem Molec Biol 1995; 53: 1-8

13 Pollard IW, Pacey J, Cheng SVY, Jordan EG. Estrogens and cell death in murine uterine luminal epithelium. Cell Tissue Research 1987; 249: 533-540 
14 Sandow BA, West NB, Normal RL, Brenner RM. Hormonal control of apoptosis in hamster uterine luminal epithelium. Am J Anatomy 1979; 156: 15-36

15 Thompson EB. Apoptosis and steroid hormones. Molec Endocrin 1994: 6: 665-673

16 English HF, Kypraniou N, Isaacs JT. Relationship between DNA fragmentation and apoptosis in the programmed cell death in the rat prostate following castration. Prostate 1989; 15: 233-250

17 Poortman J, Thijssen JHH, van Landeghem AA, Wiegerinck MAHM, Alsbach GPJ. Subcellular distribution of androgens and oestrogens in target tissue. I Steroid Biochem 1983; 19: 939-945

18 Thijssen JHH, Daroszewski J, Milewicz A, Blankenstein MA. Local aromatase activity in human breast tissues. I Steroid Biochem Mol Biol 1993: 44: 577-582

19 Thijssen JHH, Blankenstein MA, Donker GH, Daroszewski J. Endogenous steroid hormones and local aromatase activity in the breast. I Steroid Biochem Mol Biol 1991; 39: 799-804

20 Van der Wall E, Donker TH, de Frankrijker E, Nortier HW, Thijssen JHH, Blankenstein MA. Inhibition of the in vivo conversion of androstenedione to estrone by the aromatase inhibitor vorozole in healthy postmenopausal women. Cancer Res 1993; 53: 4563-4566

21 Milde-Langosch K, Bamberger AM, Goemann C, Rossing E, Rieck G, Kelp B, Loning T. Expression of cell-cycle regulatory proteins in endometrial carcinomas: correlations with hormone receptor status and clinicopathologic parameters. I Cancer Res Clin Oncol 2001; 127: 537-544 
Chapter 10

\section{Summary}

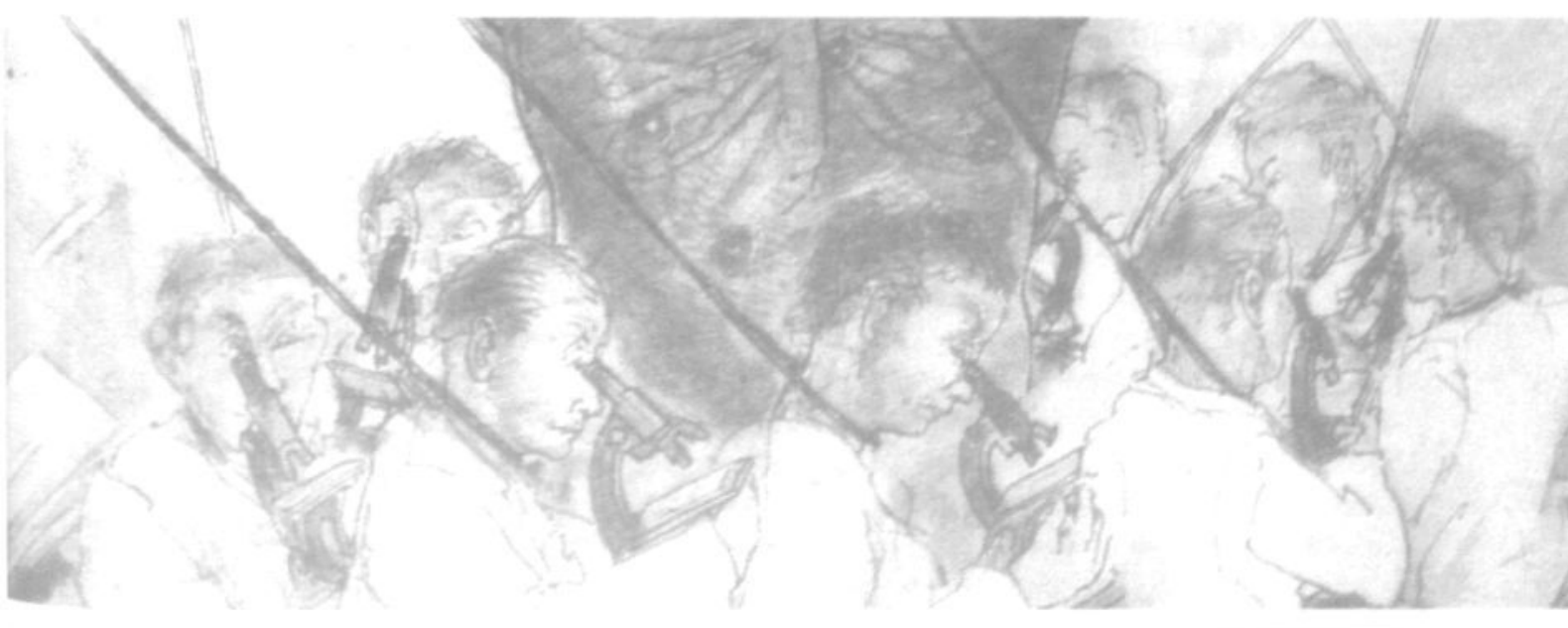




\section{Summary}

Morphological and biochemical changes in human endometrium are due to a sequence of proliferation, differentiation and cell death. They are supposed to reflect the biological function of the female genital tract, as influenced by steroid hormones. The aim of this thesis is to evaluate observations in premenopausal and postmenopausal benign and malignant endometrium, to gain insight into physiological cyclic changes of human endometrium and into postmenopausal physiologic and pathologic endometrial changes in relation with the steroid hormone concentrations.

In chapter 2, the distribution and intensity of immunohistochemical estrogen receptor (ER), progesterone receptor (PR) and androgen receptor (AR) staining were investigated in premenopausal patients with ovulatory menstrual cycles. The steroid hormone receptor staining was investigated in cavitary epithelium, in functional and basal endometrium, and in myometrium in the different menstrual cycle phases.

ER expression in glandular epithelial cells was persistently strong, decreasing from basal via functional endometrium to cavitary epithelium. ER expression in stromal and myometrial cells increased in the proliferative and significantly decreased in the secretory phases.

PR expression of glandular epithelial and functional stromal cells reached a maximum in the middle of the menstrual cycle. Basal stromal cells and myometrial cells show consistent staining, relatively weak in the first and stronger in the latter cells.

AR expression gradually decreased from the early to the late proliferative phase and continued to decrease in the early, mid and late secretory phases, more profound in stromal and myometrial than in glandular epithelial cells. In the late secretory phase there was no immunostaining for AR.

In chapter 3, a study is presented in which the distribution of immunohistochemical Bcl-2, an apoptosis inhibitor marker, and Ki67, a marker for proliferation, were investigated in endometrial glandular epithelium, in stromal cells and in myometrial cells. Bcl-2 and $\mathrm{Ki}_{7} 7$ expression were investigated in the different phases of the menstrual cycle of premenopausal patients.

$\mathrm{Bcl}-2$ expression increased in the proliferative phases and decreased in the secretory phases, especially in glandular epithelial cells. Staining of epithelial and stromal cells was more intense in basal than in functional endometrium or cavitary epithelium. Myometrial cells stained persistently and strongly.

Ki67 expression in glandular epithelial cells showed the same cyclic pattern as $\mathrm{Bcl}-2$ expression did, but at a later onset. In the late secretory phase, Ki67 immunostaining of epithelial cells was absent. No cyclic changes of Ki67 expression were seen in stromal or myometrial cells. Different responses on steroid hormone concentrations of glandular and stromal cells during the phases of the menstrual cycle, due to different growth-regulating-mechanisms, enable endometrial tissue to repair after menstruation. Our observations of $\mathrm{Bcl}-2$ and $\mathrm{Ki} 67$ expression in human endometrium, recognising mechanisms involved in physiologic hormone dependent tissue remodelling, suggest a role for these factors in tissue repair after menstruation and the subsequent development of a 'new' endometrium. 
Chapter 4 presents a study that evaluates different methods for steroid hormone receptor analyses in normal premenopausal and postmenopausal endometrium. Immunohistochemistry $(\mathrm{IH})$, used in chapter 2 and 3, preserves morphology and allows for steroid hormone receptor analysis in paraffin embedded tissue sections with the possibility of differentiation between epithelial and stromal cells in individual layers of the endometrium. Immunohistochemical analyses are time-consuming, partially subjective and for the greater part semiquantitative procedures. Single parameter or multiparameter flowcytometry (MP-FCM) represents an objective and fast single cell assay. A combined analysis with cytokeratin markers allows differentiation of epithelial cells from stromal or contaminating cells. Besides, with MPF, the steroid hormone receptor content can be investigated in relation to DNA ploidy and cell cycle parameters, as shown in chapter 7 and 8.

ER, PR and AR were analyzed in epithelial and stromal cells using IH and MPF. Both methods lead to comparable results for steroid hormone receptor expression. The Pearsons' correlation coefficient, as well as the intraclass correlation coefficient for ER, $P R$ and $A R$ confirmed the similarity of both methods of analyses. We concluded that the MP.FCM could replace the IH techniques for further research on behalf of its quantitativity, its multiparameter possibilities and its saving of time efforts.

That MPF can be helpful as a diagnostic procedure in clinical practice is shown in chapter 5. A patient who was known to suffer from endometrial cancer, which was limited to the endometrial cavity presented with clinically uncommon metastatic disease. Retrospectively, the patient was diagnosed as having two primary gynaecologic malignancies simultaneously. Besides a diploid epithelial tumor of the endometrium she suffered from an aneuploid epithelial tumor of the fallopian tube. The DNA-index of the malignant cells in her ascites was concordant with the DNA index of the tumor cells of the fallopian tube.

The development of endometrial cancer is known to be influenced by steroid hormones. In chapter 6, steroid hormone concentrations were investigated in postmenopausal patients with and without endometrial cancer, to determine the effect of postmenopausal (ovarian) steroid hormone production on the endometrium. Peripheral concentrations of estrone (E1), $17 \beta$-estradiol (E2), testosterone (T), androstenedione (A), sex hormone binding globuline (SHBG) and dehydroepiandrosterone sulphate (DHEAS) were not significantly different between patients with and patients without endometrial cancer, and neither were utero-ovarian vein concentrations of $E_{1}, E_{2}, A, S H B G$ and DHEAS. Pelvic levels of T were higher in patients with than in patients without endometrial cancer.

The potential effect of androgens on the aetiology of endometrial cancer may be direct, via interaction with the AR, or indirect, via local conversion into estrogens.

In chapter 7, a study is presented in which the steroid hormone receptor content was investigated in normal inactive postmenopausal endometrium, in hyperplastic endometrium and in endometrial cancer using MPF. In malignant endometrium, steroid receptor content and its heterogeneity were related to the DNA ploidy of the endometrial cells.

Overall, ER and PR content were not significantly different in benign versus malignant 
endometrial cells; AR content was higher in endometrial cancer than in benign endometrial cells. Endometrial hyperplasia and Grade I endometrial cancer show equivalent results for ER, PR and AR content and for the S-phase fraction; in normal inactive postmenopausal endometrium, ER, PR and AR content are lower than in hyperplastic endometrium. ER decreased from Grade I to Grade II endometrial cancer, as did PR; with further decreases in Grade III cancers. In contrast to ER and PR content, AR content increased, the more so as normal morphologic tissue characteristics disappeared.

The percentages of aneuploid tumors were higher in Grade II and Grade III versus Grade I endometrial cancers; the S-phase fractions increased. In tumors that are aneuploid, the ER, PR and AR contents in the diploid tumor fractions were higher as compared to the same steroid hormone receptor contents in the aneuploid tumor fractions. The S-phase fractions were higher in the aneuploid than in the diploid tumor fractions.

Endometrial hyperplasias are known to carry a risk for progression to endometrial cancer. The morphologic subclassification of endometrial hyperplasias with its inherent subjectivity is not reproducible. The present study showed no differences for the investigated parameters in the subgroups of hyperplasia and Grade I endometrial cancer. Besides, it was concluded that steroid hormone receptor content, DNA ploidy and the S-phase fraction are objective parameters useful as diagnostic tools. Because nowadays, clinicians try to finalise the diagnosis with only small endometrial tissue samples, such objective cell parameters, reliably obtainable also in case of limited tissue availability may add in clinical practice.

Chapter 8 presents a study of the endometrial tissue expression of the monoclonal antibody $M_{3}$, which is a marker for apoptosis, and $M_{3} 0$ levels in peripheral and pelvic serum samples in postmenopausal women. Apoptosis plays a crucial role in carcinogenesis. In benign and malignant endometrium, $\mathrm{M}_{30}$ expression in endometrial tissue and $M_{30}$ serum levels were correlated with the S-phase fractions of the tumor. Local $M_{30}$ serum levels and tissue $M_{30}$ content were higher in patients with than in patients without endometrial cancer; both parameters increased from inactive to hyperplastic endometrium, and further to Grade I, Grade II and to Grade III endometrial cancer. Also the S-phase fraction was higher in endometrial cancer than in benign endometrial cells. Irrespective of the Grade of tumor, the S-phase fractions of the aneuploid tumor fractions were higher than the diploid tumor fractions.

The study focussed on patients with endometrial cancer, Figo stage IB. If the level of apoptosis is correlated with the progression of endometrial cancer, levels of $M_{3} 0$ levels could be used in clinical practice to differentiate a subgroup of patients with endometrial cancer Figo stage IB, who will benefit from adjuvant radiotherapy. 


\section{Samenvatting}

Humaan endometrium is onderhevig aan vele hormonale, histomorphologische en biochemische veranderingen gedurende de menstruele cyclus. Zo zijn proliferatie, differentiatie en apoptose (natuurlijke celdood) herkenbaar in normaal cyclisch endometrium. Ze weerspiegelen de functie van de vrouwelijk voortplantingsorganen. Behoudens de invloed van oestrogenen en progesteron bleken ook androgenen effect te hebben op het endometrium. Doel van dit onderzoek is het inzicht te vergroten in fysiologische en pathologische processen van endometrium door het observeren van veranderingen gedurende de menstruele cyclus en na de menopauze.

In hoofdstuk 2 werden de resultaten gepresenteerd van onderzoek naar de aanwezigheid van de oestrogeenreceptor (ER), de progesteronreceptor (PR) en de androgeenreceptor (AR) in cyclisch endometrium van 30 gezonde patiènten. Met behulp van immunohistochemie kon de cyclische variatie van de expressie van steroidhormoonreceptoren worden bepaald in de onderscheiden lagen van het endometrium, te weten in de oppervlaktelaag van epitheliale cellen, in de functionele laag met epitheliale en stromale cellen, in de basale laag met epitheliale en stromale cellen, en in het myometrium.

De ER kwam met name tot expressie in epitheliale cellen, afnemend van basaal via functioneel endometrium naar het oppervlakte-epitheel. ER-expressie was hoog in de proliferatiefase en relatief laag in de secretiefase. De ER-expressie van stromale en myometrium cellen toonde nagenoeg dezelfde cyclische variatie; in stromale cellen van de lamina basalis was de expressie hoger dan in de stromale cellen van de lamina functionalis.

De PR-expressie van de epitheliale cellen nam toe vanaf het oppervlakte-epitheel via de lamina functionalis naar de lamina basalis. Tot halverwege de secretiefase was er een toename; in de luteale fase, na toename van de serumconcentratie progesteron, nam de expressie af. In de stromale cellen en in het myometrium was de PR-expressie nagenoeg constant.

In tegenstelling tot de ER- en PR-expressie was de AR-expressie relatief gering. Bovendien was de expressie in stromale cellen nadrukkelijker aanwezig dan in epitheliale cellen. De expressie was hoog in de vroege proliferatiefase en daalde geleidelijk gedurende de menstruele cyclus. In laat secretoir endometrium werd geen expressie van AR meer aangetoond. De cyclische variatie van de AR-expressie kan, net als in prostaatweefsel, onder invloed staan van androgenen. Daarnaast is het mogelijk dat, als de AR-expressie in het endometrium net als in prostaatweefsel afhankelijk is van dihydrotestosteron, een afname van de concentratie dihydrotestosteron (ten gevolge van een verhoogde progesteronconcentratie) leidt tot een verminderde AR. expressie.

In hoofdstuk 3 werden de expressie van $\mathrm{Bcl}-2$, een anti-apoptosemarker, en de expressie van Ki67, een proliferatiemarker, beschreven in het endometrium van 30 premenopauzale patiënten. Wederom werd onderscheid gemaakt in de diverse cyclusfasen en werden lagen van het endometrium en het myometrium onderscheiden.

Bcl-2-expressie nam toe in de proliferatiefase en nam weer af in de secretiefase, met 
name in de epitheliale cellen. De epitheliale en stromale cellen toonden meer expressie van $\mathrm{Bcl}-2$ in de lamina basalis dan in de lamina functionalis. De expressie in het myometrium was constant hoog.

De expressie van Ki67 in epitheliale cellen toonde dezelfde cyclische variatie als de $\mathrm{Bcl}$-2-expressie. Laat secretoir kwam geen $\mathrm{Ki}_{7}$ tot expressie. De Ki67-expressie in stromale cellen en myometrium toonde geen cyclische variatie.

Bij de opbouw van het endometrium na de menstruatie lijken apoptose en proliferatie een rol te spelen, welk idee wordt ondersteund door de verschillende reacties van epitheel en stroma op de hormonale beïnvloeding.

In Hoofdstuk 4 werden de resultaten van een studie gepresenteerd waarin de steroidhormoonreceptoren in het endometrium zijn bepaald met behulp van twee verschillende onderzoeksmethoden. Het voordeel van de veel gebruikte immunohistochemie is met name het behoud van de histomorphologie, zodat de steroidhormoonreceptorexpressie kan worden bepaald per individuele laag van het endometrium. Single- of multiparameter flowcytometrie daarentegen biedt de mogelijkheid de steroidhormoonreceptorexpressie in endometrium objectief te meten in een kort tijdbestek. De combinatie met bijvoorbeeld cytokeratines maakt het mogelijk om de epitheliale component van de stromale component van het weefsel te onderscheiden, zodat de steroidhormoonreceptorexpressie separaat in beide celtypen kan worden berekend. De ER, PR en AR waren aantoonbaar in alle lagen van het endometrium. De steroidhormoonreceptorstatus kende een cyclische variatie. Uit de studie bleek dat de immunohistochemische methode voor het bepalen van de steroidhormoonreceptorexpressie in humaan endometrium vervangen kan worden door de flowcytometrische bepalingsmethode met behoud van de kwaliteit van de meting.

In hoofdstuk 5 werd een patiënte met een gynaecologische dubbeltumor beschreven. Via flowcytometrie kon retrospectief de juiste diagnose worden gesteld bij een patiënte van wie werd verondersteld dat ze een endometriumcarcinoom had. Door een ongewone klinische presentatie van haar ziekte werd de oorspronkelijke diagnose heroverwogen. Via flowcytometrische bepaling van de DNA-ploidy bleek de patiënte behoudens aan een endometriumcarcinoom ook aan een tubacarcinoom te lijden. De metastasen waren afkomstig van het primaire tubacarcinoom.

In hoofdstuk 6 werden de steroidhormoonconcentraties beschreven bij 109 patiënten met en zonder een endometriumcarcinoom om zo de relatie tussen de steroiden en het ontstaan en de ontwikkeling van het endometriumcarcinoom te onderzoeken. Bloed werd afgenomen uit een perifere vene en uit de ufero-ovariële plexus.

Er bleek nauwelijks verschil in $17 \beta$-oestradiol, oestron, het sex hormoon bindend globuline of dihydroepiandrosteron in perifeer of locaal serum tussen patiënten met en zonder endometrium carcinoom. Bovendien was er nauwelijks verschil in deze concentraties tussen het perifere en het locale bloedmonster. Het serum testosterongehalte daarentegen was significant hoger in het locaal serummonster van patiënten met een endometriumcarcinoom dan in locaal serummonster van patiënten zonder endometriumcarcinoom. Bovendien bleken de locale concentraties van testosteron en androsteendion significant hoger dan de perifere concentraties. 
Er bestaat mogelijk een direct (via interactie met de AR) of indirect effect van androgenen (via locale omzetting in oestrogenen) op het ontstaan van het endometriumcarcinoom.

De hormoon-receptorbinding is een vereiste voor de hormoonwerking en dus voor de celfunctie. In hoofdstuk 7 werden de resultaten gepresenteerd van een onderzoek naar de ER, PR en AR, bepaald met behulp van multiparameter flowcytometrie bij 13 patiënten met normaal postmenopauzaal endometrium, bij 4 patiënten met endometriumhyperplasie, bij 5 patiënten met atypische endometriumhyperplasie en bij 35 patiënten met een endometriumcarcinoom. In het endometriumcarcinoom werden de heterogeniteit en de steroidhormoonreceptorstatus bepaald in relatie tot de DNA-ploidy.

$E R$ en PR waren niet verschillend in benigne of maligne endometrium; AR was significant hoger in het endometriumcarcinoom. De steroidhormoonreceptorstatus en de S-fase fractie (een proliferatiemarker) waren nagenoeg gelijk in zowel hyperplastisch endometrium met en zonder atypie als in het goed gedifferentieerde endometriumcarcinoom; in normaal postmenopauzaal endometrium waren de ER, PR en $A R$ geringer. De ER en PR namen af. De AR en de S-fase fractie namen toe van graad I via graad II naar graad III endometriumcarcinoom. Het percentage aneuploïde tumoren was laag in goed gedifferentieerde endometriumcarcinomen en nam toe via matig naar slecht gedifferentieerde tumoren. In de diploïde fracties van de aneuploïde tumoren waren de ER, PR en AR hoger en de S-fase fractie lager dan in de aneuploïde fracties.

Endometriumhyperplasie (een hyperoestrogene status) is een mogelijk risico voor het ontwikkelen van een endometriumcarcinoom. De histomorfologische diagnose van endometriumhyperplasie met of zonder atypie of van het goed gedifferentieerde endometriumcarcinoom bleek niet reproduceerbaar en consequent, zelfs niet bij beoordeling door gerenommeerde pathologen. De ER, PR, AR en S-fase fractie bleken binnen deze drie subgroepen van endometriumafwijkingen nauwelijks verschillend. Wel kunnen deze parameters worden gebruikt om te differentiëren tussen graad I, graad II en graad III carcinomen. Aangezien gepoogd wordt de juiste diagnose snel en weinig invasief te stellen kan een objectieve bepaling van deze parameters door middel van de beschreven technieken bijdragen aan de diagnostiek in de dagelijkse praktijk.

Hoofdstuk 8 betrof een studie naar de klinische toepassing van proliferatie- en apoptosemarkers in humaan endometrium. De apoptosemarker $\mathrm{M}_{3}$, welke een neoepitoop van cytokeratine 18 herkent, en de S-fase fractie werden bepaald in endometrium van 112 patiënten. $\mathrm{Er}$ werd onderscheid gemaakt in normaal postmenopauzaal endometrium, in hyperplastisch endometrium en in het endometriumcarcinoom. Bovendien werd de $M_{30}$ bepaald in het serum van een perifere vene en van de utero-ovariële plexus van patiënten met of zonder endometriumcarcinoom.

Zowel in het serum van de utero-ovariële plexus als in het endometrium bleek $\mathrm{M}_{30}$ hoger bij patiënten met dan bij patiënten zonder een endometriumcarcinoom. Er was een toename van normaal naar hyperplastisch endometrium en een verdere toename van graad I via graad II naar graad III endometriumcarcinomen. Ook de S-fase fractie 
was hoger in endometriumcarcinoom dan in benigne endometrium.

Als de mate van apoptose gerelateerd is aan de progressie van de ziekte, zou uitbreiding van de diagnostiek met bepaling van de apoptose markers kunnen bijdragen aan de besluitvorming van behandeling van patiënten met een endometriumcarcinoom. 


\section{Dankwoord}

Professor dr. Evers, Professor, de drempel van uw kamer wisselde in hoogte; dit in tegenstelling tot uw stiptheid. Mijn waardering, mijn dank en herinnering aan de kansen die ik kreeg dit onderzoek samen met u te volbrengen zullen blijven. $U$ bleef een belangrijke stimulans het onderzoek goed te doen. Elk detail werd met een onbegrijpelijke snelheid onderkend. Dank voor uw kritiek en uw enorme inzet voor en begeleiding bij mijn promotie. Ook als opleider wist u richting te geven aan mijn werk als gynaecologe. Dank, voor alles.

Professor dr. Heineman, beste Maas-Jan, ondanks uw vertrek uit het zuiden hebt u de voortgang van mijn promotie verzekerd. Het initiatief is uw eigendom. Uw stroom van post en emailtjes en uw standvastigheid zorgden ervoor dat elk hoofdstuk werd vervolmaakt. Dank voor de mogelijkheid tot deelname aan uw 'Aging Ovaries'. Dat mijn eigen 'ovaries' intussen zo zouden 'agen' had u niet voorzien. Dank voor alle stimuli, voor uw continue zorg en uw belangstelling voor mij en het project. Dank, voor alles.

Dr. Nap, Marius, je hebt mij ingewijd in de klinische toepassingen van de multiparameter flowcytometry. lij bracht kliniek en wetenschap bijeen, maar accentueerde ook de verschillen. Dank voor je inzet en bijdrage aan mijn promotie. Met jou als copromotor wil ik ook mijn speciale dank uitspreken aan je collega's. Dr. Koudstaal als mede-initiator van de eerste helft, dank voor het herbeoordelen van de paraffine coupes. Dr. Theunissen, beste Paul, jij hebt het gehele onderzoek op de achtergrond mee beleefd. Dank voor je medewerking en belangstelling. Dr. Verdonck, dank voor het beschikbaar stellen van uw microscoop tijdens mijn nachtdiensten in het ziekenhuis in Brunssum.

Dr. ing. Leers, beste Mathie, jouw bijdrage was van onschatbare waarde. Jouw hulp, je inzet, adviezen en enthousiasme lopen als een rode draad door mijn onderzoek heen. Zonder jouw bijdrage had het onderzoek zich anders ontwikkeld. Dank dat ik altijd op je kon rekenen. Ik ben er trots op dat je zelfs vandaag als rechterhand naast me staat.

Drs. Mulder, beste Robertjan, je hebt de weg naar promotie vaak onderschat, of mij overschat. Maar je hebt gelijk gekregen, het boekje is af. Dank voor je voortdurend vertrouwen. De combinatie van het endometriumonderzoek en de gynaecologische praktijk laat zich het best vertalen in de keuze van mijn twee paranimfen. Van jouw bijdrage aan de start en het vervolg van mijn carrière als gynaecoloog heb ik nog dagelijks profijt. Dank voor al je aanmoedigingen en je aanwezigheid op deze bijzondere dag.

De leden van de beoordelingscommissie, Prof. dr. M.F. von Meyenfeldt, Prof. dr. Aalders, Prof. dr. Daemen, Prof. dr. Kieback en Prof. dr. Thijssen wil ik hartelijk bedanken voor de moeite die zij genomen hebben het manuscript te beoordelen. 
De leden van de Heerlense maatschap gynaecologie ben ik allen dank verschuldigd. De start van mijn promotie en mijn opleiding gynaecologie in uw ziekenhuis maken de herinneringen aan een heel plezierige tijd in uw kliniek blijvend. Een aantal gynaecologen zou ik, zonder anderen tekort te willen doen, graag met naam noemen. Dr. Stoot, als onberispelijke, hard werkende, menselijke dokter en opleider heb ik veel van u geleerd. Dank voor de mogelijkheid om mijn opleiding te combineren met het endometriumonderzoek. Dank ook voor uw warme belangstelling en uw inzet op cruciale momenten tijdens het onderzoek. Drs. Zandvoort, ondanks uw relativeren van het belang van wetenschap toonde $u$ altijd belangstelling en werd ik menigmaal uitgenodigd de bevindingen toe te lichten. Dank voor uw klinische lessen en het lenen van uw microscoop. Drs. Degen en dr. Salemans, Jeroen en Tom, samen staan jullie aan de basis van mijn keuze voor de gynaecologie. Jullie hadden het goed doorzien. Dank voor de goede tijd in Brunssum en de plezierige samenwerking in het Heerlense.

Prof. dr. De Jong, dank voor uw kritische bijdrage en serumbepalingen in uw laboratorium in Rotterdam. Dank ook aan de medewerkers van de laboratoria in Rotterdam en Heerlen voor alle opslag en bewerkingen van het patiëntenmateriaal.

Dr. ir. Patrick Groothuis, als steun en toeverlaat voor de gehele endometriumendometriosegroep, bracht je ook voor mij een oplossing. Dank voor al je support en de prettige samenwerking. Natasja Kisters, dank voor je werk achter de flowcytometer in Heerlen. Dr. Gerard Dunselman, dr. Ton de Goeij, Annemiek, Jacques, Hanny en alle andere leden, dank voor de mogelijkheid deel te nemen aan jullie florerende onderzoeksgroep.

Mijn collega 's assistent gynaecologen, gynaecologen, medewerkers van het secretariaat gynaecologie in Brunssum, Heerlen en Maastricht, medewerkers van het secretariaat pathologie in Heerlen, mijn familie, vriendinnen en vrienden dank ik allen voor hun persoonlijke bijdrage aan mijn opleiding en promotie. Petra en Trudy, een speciaal woord van dank voor jullie secretariële ondersteuning.

Mijn nieuwe maten gynaecologen dank ik voor mijn warme welkom in Sittard. Dank voor jullie vertrouwen. Ik reken op een lange en plezierige samenwerking!

Mijn ouders, lieve papa en mama, u beiden hebben mij altijd onvoorwaardelijk met liefde ondersteund. Gezien mijn hang naar vrijheid ben ik beslist een moeilijke dochter. Dank voor al jullie raad, jullie begrip, de kliekjes, autowasbeurten, correcties en noem maar op. Ik hoop dat jullie nog lang in goede gezondheid getuige moge zijn van rustigere en evenwichtigere levensmomenten. 


\section{Curriculum Vitae}

Helena Josephina Maria Mathea Mertens werd op 16 april 1969 in Heerlen geboren. Na het voltooien van het Gymnasium $\beta$ aan het St.Janscollege in Hoensbroek startte Helen in 1988 de studie Medicijnen aan de Rijksuniversiteit Limburg in Maastricht. Haar studie werd tweemaal tijdelijk in het buitenland voortgezet; eerst in het Sint Maarten Medical Center in Philipsburg, de Nederlandse Antillen (1991), later in The National Cancer Institute in Washington DC, Amerika (1993/1994). Na het artsexamen in 1995 werkte zij als Assistent Geneeskundige Niet in Opleiding op de afdeling gynaecologie van het toenmalige St.-Gregorius-ziekenhuis in Brunssum. Van april 1996 tot april 2002 werd zij opgeleid tot gynaecoloog; tot 2000 in het voormalig De Weverziekenhuis in Heerlen (opleider dr. J.E.G.M. Stoot) en vervolgens in het Academisch Ziekenhuis in Maastricht (opleider Prof. dr. J.L.H. Evers). In 2000 werd zij Clinicus van het Jaar, Artsen Academisch Ziekenhuis. Haar klinische opleiding wist Helen te combineren met haar promotieonderzoek (begeleiders Prof. dr. J.L.H. Evers en Prof. dr. M.J. Heineman). Sedert april 2002 is zij werkzaam als gynaecoloog in het Maaslandziekenhuis in Sittard. Haar interesse gaat met name uit naar de gynaecologische oncologie. 
$\bar{P}$ 

